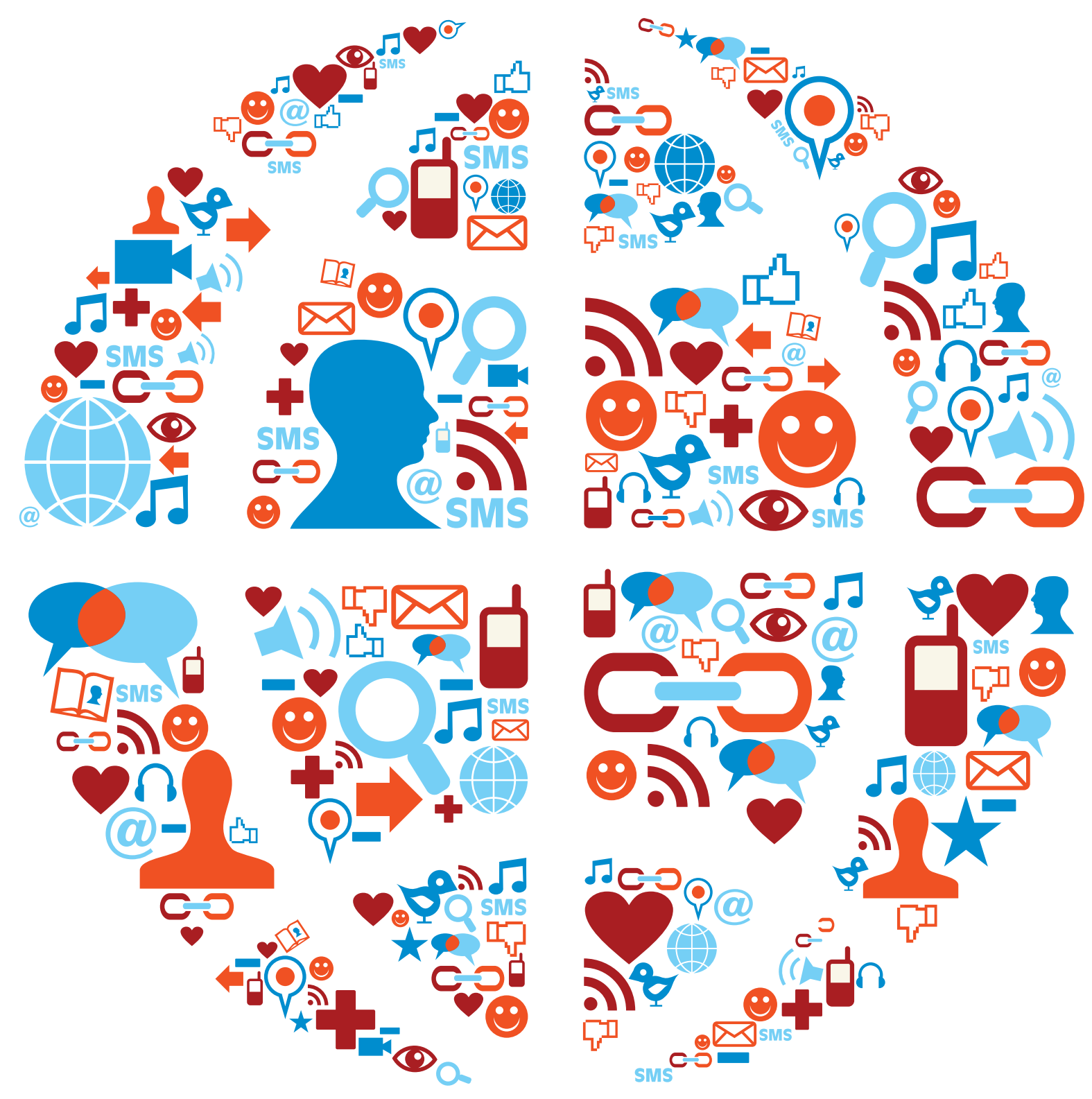

Ethnologia Europaea Journal of European Ethnology

Special issue: Imagined Families in Mobile Worlds

42:2 2012 


\section{Ethnologia Europaea}

Journal of European Ethnology

Editors Orvar Löfgren and Regina Bendix

Editorial assistant

Magdalena Tellenbach Uttman

Editorial board Pertti Anttonen (Finland), Milena Benovska-Sabkova (Bulgaria), Reginald Byron (UK), Palle O. Christiansen (Denmark), Hester Dibbits (Netherlands), Manuela Ivone Cunha (Portugal), Tine Damsholt (Denmark), Anne Eriksen (Norway), Jonas Frykman (Sweden), Ueli Gyr (Switzerland), Ewa Klekot (Poland), Ullrich Kockel (UK), Ruth-E. Mohrmann (Germany), Bjarne Rogan (Norway), Thomas Schippers (France), Martine Segalen (France), Birgitta Svensson (Sweden), Gisela Welz (Germany)

$\begin{aligned} \text { Addresses } & \text { Professor Orvar Löfgren } \\ \text { for manuscripts } & \text { Department of Cultural Sciences } \\ & \text { Biskopsgatan } 7 \\ & \text { SE-223 } 62 \text { Lund, Sweden } \\ & \text { Phone }+46462220458 \text { Fax }+46462224205 \\ & \text { E-mail orvar.lofgren@kultur.lu.se } \\ & \text { Professor Regina Bendix } \\ & \text { Institut für Kulturanthropologie/Europäische Ethnologie } \\ & \text { Humboldtallee } 19 \\ & \text { D-37073 Göttingen, Germany } \\ & \text { Phone +49 551 3953 51 Fax +49 551 39 22 } 32 \\ & \text { E-mail rbendix@gwdg.de } \\ & \\ & \text { Magdalena Tellenbach Uttman, Ph.D. } \\ & \text { Järnvägsgatan } 16 \\ & \text { SE-241 72 Marieholm, Sweden } \\ & \text { E-mail magdalena.tellenbach@uttman.com }\end{aligned}$

For prices and subscription details please see www.mtp.dk

Subscription address Museum Tusculanum Press

University of Copenhagen

Birketinget 6

DK-2300 Copenhagen, Denmark

Phone +45 35329109 Fax +4535329113

E-mail order@mtp.dk Internet www.mtp.dk

Bank IBAN: DK 9830000005252520

BIC: DABADKKK 


\section{Ethnologia}

Europaea

\section{eJournal of European Ethnology}

Volume 42:2

2013

Guest editors: Karen Körber

and Ina Merkel 
Ethnologia Europaea

eJournal of European Ethnology 42:2

Copyright (๑) Museum Tusculanum Press 2013

ISBN 9788763541145

ISSN 16043030

\section{Unaltered version in pdf-format of:}

Copyright $(\odot 2012$

Printed

Cover and layout

Cover illustration
Ethnologia Europaea, Copenhagen

in Sweden by Exactaprinting AB, Malmö 2013

Pernille Sys Hansen

(C) iStockphoto/Cienpies Design

ISBN 9788763540445

ISSN 04254597

This journal is published with the support of the Nordic board for periodicals in the humanities and social sciences.

Museum Tusculanum Press

University of Copenhagen

Njalsgade 126

DK-2300 Copenhagen S

www.mtp.dk 


\section{CONTENTS}

Karen Körber and Ina Merkel

Imagined Families in Mobile Worlds. An Introduction

5

Karen Körber

So Far and yet so Near. Present-Day Transnational Families

Gertrud Hüwelmeier

"The Daughters Have Grown Up". Transnational Motherhood, Migration and Gender among Catholic Nuns 26

Elisabeth Timm

Grounding the Family. Locality and its Discontents in Popular Genealogy

Sabine Hess

How Gendered Is the European Migration Regime? A Feminist Analysis of the

Anti-Trafficking Apparatus

51

Magdalena Radkowska-Walkowicz

Who Is Afraid of Frankenstein? Polish Debate on In-Vitro Fertilization

69

\section{Comments $\quad 85$}

Marie Sandberg

Karol's Kingdom 87

Beatriz Lindqvist

From Accompanying Family Member to Active Subject. Critical Perspectives on Transnational Migration $\quad 94$

Karin Lützen

Immigration - and Secrets 100

Laura Stark

The Materiality of the Imagined Family

103 


\title{
IMAGINED FAMILIES IN MOBILE WORLDS An Introduction
}

\author{
Karen Körber and Ina Merkel
}

Families "on the move", "Euro-orphans", and "transnational mothers" - more than ever before, talk about the family is permeated with the opportunities and challenges currently presented by an increasing, border-crossing mobility. ${ }^{1}$ A glance at European press and media coverage shows that the family has recently become an object of public attention, and one that seems to indicate primarily a state of crisis. For several years now, newspaper articles and TV documentaries have been reporting on women who take on housework and caring tasks in Western European dual-earner households, precariously employed as nannies and maids while their children are left behind in the depleted villages of Poland, Ukraine, and Moldavia as the "silent" victims of westward labour migration. This seems to continue, in a kind of distorting mirror, the trend diagnosed by US sociologist Richard Sennett as early as the 1990s. Sennett saw a new capitalism generating the values of a flexible society, whose most important dictum - "keep moving, don't commit yourself, and don't sacrifice" (1998: 25) - placed massive pressure on the institution of the family. These representations of feminized labour migration from East to West, South to North, reveal a new dimension of social inequality in global capitalism, but they also document a transformation in the gender order, at the symbolic heart of which stand contested images and discourses about "the" family.

The hypothesis of a crisis of the family has been refuted in past years primarily by numerous migra- tion researchers, investigating the family within the domain that has been chiefly blamed for its decline (Lima 2001; Bryceson \& Vuorela 2002; Sørensen \& Guarnizo 2007). The global increase in migratory movements and altered or newly emerging patterns of migration and mobility have resulted in radical change to the perspectives of migration studies itself. Such research no longer revolves around the notion of linear, one-off, and completed migration processes from a society of origin to a receiving society; instead, the focus is on the complex, often largely stable and long-lived, "transnational" relationships between people, networks, and organizations across the borders of the nation state (Basch, Glick Schiller \& Szanton Blanc 1994; Pries 2001; Vertovec 2009). In this context, the rise of the "transnational family" enhances the importance of a form of life that at first sight seems to embody a paradox: despite geographical distance and the experience of dispersal, the very social group whose core elements include spatial proximity and direct community is capable of sustaining the family virtually as its principal point of orientation and reference. As such, it is proving both resistant and creative in the face of the new demands of globalized societies.

This special issue critically addresses not only the prophecies of the end of the family, but also the apparent paradox inherent to the new models of familiarity under conditions of increased mobility. While working from very different angles, all the contributions join in querying a concept of fam- 
ily that makes the autochthonous family, located within national boundaries, the yardstick for all others. The Euro-American definition of family as a nuclear family characterized by settledness and geographically proximal relationships is here regarded as an articulation of "methodological nationalism" (Beck 2003) that obscures the cross-border practices constitutive for many different mobile and transnational family forms both past and present. Tracing the challenges, the creative potential, the cultural practices, and equally the constraints, of multi-locality for the meaning of family, our approach begins from a question that was raised in an earlier special issue of Ethnologia Europaea, "Double Homes, Double Lives?” (Bendix \& Löfgren 2007): How do identity and feelings of belonging change under the conditions of dual location? Like that special issue, the present collection also pursues European ethnology's concern to address mobility and migration processes through both biographically oriented, ethnographic studies and the analysis of cultural, symbolic, and discursive practices. However, the authors of these five contributions do not attempt to reach a single position on the notion of the family; rather, by interlocking ethnographic and discourse-analytical methods and combining them with gender theory, they share a focus on the technologies, genealogies, policies, and regulations that participate crucially in the construction of family, gender, and bodies.

\section{Imagined Family - How Family Is Made}

In the organization of social interaction and the constitution of individuals, family and kinship are of prime significance across all cultures and epochs. That does not appear to have changed fundamentally in the socially differentiated, mobile, and globalized societies of late modernity. As the key orders of the social, and those with the greatest impact in everyday life, family and kinship constitute more than a formal classificatory system of social relationships and an order-endowing structure in the world's cultures: in Pierre Bourdieu's terms, they are "structuring structures", in other words "principles of the generation and structuring" of repre- sentations, practices, identities, and social forms (Bourdieu 1977: 72).

Against this background, our title, "Imagined Families", follows authors such as Deborah Bryceson and Ulla Vuorela (2002) in transposing Benedict Anderson's thesis of nationalism as imagined community (1983) onto the family, and thus directing attention to the ways that family is made: how it is negotiated, symbolically generated, and affirmed through everyday practice, but also how it is changed, for example through altered legal frameworks. In Euro-American societies, the order of the family has always been conceived of as something dual, both biological and social (König 1974: 61), and as centred on filiation and heterosexuality. The past few decades have seen numerous challenges to this understanding of family and kinship, which legitimizes and privileges consanguinity over other forms of long-term bonds and care and naturalizes the distinction between "natural" and "other" kinship. More recent thinking in kinship ethnology also reflects social transformations - especially altered gender relations, pluralized family formations, and the cultural consequences of migration and globalization, but also biotechnological developments such as reproductive medicine. Thus, current models of kinship emphasize the ways that family relationships are produced, revised, and lived within actual social processes (Carsten 2000; Faubion 2001). In her work on adoption practices, Signe Howell (2001) introduces the notion of "kinning", thus giving linguistic form to the processual and active character of "making kin". Similarly, the studies published by Beck et al. (2007) use the examples of transnational adoption and assisted reproductive technologies to show that the opposition between "natural" and "made" kin relationships is inexistent: instead, kinship is always and everywhere produced as a social form.

That "kin relationships are something that people make, and with which they do something" (Bourdieu 1990: 167) is also among the principal assumptions informing the contributions by Karen Körber, Gertrud Hüwelmeier, and Elisabeth Timm. All three authors are concerned, in differing ways, 
with present-day and historical dimensions of transnational familiarity; it is in this setting that they examine the constrictions and pitfalls of a EuroAmerican notion of family. Körber and Hüwelmeier pick up on current discussions around the relationship of gender, transnationalism, and family. On the one hand, they pursue an analytical perspective set out by Sarah Mahler and Patricia Pessar, focusing on a "gendered geography of power" (2001: 441) that aims to open up our awareness that "gender operates simultaneously on multiple spatial and social scales (e.g. the body, the family, the state) across transnational terrains" (ibid.: 445). On the other, they draw on studies that concentrate less on the material ties of reciprocal obligation in transnational families than on the cultural practices within and by means of which family attachments are experienced and moulded across time and space (Vuorela 2002; Baldassar, Baldock \& Wilding 2007). Thus, Mary Chamberlain and Selma Leydesdorff (2004: 227-228) trace the special significance accorded to "memories and narratives" in diasporically dispersed families, as ways of enabling a shared understanding of family in circumstances of separation. Describing women's attempts to keep families living in separation physically and emotionally intact, Pierette HondagneuSotelo and Ernestine Avila refer to transnational "circuits of affection, caring, and financial support" (1997: 550) - thereby naming the key dimensions addressed by numerous studies in recent years. All these investigations concur in relating the question of new forms and practices of familiarity to that of reconfigured gender relations in transnational families. Bridget Anderson (2001) and Aihwa Ong (1999), for example, both stress that an analysis of transnational social spaces cannot be restricted to the practices of the state, but must also address the politics of the body, the regulation of the private sphere and of family circumstances, and culturally hegemonic gender norms and discourses in both the sending and the receiving country (see also Hess and Radkowska-Walkowicz in this issue).

Karen Körber's contribution picks up on these debates. Through family biography interviews, she shows how transnational families use new commu- nication technologies to produce familiarity across great distances and long periods of time. Two selected case studies of families, taken from European labour migrations of the 1960s and post-1990, reveal how the transformation of time-space organizational patterns can create a virtual proximity at a distance, enabling geographically fragmented families to forge new practices and forms of everyday togetherness that may endure for many years. This highlights the limits of a notion of family founded on spatial proximity and direct community, while also demonstrating that access to and use of new technologies is not something neutral, but is structured by relations of social inequality that unfold their specific effects in the context of migration regimes. In the European order of migration, an increasing feminization of migratory movements can be observed, the routes and practices of which are being progressively illegalized. This restrictive European policy has far-reaching consequences for the relationship between gender and family in transnational family configurations.

Giving a voice not only to the agents of migration themselves, but also to the "immobile" family members left behind, Körber's study identifies how both sides actively participate in sustaining transnational social and symbolic ties in the course of familial exchange processes. Transnational familiarity, the article shows, encompasses not only the relationship between adolescents and their parents, but more widely the lifelong relationship between people of different generations, which changes and redefines itself across the family's lifetime.

This observation connects Körber's study to Gertrud Hüwelmeier's. Hüwelmeier addresses the currently much-debated concept of transnational motherhood, but casts interesting new light on it from a historical and anthropological viewpoint: she investigates not biologically generated families, but kinship that is grounded in ritual in the framework of transnational women's congregations. Using multi-sited fieldwork, she traces the transformation of these relationships over time and space, showing that familial relations transcending national borders are not something new - in the past, without today's 
technological resources, it was already possible to maintain emotional presence and participation at a distance. In line with other historical studies of gender-specific practices of migration (Harasser 1996; Harzig 1997; Henkes 1998), Hüwelmeier's paper indicates that nuns, those "pioneers of female migration", were moving along transnational routes in the nineteenth century. Her research on the relationships of mother superiors to their daughters or "sisters" also refers to ethnographic studies of co-parenting. As well as revealing the ethnocentric narrowness of the Euro-American concept of family, this comparison underlines once more the inherently constructed character of "kinship" as a social form.

If Körber and Hüwelmeier query the notion of family as a biologically grounded and proximate social group, Elisabeth Timm tracks a further implicit norm of the Euro-American family. Her historically based study of popular genealogies, using the example of Austria, investigates a "cultural norm of settledness" (Merkel 2002: 233) that she finds inscribed in the genealogical practice of searching for, and constructing, family. Working from a micro perspective, she analyses the production of settledness through the case of Austrian parish registers, the Matriken. A focus on three moments, reaching from the Reformation via the interwar period into the digital present, shows how the fact of migration and mobility is negated across time and how the identification of "being kin" with "being there" has to be continually produced afresh. Timm traces how the process of grounding the family as the nucleus of the state and society has gone hand in hand with the process of localizing it and making it settled; against this, she posits the relational complementarity of mobility and immobility. As in Hüwelmeier's contribution, it again becomes obvious that transnationality is not a new phenomenon in historical terms. Timm's study contributes to a debate also found, in a different form, in Körber's: whether the opposition between mobile and immobile actors and ways of life does not itself obey an artificial binarism incapable of standing up to empirical examination.

\section{Mobility, Gender, and Family - Policies, Regulations, and Technologies}

The assumption of a settled, biologically grounded family based on experiences of intimacy and care is inextricable from notions of family and gender. Recent scholarship has often asked how far present-day transnational mobilities are changing family configurations in a gender-specific way. The gender significance of this question has also grown in that the narrative of mobility no longer takes concrete shape in the figure of the male breadwinner: women are now the ones on the move. Although women's migration is no historical innovation, as Hüwelmeier's contribution shows, the feminization of migration has attained new explosive force since the end of the twentieth century. This applies not only to the worldwide increase in the number of mobile women, but also to the global processes of economic restructuring, along with state and supra-state mobility regimes, that have resulted in feminized patterns and practices of migration (Anthias \& Lazaridis 2000; Sassen 2000). Since the early 1990s, gender researchers have been observing this trend in the European area as well, noting that - particularly in the wake of the Europeanization of migration policy - migratory movements are experiencing a feminization of which the illegalization of migrant women is a crucial feature (Kofman \& Sales 1998; see also Körber in this issue).

Sabine Hess starts from these debates in her study of the shift to governmentality in the European Union's migration regime. Using ethnographic and discourse-analytical methods, the author investigates the "anti-trafficking" dispositif - that is, the images and discourses of trafficking in women and forced prostitution that have made a major contribution to implementing, and now further refining, the political and legal constitution of the European border regime. As a participant observer over a substantial period, Hess took part in various EU round table disscussions in the field of migration policy, where participants in recent years have included not only politically nominated representatives and staff of the relevant regulatory bodies, but also members of NGOs, such as feminist activists. Hess draws on 
her many years of experience in the gender-sensitive research of border regimes to analyse the ambivalent effects of these new political practices. Underpinned by feminist discursive positions, they target the victimization of female migrants - with the result that ultimately even more restrictive controls of migration are legitimized. On the one hand, this case indicates how deeply the category of gender is inscribed in the procedures, technologies, articulations, and rationalities of the new European politics of migration; on the other, a degree of compatibility becomes evident between certain feminist positions and an increasingly rigid border-control policy, saying much about some approaches within feminist migration studies.

Hess shows that the Europeanization of migration policy can itself be understood as a transnationalization of politics. Her critical analysis of the antitrafficking dispositif points to a structural dilemma of "Fortress Europe": migrating women can only be represented through the figure of the victim, so that their transnational practices and spatial mobilities are negated. The victimization of women invokes as its Other the image of the settled woman, tied to the home, who must stay at her husband's side if she is to venture into the public space or across the national frontier.

To this extent, female migrants disrupt the symbolic order of gender and the family and become the object of technologized and networked knowledge practices, deemed to require documentation and control. Control over women and their bodies is also the theme of the contribution by Magdalena Radkowska-Walkowicz, who, in a different nationally coded field of knowledge, discusses how biotechnological change in reproductive medicine is casting doubt on traditional conceptions of family and evoking highly contested images of familiarity.

Radkowska-Walkowicz investigates the Polish debate on in-vitro fertilization. Through discourse analysis, she evaluates statements by representatives of the Catholic Church, who oppose the right to extracorporeal fertilization to great media and public effect, and commentaries by women affected, who use an Internet platform to share their experi- ences of assisted reproductive technologies. The author reaches the apparently paradoxical conclusion that while public allegiance to the Catholic Church is still relatively intact in Poland, large parts of the population are in favour of the use of reproductive technologies. She argues that the seeming contradiction in fact dissolves once the shared core of the argument is identified: both sides are propounding the normative ideal of the heterosexual nuclear family. Whereas for the women affected, this ideal is realized only with the birth of a child (even one that has been artificially conceived), the Church defends the ideal per se, in the shape of the marriage vow, to curb potential transformations of the family that would also permit other familial forms.

In their contributions, Hess and RadkowskaWalkowicz come to rather similar conclusions. Both authors, though working in different fields of research, ask how bodies and gender are constructed with the help of policies, regulations, and technologies. In the case both of transnational European migration policy and of national discourse around the use of reproductive medicine, the political actors are confronted with developments that seem to entail the "danger" of lost boundaries and of the unconfined developments, then, that seem to escape control. In one case it is the circulation of people, information, images, ideas, and products that crosscuts the state's attempts to reterritorialize, in the other biotechnology, enabling the separation of reproduction from heterosexual marriage, triggers a massive discursive campaign by the Catholic Church. At stake in both cases is the order of gender and the family, at the core of which is control over the female body, its spatial and corporeal circumscription.

\section{Conclusions}

The studies collected in this special issue approach the object of the family from various different directions. Through both historical and contemporary cases, they point out the restrictiveness of an ethnocentric concept of family, at the same time indicating the great adaptability of a social form whose downfall has been predicted so many times. The variety of approaches contributes to an under- 
standing of family that may be both less normative and less crisis-ridden, instead directing our attention to cultural and symbolic practices by which and within which families are "made", experienced daily, lived, and transformed. At the same time, as a pivotal representation of social order with great impact in everyday life, the family is also the place where the gender order is negotiated and renegotiated. In the course of transnationalizing processes, therefore, the family is "the primary unit of regulation and the vehicle of state power" (Ong 1999: 71); it is the target of state and supra-state policies, the object of legal regulations, and firmly embedded in public discourses whose gendered images play a key part in the construction of family. In the context of the increasing transnationalization not only of family relationships, but also of political forms, this field of tension will continue to gain in importance for future research.

\section{Note}

1 The article was translated by Kate Sturge.

\section{References}

Anderson, B. 1983: Imagined Communities: Reflections on the Origin and Spread of Nationalism. London: Verso.

Anderson, B. 2001: Multiple Transnationalism: Space, the State and Human Relations. Working Paper WPTC-01-15, www.transcomm.ox.ac.uk/working\%20papers/Anderson.pdf. Accessed June 14, 2012.

Anthias, F. \& G. Lazaridis (eds.) 2000: Gender and Migration in Southern Europe: Women on the Move. Oxford: Berg.

Baldassar, L., C.V. Baldock \& R. Wilding 2007: Families Caring across Borders: Migration, Ageing and Transnational Caregiving. London: Palgrave Macmillan.

Basch, L., N. Glick Schiller \& C. Szanton Blanc 1994: Nations Unbound: Transnational Projects, Postcolonial Predicaments, and Deterritorialized Nation-States. New York: Gordon and Breach.

Beck S., N. Çil, S. Hess \& M. Klotz (eds.) 2007: Verwandtschaft machen: Reproduktionstechnologien und Adoption in Deutschland und der Türkei. Berliner Blätter: Ethnographische und ethnologische Beiträge 42.

Beck, U. 2003: Das Meta-Machtspiel der Weltpolitik: Kritik des methodologischen Nationalismus. In: Armin Nassehi \& Markus Schroer (eds.), Der Begriff des Politischen. Soziale Welt: Sonderband 14. Baden-Baden: Nomos Verlagsgesellschaft, pp. 45-70.

Bendix, R. \& O. Löfgren (eds.) 2007: Double Homes, Double
Lives? Ethnologia Europaea: Journal of European Ethnology $37: 1-2$.

Bourdieu, P. 1977: Outline of a Theory of Practice. Trans. R. Nice. Cambridge: Cambridge University Press.

Bourdieu, P. 1990: The Logic of Practice. Trans. R. Nice. Stanford, CA: Stanford University Press.

Bryceson, D.F. \& U. Vuorela, 2002: Transnational Families in the Twenty-First Century. In: D. F. Bryceson \& U. Vuorela (eds.), The Transnational Family: New European Frontiers and Global Networks. Oxford \& New York: Berg, 3-30.

Carsten, J. (ed.) 2000: Cultures of Relatedness: New Approaches to the Study of Kinship. Cambridge: Cambridge University Press.

Chamberlain, M. \& S. Leydesdorff 2004: Transnational Families: Memories and Narratives. Global Networks 4:3, 227-241.

Faubion, J.D. (ed.) 2001: The Ethics of Kinship: Ethnographic Inquiries. Lanham, MD: Rowman \& Littlefield.

Harasser, C. 1996: Von Dienstboten und Landarbeitern: Eine Bibliographie der (fast) vergessenen Berufe. Innsbruck: Studien-Verlag.

Harzig, C. (ed.) 1997: Peasant Maids, City Women: From the European Countryside to Urban America. Ithaca, NY: Cornell University Press.

Henkes, B. 1998: Heimat in Holland: Deutsche Dienstmädchen 1920-1950. Straelen: Straelener Manuskripte.

Hondagneu-Sotelo, P. \& E. Avila 1997: "I'm here, but I'm there": The Meanings of Latina Transnational Motherhood. Gender and Society 11:5, 548-571.

Howell, S. 2001: Self-Conscious Kinship: Some Contested Values in Norwegian Transnational Adoption. In: S. Franklin \& S. McKinnon (eds.), Relative Values: Reconfiguring Kinship Studies. Durham, NC: Duke University Press, pp. 203-223.

Kofman, E. \& R. Sales 1998: Migrant Women and Exclusion in Europe. The European Journal of Women's Studies 5:3-4, 381-398.

König, R. 1974: Die Familie der Gegenwart. Munich: Beck.

Lima, F.H. 2001: Transnational Families: Institutions of Transnational Social Space. In: L. Pries (ed.), New Transnational Social Spaces: International Migration and Transnational Companies in the Early Twenty-First Century. London: Routledge, pp. 77-93.

Mahler, S. \& P.R. Pessar 2001: Gendered Geographies of Power: Analyzing Gender across Transnational Spaces. Identities: Global Studies in Culture and Power 7:4, 441-459.

Merkel, I. 2002: Außerhalb von Mittendrin: Individuum und Kultur in der zweiten Moderne. Zeitschrift für Volkskunde 98:II, 229-256.

Ong, A. 1999: Flexible Citizenship: The Cultural Logic of Transnationality. Durham, NC: Duke University Press.

Pries, L. (ed.) 2001: New Transnational Social Spaces: International Migration and Transnational Companies in the Early Twenty-First Century. London: Routledge. 
Sassen, S. 2000: Guests and Aliens. New York: The New Press. Sennett, R. 1998: The Corrosion of Character: The Personal Consequences of Work in the New Capitalism. New York: W.W. Norton.

Sørensen, N.N. \& L.E. Guarnizo 2007: Transnational Family Life across the Atlantic: The Experience of Colombian and Dominican Migrants in Europe. In: N.N. Sørensen (ed.), Living Across Worlds: Diaspora, Development and Transnational Engagement. Geneva: International Organisation for Migration (IOM), 151-176.

Vertovec, S. 2009: Transnationalism. London: Routledge.

Vuorela, U. 2002: Transnational Families: Imagined and Real Communities. In: D.F. Bryceson \& U. Vuorela (eds.), The Transnational Family: New European Frontiers and Global Networks. Oxford: Berg, pp. 63-82.
Karen Körber is a research fellow at the Jewish Museum Berlin. Her publications include books and articles on transnationalism, Jewish diaspora, migration and identity politics. A recent article is "Nähe auf Distanz: Transnationale Familien in der Gegenwart" (in Gertraud Marinelli-König \& Alexander Preisinger, eds., 2011, Zwischenräume: Migration und die Entgrenzung von Kulturen und Identitäten. Bielefeld: Transcript).

(k.koerber@jmberlin.de)

Ina Merkel is Professor of European Ethnology and Cultural Studies at Philipps-University in Marburg, Germany. Her research focuses on the history of film, culture and consumption in the G.D.R., gender and transnational mobility. Her latest paper is on historical-critical methods of film analysis and will be published in 2013 .

(merkeli@staff.uni-marburg.de) 


\title{
SO FAR AND YET SO NEAR Present-Day Transnational Families
}

\author{
Karen Körber
}

Through the expansion and development of communication technologies, transnational families are presently experiencing that they are close despite the great geographical distances between them. On the basis of a qualitative study with transnational families, I show that this virtual closeness at a distance brings out new practices of familiarity, on the one hand, but also produces conflicts and dilemmas, on the other. While the new technologies of closeness enable forms of everyday interactions over great distances, the compression of time and space does not take place in a vacuum. Instead, family members are positioned at interfaces of structures of difference and inequality, which decisively influence access to and use of the new technologies and which have far-reaching consequences for the shaping of transnational family configurations. ${ }^{1}$

Keywords: transnationalism, family, communication technologies, gender, migration regime

In his novel A Tale of Love and Darkness ([2002]2004), Israeli author Amos $\mathrm{Oz}$ described a recurring scene from his childhood in Jerusalem in the 1940s, vividly bringing back the reality of that time of a seemingly insurmountable distance, one which today seems like a stone's throw - that is, the distance between Tel Aviv and Jerusalem. In minute detail he described how his parents prepared for these telephone conversations that took place every few months with relatives in Tel Aviv. The call was first announced by letter, precisely fixing date and time, and then he and his parents would gather at the set time at the nearby pharmacy.

[T] he conversation went something like this: ... "Yes, Arieh, hallo, it's Tsvi here, how are you?"

"Everything is fine here. We're speaking from the

\author{
pharmacy." \\ "So are we. What's new?" \\ "Nothing new here. How about at your end, Tsvi? \\ Tell us how it's going." \\ "Everything is OK. Nothing special to report. \\ We're all well." \\ "No news is good news. There's no news here ei- \\ ther. We're all fine. How about you?" \\ "We're fine too." ... \\ And then the same thing all over again. How are \\ you? What's new? ... \\ And that was the whole conversation. \\ (Oz [2002]2004: 11)
}

Descriptions like this, in which the elaborate preparations for the telephone calls assumed the character of a ritual that was at least as significant as the 
conversation itself, were also common in interviews of our research project with families that became transnational through the labour migration of part of the family in the 1960s and which report of how arduous and protracted efforts had been in the past to maintain contact over spatial distances. ${ }^{2}$ With the mass expansion and rapid development of telecommunication technologies since the 1990s a fundamental shift can be observed, especially with respect to the ways people communicate over a distance. Whereas past generations commonly experienced that it could take months for news to reach them from far away, now family networks spread out over great distances can maintain regular and immediate contact with each other with the help of new technologies. Inexpensive telephone charges, mobile telephones, and the Internet have facilitated the rapid transfer of money, goods, and information, giving the impression that spatial barriers are steadily disappearing. Arjun Appadurai observed that today's world is characterized essentially by "objects in motion ... ideas and ideologies, people and goods, images and messages, technologies and techniques" (Appadurai 2001: 5). This seems to apply to the reality of transnational families in a special way, including the everyday experience of "time-space compression" (Harvey 1990: 240-242) as a result of the use of new technologies.

In the following I will examine the consequences of this shift and ask how families create familiarity across great distances. Within this context it is important to discuss the limits of the concept of family, among the crucial elements of which is the experience of shared time at a common location in other words, spatial proximity and direct community. My empirical basis is a qualitative study of families whose transnational character developed in the 1950s and 1960s, and after 1990, within the scope of labour migration to Germany and Austria. Using selected cases from this sample I would like to show that the creation of familiarity in the families we studied is characterized by a tension involving a number of overlapping processes. For present-day transnational families the change in time-space organizational patterns is tied to the specific experi- ence of feeling close also over great distances. This virtual closeness despite physical distance brings forth new practices that allow spatially fragmented families to create forms of everyday togetherness, thereby serving to increase the significance of familiarity as a value, longing, and myth, and allowing it in fact to be experienced and lived at times in various casual structures. Although this development appears at first glance to facilitate the project of living as a transnational family, upon closer scrutiny it becomes apparent that the compression of space and time can also bring out conflicts and dilemmas for family members. For one thing, members of transnational families are confronted with various problems deriving from the situation that increased options for accessibility also lead to increased expectations of being accessible. Furthermore, transnational communication does not take place in a vacuum. Family members are instead positioned at interfaces of structures based on difference and inequality that decisively influence access to and use of the new technologies. These complex, asymmetrical relations with respect to gender, ethnicity, nationality, and age develop their own specific influence within the context of migration regimes, whose mechanisms of incorporation and restrictive policies have consequences for the shaping of transnational family configurations. With respect to the families in our sample, the "mobility order" (Rogers 2004: 174) of the present European migration regime gains special significance in this context. The increasingly restrictive migration policies of the European Union, in particular Germany and Austria, are feminizing migratory movements, which produces a paradoxical experience as it were for female family members: apparently unlimited in their geographic mobility, they confront the limitations of the national migration regime, which in most cases allow them only unofficial and illegalized paths to the West (see article by Hess).

After a brief survey of the present state of research on transnational families, two cases from the sample shall serve to illustrate some of the problems and structural dilemmas that are connected to the experience of virtual proximity at a distance. Both 
of these examples are from a corpus of twenty-five families, with whose members - that is, parents and their (usually) grown children - biographical narrative interviews (Apitzsch 2003; Schütze 1983) were conducted. Corresponding to the labour recruitment agreements of the 1960s, families from Italy, Greece, Turkey, and the former Yugoslavia were selected. Also, families largely from Eastern Europe were interviewed, whose transnational life circumstances did not begin until the Iron Curtain fell after 1990. This included families from Ukraine, Belarus, Russia, Lithuania, and Slovenia. In addition we selected a small number of families that immigrated within the scope of labour migration and in doing so had to overcome incomparably great spatial distances. This group includes migrants from South Korea who were recruited in the 1960s as nurses, and women from Peru and Colombia, who have been working for a number of years in Germany and Austria as domestic workers. There are thus two groups of transnational families in the sample, which differ with respect to the duration of the migration process and the respective legal conditions for migration, as well as regarding the means of communication and transportation available for their endeavour to establish their family beyond national borders. ${ }^{3}$

\section{Transnational Families: State of Research}

Since the 1990s authors have observed that in the course of advancing globalization, more and more family forms are developing whose members spend their everyday lives separated from one another by great distances and national borders, but they nevertheless remain cohesive due to viable emotional and financial ties. Transnational families are by no means a new phenomenon, as historical studies show. Also in the past, immigrants from the Old World wrote letters to relatives reporting about their new home and sent money to cover the ocean passage (see also Thomas and Znaniecki [1918]1984; Yans-McLaughlin 1990). Studies in the countries of the Caribbean and Central and Latin America have for quite a while been drawing attention to a development in which migration becomes a central pattern for how families lead their lives, assuming the status of a social norm (Nyberg Sørensen \& Fog Olwig 2002; Fog Olwig 2003).

At the same time expressions such as "transnational parenting" (Parrenas 2001: 62) and "longdistance mothering" (Gamburd 2000) provide evidence of current migration processes being characterized by qualitative and structural changes that become visible also (and precisely) in transnational families. This includes, for one thing, the feminization of migration since the 1980s, which challenges the symbolic family order and poses the question as to images and expectations of motherhood anew. While studies on migratory movements of women in the late nineteenth century already referred to gender-specific migration practices, the sphere of globalized domestic employment is today the most important labour market for women worldwide and with respect to hiring and recruitment practices it is considered to be better organized than ever before (Momsen 1999: 5; Lutz 2011). Furthermore, the new technologies allow members of transnational families "to be actively involved in everyday life there in fundamentally different ways than in the past" (Levitt 2001: 22). These developments have become the subject of studies that direct the attention to "distanced" models of familiarity, taking the changed time-space relationship into account.

In one of the first studies on transnational motherhood, Pierette Hondagneu-Sotelo and Ernestine Avila used the example of Latin American migrants in the United States to express - in their aptly titled essay "I'm here, but I'm there" - not only the longing of mothers for direct community but also the specific experience of creating new forms of closeness and intimacy as conveyed through regular telephone calls (Hondagneu-Sotelo \& Avila 1997). American sociologist Rhacel Parrenas (2005), in her study of transnational families from the Philippines, treats the perspective of the children left behind. She analysed the constitution of gender in such transnational interactions, showing that the absent mothers not only assume the role of the male breadwinner in order to secure the livelihood of their families, but through emails and telephone calls they attempt to compensate for the gender-specific expectations on 
them for care. Parrenas observed that the practices of the women have served to redefine a concept of motherhood such that forms of material support are understood as expressions of maternal caregiving. Under the heading of transnational care, Loretta Baldassar et al. pursue the question of how the relationship between aging parents and their grown children is shaped against the background of great spatial distances (Baldassar, Baldock \& Wilding 2007). In their study, the authors not only worked out "distant" practices of transnational care in family life, but also referred to a family network structure that is based on the principle of a "specific reciprocity" (Faist 2000: 106ff.).

In the present article I refer to these studies, therefore rejecting an understanding of transnationality that concentrates primarily on the mobile actors. I aim instead to show how in the course of exchange processes within the family both mobile and immobile family members actively participate in maintaining transnational social and symbolic ties (Brah 1996; Brennan 2004; Levitt \& Glick Schiller 2004). I employ those approaches which do not view families as homogeneous units and instead look at how family relations are characterized by structural inequalities (Dreby 2006; Schmalzbauer 2004). Such a perspective views the family as a community of individuals, each with his or her own interests and experience. This also means that members select when, with whom, and in what way they maintain family ties. Attention is thus directed at those practices, strategies and negotiation processes through which family members "create familial space and network ties in terrain where affinal connections are relatively sparse" (Bryceson \& Vuorela 2002: 11).

\section{Whoever Emigrated "Was Simply Gone”}

Back then there was one shared telephone for the whole town and that's where my mother would call. My mother always collected 5-mark coins. When she called us she always went to a coin machine [i.e., a telephone booth], put in the 5-mark coins, and then called so someone would tell us. Then we'd come and she would call again. Mostly we talked about what was absolutely necessary. ${ }^{4}$
Such reports were common among our interviews with members of transnational families that were involved in labour migration in the 1960s. All conversation partners reported that private households in the respective countries of origin did not have telephone connections in the 1980s and that also those family members who had emigrated only rarely had their own telephones. Long distance calls were an expensive, public act. The main medium for communication was the letter, or a package with cassettes. This in turn was connected with waiting periods, which underscored the great geographical distance between members of the families. "That always took a long time, yes. It could take three to four weeks before you got an answer." Whoever emigrated "was simply gone, far away", as one of our interview partners summarized the family experience of these years. This also involved the gradual acknowledgement that what had begun as an exceptional, short-term situation, in many families changed to something "temporary that lasts" (Sayad 2004: 74), which stabilized, demanding new plans for organizing family life over great distances.

The family of Sophia Wassiliou, in her mid-forties and proprietor of a hairdressing salon in Frankfurt am Main, is such a case. Sophia's family came from a village near Thessaloniki, Greece. Her mother described life as characterized by the harsh conditions of agrarian life, of hardship and small yields, too little to feed a family. The labour migration seemed to be the final recourse, an act of necessity. The elder brothers of Sophia's father were the first to leave for Germany, then a brother of her mother. Recommended by his brother-in-law, Sophia's father was offered a job in a Volkswagen plant in northern Hesse as an unskilled labourer. He emigrated before the birth of his daughter, and his wife followed three years later, also to work in Germany. The three children remained in the village with their grandmother. When the parents realized that their economically successful return would take longer than they had expected, they brought their children to Germany as well. Because their workdays were long and hard, the children were often left to their own resources. Soon the two older brothers were sent back to relatives in 
Greece so they could attend secondary school there. The family only got together during summer holidays in the village where they came from, in order to work on the project of building their own house.

So there were certain years and then there was always a separation again. Good, so that's how things went all those years. And there were always tears, yes, always farewells and tears and farewells and tears. ${ }^{5}$

Similar to how Ayse Caglar (1997) analysed the situation of Turkish labour migrants, the myth of returning determined the everyday activities and family decisions in the life of the Wassiliou family. In social practice, the mentioning of the return took on the force of a key symbol: "It was always clear that somehow, sometime we would go to Greece. That was our family story."

Nevertheless, all three children started settling in as young adults in Germany. When family life seemed finally to shift to Germany for good after the sudden death of the father, the mother decided to return to the village she came from. This decision raised the painful question once again as to where and how they could set up a life they shared, a process which revealed the myth of return to be an illusion. In the interview, the daughter Sophia described her decision not to return, in which she referred to how different the circumstances of her life were from those of her parents:

But it has become totally different for us. As soon as I realized that, I said: “OK, I can't leave here [Frankfurt] totally; I don't want to; what options do I have? Fly there often." And then I told my mother, "You will have to understand that somehow, that your children will come and go..." Yes, and now it has worked out so that basically we try to see each other as frequently as possible and, of course, through all these options - telephone, Internet - everything has become much easier. ${ }^{6}$

Sophia Wassiliou was referring here to a difference in the experience between the generations, which comes out especially in the different narratives that introduce the respective migration stories. Whereas the story of her mother carries qualities of an inevitable "either-or", the daughter experiences her family life at a distance more as a "both-and" (Kearney 1995: 558), in which everyday practice - virtual, communicative, and practical - makes it possible to overcome the distance and limitations without any effort. This description not only gives the impression that Sophia, in contrast to her mother, has a sense of belonging to more than one place, it also describes the conditions under which she decided to stay in Germany. Fate gives way to an active choice.

The narratives of the Wassiliou family reveal not only a change in perspective away from the shared notion of a remigration and towards awareness that the family already has numerous transnational references at its disposal. Their statements also reflect a specific experience of labour migrants of the 1960s who had come to West Germany as EU employees in the course of bilateral recruitment treaties. Sophia's parents were awarded legally regulated residential status, the right to choose their place of residence (right of mobility) and thus legally privileged status as compared with migrants from non-European Union countries. Since the German economy had an interest in trained workers, the planned rotation was suspended and family reunions in Germany were permitted. At the same time, Sophia's parents came from an economically depressed region in Greece and had had limited schooling - a fate they share with many labour migrants from EU countries in south-eastern Europe. Their economic status thus corresponded to that of the classical reserve army of labour in the country of origin. Although their income was much higher than what they would earn in Greece, it required that they accepted as a matter of course hard workdays with great sacrifice. This situation - similar to other families in the sample - led to children going back and forth between country of origin and country of destination. At first they remained in the country of origin with the grandmother; later the two sons were sent to Greek relatives so they could attend secondary school there. The parents' decision to put the children under the 
care of a network of relatives in the area of origin was not unusual at the time. Instead, it fits into an understanding of family that is based less on the nuclear family and much more on the extended family, in which care for the children is transferred also to other (mostly female) relatives (see Erel 2002). In the course of familiar chain migration, as in the case of the Wassiliou family, these care arrangements take on additional significance, since the great spatial and temporal distance requires a reliably functioning transnational family network. With this step Sophia's parents emphasized their intention to return, on the one hand, and they reacted to the social restrictions and discrimination they were confronted with in Germany, on the other. This included the experience that their adolescent children faced difficulties or were even denied higher schooling, which was why the parents decided that they should acquire this qualification in their country of origin (see Apitzsch \& Siouti 2008: 98f.). The transnational living space that was established could, in its beginnings, also be seen as a reaction of the labour migrants to the exclusionary tendencies of the host society.

\section{Compression of Time and Space}

The changes that Sophia's family went through indicate, first of all, how the first generation's initial perspective on migration as one-time, temporary, and return-oriented often became a long-term, flexible, and intergenerational way of life for the family, located in various places both socially and culturally. In addition, Sophia's experiences also reflect the dynamic development of communications media and means of transportation, the "material infrastructure" of transnationalization, which according to Ludger Pries is what enables "the migrants to remain mentally present in their families and places of origin" in the first place (Pries 1998: 77).

Without exception, everyone interviewed in fact described that these developments greatly facilitated their family life at a distance, although there were differences among the interviewees in terms of both their respective options for access and the ensuing costs. In particular "cheap calls" (Vertovec 2004:
219), that is, the possibility to make inexpensive telephone calls worldwide, has changed the families' perception and underscored the impression of what Frances Cairncross characterized as the "death of distance" (1997: 27). Reports on the daily call "just because", in which someone could sometimes even learn of something "before everyone there heard about it", underlines the feeling that "I know everything that goes on there even though I am here". The progressing pregnancy of a daughter can be observed via webcam, and cousins can "chat" between Sydney, Frankfurt and Chicago on the Internet. But not only the ways and means of communication have changed. The possibility to exchange information frequently, spontaneously and informally generates a "virtual intimacy" (Wilding 2006) among the participants, which helps to make the physical absence lose significance, at least for the time being. Communication technologies researcher Christian Licoppe came to similar conclusions in his studies, in which he described: "Communication technologies, instead of being used (however unsuccessfully) to compensate for the absence of our close ones, are exploited to provide a continuous pattern of mediated interactions that combine into connected relationships' in which the boundaries between absence and presence eventually get blurred" (Licoppe 2004: 136). Most of the mediated interactions thus lead not only to a compression of time and space, but give the impression of shared time and space despite the physical distance. This experience of simultaneity over great geographical distances is an essential factor, enabling transnational families, as "imagined communities" (Anderson 1983; Vuorela 2002: 63), to create and maintain shared notions and narratives of cohesion and belonging.

Taking a closer look at how the increase in mediated interactions developed within the families we studied, it is apparent that the communication technologies available were not used by all participants to the same extent. While contact to the older generation is generally maintained by telephone, the middle and younger generations use especially the Internet - that is, email - in addition to telephone and mobile phone, in their communications. 
We hear from each other regularly, also the cousins, etc. ... So now I actually have much more contact with them than my parents. And through Facebook I have ... the contact is maintained, like, I don't know, by exchanging pictures or whatever, and talking a little and sending messages; that usually is kept up through Facebook. ${ }^{7}$

What at first glance signals only a change in medium, turns out when looking closer to be a change that also has consequences for the ways family members refer to one another. First, the increased use of the Internet means that information can be passed on within the shortest possible time to a large number of people. Thus the circle of people who can potentially be informed of "family matters" and who feel connected is expanded. In particular among members of the younger generation the Internet has created new forms and forums for coming together through the various social networks such as Facebook. Here, independent communication between peers is possible over great geographic distances, which is significant in order to maintain a sense of familiarity. Also, the medium of Internet has increased the number of male participants in family communication, since they are generally more willing to send an email than to pick up the telephone. Both developments contribute to the fact that two different patterns can increasingly be observed within families. Both for letters that had been written in the past and for the telephone, which increasingly replaced letter-writing, it was and is primarily women who maintain this communication:

The women talk to each other on the phone much more often and that is really like: My mama picks up the phone and then her sister will be called, and then the other sister, and the aunt, and everything is discussed with one another. ${ }^{8}$

Such descriptions, which give female relatives a key function in terms of gathering and passing on information, refer to a network with one person at the centre who is responsible for exchanging and directing transnational communication. Through media such as the Internet and email, parallel networks are emerging, "in which communications proceed simultaneously in more or less all directions" (Urry 2003: 160). The structures of these media appear to be looser and less binding, but at the same time they involve a larger circle of participants who in different ways can participate in or help shape family events.

From a historical perspective we are thus dealing with a unique extent of closeness created through communication, which results in a new problem for the members of transnational families in our sample. The virtual closeness over a distance corresponds to the insight that one's own actions remain indirect, conveyed via media, and - for example in the case of a family crisis - are no substitute for co-presence. This experience produces new dilemmas for members of transnational families, which go hand in hand with the availability of new technologies. When in many cases distance no longer represents an insurmountable barrier, then one's own absence no longer assumes the character of fate, but instead increasingly becomes an act of decision-making. If, when and under what conditions family members get together is thus the subject of negotiations of what comprises family obligations and responsibilities (Urry 2003: 169). In other words, the increased opportunities to be accessible also lead to increased expectations of accessibility.

Sophia Wassiliou also shared this experience. Similar to other people we interviewed, she stressed the close contact with her birth family. Through inexpensive telephone tariffs and the Internet she can communicate daily with her mother and relatives. The expansion of means of transportation - in particular inexpensive air travel - has multiplied the options for travelling very quickly to her hometown in Greece. At the same time her descriptions also present an unspoken problem: Sophia knows that she will not be there if something happens to her mother. The daily calls and the detailed knowledge of the various flight connections stand for her promise to be there as fast as possible in case of a crisis. When she was told that her grandmother in Greece lay on her deathbed, she had to admit that in reality such a promise could always fail. 
And I tried to still get a ticket and it was just not possible. And I had already prepared myself for it ... to say goodbye to her and it was just impossible, no matter what ticket I had taken, even though we are in Frankfurt and I would've had to fly via Athens and then, well, I never would have made it. ... And that made me totally crazy, because I thought, I just can't believe it! ${ }^{9}$

Although Sophia Wassiliou looked into various travel routes, she did not make it there in time. Her frustration and anger is an expression of a series of dilemmas that emerge through access to "time- and space-compressing technologies". One of them is that the technological changes and facilitated access have served to increase mutual expectations and commitments within transnational families. Furthermore, this change can also lead to a reassessment of the migration process itself. If long-term processes of immigration and emigration give way to virtual and spatial interrelations that can be set up individually and flexibly, then the standards for assessing life at a distance also gradually change. The guilty conscience that one senses from Sophia's account traces back to a self-attribution in which she assessed her own absence as the consequence of an individual decision that she could have also made differently. But whereas Sophia and her relatives enjoy freedom of movement within the legal space of Europe, flexible and mobile interrelations in many cases are also an expression of restrictive European immigration policies, whose border regimes separate the demand for immigrant labour from the workers' social reproduction, thereby largely contributing to the transnationalization of families.

\section{Virtual Closeness at a Distance}

One example of this is the story of Ingrida Einars. Ingrida, 38 years old, is from Kaunas, Lithuania. She has been living and working in Frankfurt am Main since 1998, although her eighteen-year-old daughter Danuta stayed in Kaunas with her grandparents. Like the Wassiliou family, Ingrida had planned to spend one or at most two years in Germany. However, the legal conditions of her migration are fundamentally different from the basic conditions of the recruitment measures of the 1960s. Whereas the Wassiliou parents received legally regulated residential status in the course of so-called guest worker migration, which provided for their children to later join them, Ingrida is subject to the restrictive requirements that the countries of the European Union, and especially Germany and Austria, implemented in the 1990s through the Schengen agreement. Not only does this treaty provide for a stepwise system of selective immigration controls both internally and externally, it limits in principle the right of people from Eastern Europe to move and reside freely and abolished the right to settle - with few exceptions - almost entirely (Bade 2003: 288-290). British sociologists Eleonore Kofman and Rosemarie Sales have determined that the few remaining legal forms of labour migration address primarily the migration of men, whereas migrating women are increasingly forced to resort to unofficial means (Kofman \& Sales 1998). The disproportionate illegalization of the migration of women has led to specifically female migration patterns and job opportunities developing especially within the so-called low-skilled and informalized service sector. Aside from the sex industry, it is predominately work in private households - that is, the unregulated and informalized area of domestic help - that is available to most female migrants as a chance for employment (see Anthias \& Lazaridis 2000). This was also the case for Ingrida Einars. Until Lithuania joined the EU in 2004 she was eligible for a three-month tourist visa, and after 2004 a bilateral treaty between Germany and Lithuania abolished the visa requirement for tourists. Ingrida Einars was able to enter Germany but she had no work permit. She worked illegally and unregistered as a seamstress in a sweatshop together with other Eastern European women. Later she took on various cleaning jobs, and not until 2009 did she register her own cleaning services as a business. Her irregular status has led to her not being able to have her daughter join her, especially since the restrictive German legislation provides for neither the right for her child to attend school nor sufficient rights to adequate healthcare. Similar to the account of Mirjana 
Morokvasic (1999), Ingrida left her home in order to be able to maintain it. Migration made possible for her what she could not accomplish at home: to earn a livelihood for herself and her daughter and to renovate the house in Kaunas where Danuta and her grandparents live. In the interview Ingrida described her own lifestyle as torn: "I have one foot here and one foot there." This statement expresses not only her longing for a life together with her daughter, but also the fact that she has been living with a man for several years in Frankfurt - a situation that her birth family does not approve of and which continues to stabilize the circumstance of separation.

At the same time, Ingrida's statement is evidence - similar to those in the studies on transnational motherhood (Parrenas 2005) - also of her attempt to be there for her daughter even over a distance and to provide both emotional and material care. Unlike the families involved in labour migration in the 1960s, Ingrida Einars can compensate for the geographical separation from her family through daily use of new communications media. Over the years she has built up a complex network of conversation partners who help her participate from a distance in the family life "at home". Via telephone, Internet and Skype she communicates regularly with her daughter, her parents and her sister, whose family lives next door. If acute financial problems arise, she can transfer money almost immediately. If her parents complain about their granddaughter, she tries to assuage the situation from a distance, occasionally asking her sister to help out. Ingrida keeps abreast of Danuta's school achievements, not only through her daughter directly, but also through the school's Internet portal, where absent parents like Ingrida can see their children's grades from a distance. In addition, she and Danuta's teacher communicate by email about Danuta's progress in school. What at first sounds like a success story of modern communication technologies must be qualified when looking closer at how this communication is organized in practice. Ingrida's parents have both been suffering for years from a hearing disability that makes talking on the phone very difficult. Both parents can write but have had very little practice so that written con- tact is in fact not really possible. In the initial period of back-and-forth migration, Ingrida was therefore only able to have contact with her young daughter and her sister, who occasionally served as mediators between her and her parents. Not until the family in Kaunas gained access to a computer, webcam, and an Internet connection was it possible for Ingrida to communicate with her parents via Skype from a "call shop" in Frankfurt. Now she is able to use her partner's computer. Since Ingrida's parents are not very proficient at using the computer, they need to rely on their granddaughter to prepare the necessary computer set-up for them to be able to communicate with Ingrida using the keyboard, individual words, and sign language. This laboured communication is even more difficult due to interruptions in the connection and deficient picture quality. Despite these problems, Skype and webcams have in fact made it possible for Ingrida and her parents to have direct contact with each other.

Whereas in this case the technological innovations are a necessary prerequisite for the communication, they have also given rise to an opposite effect when Ingrida Einars tries to contact her daughter. When Danuta entered puberty Ingrida was confronted via Skype and webcam with the (not unusual) changes her daughter was going through: nail polish, dyed hair, and a lip piercing made Ingrida fear that her daughter might go astray, causing her to seriously consider returning to Kaunas, a thought she later abandoned. Mother and daughter decided instead to change the medium of their communication. Their daily exchange now takes place via email, since both of them discovered that the webcam and computer telephone conversations created a closeness that they had difficulty dealing with emotionally from a distance.

We write. Whenever we talk we end up arguing. Always, almost every time we talk, I give some kind of sermon and she raises her voice a bit when she responds and that's it. Then it just takes off from there. But when we write I don't hear her tone, since it doesn't come through the writing. And that's better. ${ }^{10}$ 
Conflict-laden conversations between parents and their pubescent children are an everyday part of family life, whether they are interacting under the same roof or over a great distance. While the conflict in a face-to-face situation can be carried out by, for example, slamming doors and avoiding each other's glance at meals until the waves of escalation begin to ebb, in this case mother and daughter have taken a course that is much more rational. Since the goal of communication from a distance is to maintain communication per se, it requires controlling anger and curbing emotions in order to avoid potential conflict; otherwise the escalation can lead only to ending the conversation and, with that, all contact.

Ingrida Einars's story is exemplary for a series of experiences shared also by other interviewees, including the knowledge that family interactions can indeed be carried out via the Internet and telephone, but the indirectness and mediatization of the contact also changes the quality of the relationship. The virtual closeness can generate emotions that as perceived by family members cannot be adequately dealt with through the new communication technologies. The dilemma of the illusion of closeness produces not only disappointed expectations among the conversation partners, but can also lead to reflections on how to deal with the corresponding media. This can involve weighing considerations of the possible emotional repercussions of a short-term "virtual intimacy" against the long-term goal of successfully maintaining contact. The decision of family members as to which of the available media might seem best suited for communicating with each other can also be understood as an attempt to appropriately fathom the relationship between closeness and spatial distance.

This leads to another experience shared by members of transnational families. Using media such as mobile telephones and the Internet they continually become involved in difficult family situations that nevertheless take place elsewhere. As Ingrida Einars's example shows, she is directly available but can only indirectly take action, a situation that she experiences with emotional ambivalence. The new technologies make it possible for her to do whatever she - in agreement with her family - decides is necessary. Almost immediately she can put through a bank transfer or share ideas and information, but she is not there in person. This leads to a feeling of tension that also comes from a sense of asynchrony, namely, of being close to the absent person virtually, whereas one's actions are bound together, as Norbert Elias described it, in extended "chains of action", which have been "lengthened" in the course of interdependent transnational contexts (Elias 2000: 370). As Ingrida's example shows, her scope of action had been considerably expanded, yet at the same time she cannot anticipate the outcome of her actions. This awareness increasingly pressures individuals to "take account of the effects of his or her own or other people's actions on a whole series of links in the social chain" (ibid.: 370 ), but without losing the insight that in the end they do not regain control of their intended actions.

The dilemma that has emerged for migrant women in our sample is especially apparent regarding matters of distributing money in transnational families. Similar to Ingrida Einars's case, also in other families a large share of the earnings of the migrant women is used to support their family network in their region of origin. An attempt is made to control the distribution of the funds from a distance by transferring money to one particular person in the place of origin who then makes decisions regarding the further distribution there. As a rule this contact is a female relative, such as their own daughter or a sister in the family (see Gamburd 2000; Parrenas 2005). The migrants can, however, never really check whether or not their money transfers are used as they intended. Also, the chain of family obligations and problems does not end, as can also be seen in the example of Ingrida Einars. From the costs to renovate and maintain the house to financing the daughter's education and the parents' visits to the doctor, new demands and emergencies continue to arise, which prolong the migrant's stay in Germany in order to earn the necessary money. Conversely, Ingrida Einars is dependant on the support of the family network, especially with respect to caring for her daughter. This "moral economy of family loyal- 
ties" (Lutz 2008: 161) leads to close, often also burdensome, emotional and mental ties with the region of origin, which at the same time makes it all the more difficult to take advantage of opportunities to establish one's own life in the place of destination.

These accounts clearly show that the use of new communication technologies does not take place in a vacuum, but that the compression of space and time is embedded in a "power geometry" (Massey 1993) characterized by structures of social inequality that exert a determining influence on the positioning of the individual family members. Access to these technologies presupposes that the parties involved are either financially in a position to acquire the necessary equipment or that a local infrastructure exists, such as "call shops", which offer inexpensive opportunities to have contact. Family members are thus confronted both with economic constraints that can limit transnational contact (Mahler 1998) and with the unequal distribution of resources worldwide or the existence or lack of varying technological infrastructures in urban areas such as Frankfurt am Main and Kaunas.

In addition to the fact that the respective economic and technological accessibility of transnational communications media has far-reaching consequences for the success of this communication, the example of the Einars family indicates additional factors of social inequality that greatly determine the actual options and abilities of the individual participants in the communications. The new technologies thus enable contact between Ingrida and her family in principle, but this communication also displays an asymmetry that determines its form. Whereas Ingrida's daughter was too young during the first few years of Ingrida's migration to independently engage in contact with her absent mother, the grandparents had to painfully admit that, due to their physical disabilities and insufficient technological savvy, they did not always have the necessary means or unobstructed access at their disposal to be able to enjoy unrestricted use of these new technologies (see also Baldassar 2007).

\section{Conclusions}

The two cases of Sophia Wassiliou and Ingrida Einars do not only reflect a short narrative on the compression of time and space, they also illustrate the different realities of labour migration in the 1960s and 1990s. Both families have developed forms of familiarity at a distance which, for one thing, make the great technological leaps apparent and, for another, show how the different legal conditions for migration offer the families a framework to refer to in shaping their own transnational experiment. The case of the Wassiliou family is exemplary for how the specific positioning of the EU labour migrants in the 1960s influenced the family structure. Unlike the case of Ingrida Einers, the parents of Sophia Wassiliou were recruited and then given permanent residential status that provided for the right to move and reside freely and the right to reunite the family by allowing other family members to join them. This legally privileged position was combined with an economic status in which the migrants were better off than in their country of origin, yet they were confronted with tendencies in the host country to close itself off to immigrants, which caused the family to take advantage of transnational family networks to arrange for the extended family to participate in caregiving in the country of origin.

Sophia Wassiliou's family has a citizenship that allows family members to develop multi-local reference points within the European sphere. Ingrida Einars's situation, however, illustrates the development of European migration policies that reflect a dependence on migrant labour, on the one hand, but which are increasingly restrictive towards them, on the other. This development goes hand in hand with a political and legal practice leading to a feminization and illegalization of migratory movements, as also experienced by Ingrida Einars. Her irregular employment as a domestic worker long denied her the opportunity to bring her daughter to join her in Germany. In contrast to the Wassiliou family, however, she had greater spatial mobility from the very beginning of her migration and was able to maintain contact to her family in Lithuania by virtual means. Present-day communication technologies allowed 
her to develop everyday practices and routines of transnational motherhood while assuring her financial support of the family. At the same time, however, she has been denied the opportunity to develop any lasting prospects for a future in Germany, since both the legal regulations for migration in the country of destination and the continuing financial demands of her family in the country of origin hamper such a project.

These two examples show how a concept of familiarity that remains tied to face-to-face relationships at close proximity ignores the ways in which new technologies create closeness and how the related practices make it possible to create and maintain a family lifestyle spanning great geographical distances. At the same time this clearly shows that participation in this process is essentially characterized by the individuals' (unequal) social positioning, which largely determines the respective opportunities to use these technologies. This applies not only to family members who physically engage in the cross-border mobility, but also to those who remain at the places of origin, because they too actively help shape the transnational relations. Against this background, members of transnational families experience the new technologies as a relief, on the one hand, since they enable everyday interactions in which familiarity can be experienced. On the other hand, along with the increased options for crossing virtual and spatial boundaries quickly and flexibly, the evaluating standards with respect to the decision for a life-at-a-distance have changed. While migration used to be connected with the burden of necessity, today's mobile lifestyles seem more and more to be an act of choice, taking wishes to shape one's own life into account. What is subjectively perceived as a process of individualization, however, is the outcome of a European immigration regime that produces flexible and mobile labour, but which places the responsibility for the consequences of these constraints on the migrants themselves.

\section{Notes}

1 The article was translated by Allison Brown.

2 The Transnational Familiarity research project (Prof.
Ina Merkel, Dr. Karen Körber, Mag. Polina Kirjanenko) was conducted from 2008 to 2011 at the Institute for European Ethnology/Cultural Studies at the Philipps University, Marburg. It received funding from the German Research Foundation (DFG).

3 The interviews were conducted in Frankfurt am Main and in the Rhine-Main region, as well as in Vienna. These cities and regions have been affected by processes of migration and mobility for decades: The share of the population with a migration background in Vienna is roughly 32 percent of the overall population; the figure is 39.5 percent for Frankfurt am Main, and 38 percent in the Rhine-Main region. Through contacts to immigrant organizations, cultural and religious associations, and schools, which served as networks and hubs, we were able to gain access to the field, finding the families for our sample through the snowball effect. The interviews were conducted in either German or Russian and in isolated cases interpreters were used. Because limited research funding was available, we first interviewed members of the families living in the greater Frankfurt area or in Vienna and then those family members who shuttled regularly between Germany or Austria and their respective country of origin, or those who were visiting in Frankfurt or Vienna. Finally, a group interview with the family was carried out. We also gathered data using the methodology of participant observation to determine how family members organized their transnational communication. In addition, we participated in both private family celebrations and religious services and festivals as well as activities organized by immigrant organizations, in which the families were present in various different configurations. The interviews were transcribed and then evaluated on the basis of hermeneutic processes (Fischer-Rosenthal \& Rosenthal 1997). Thus patterns of action and interpretation were reconstructed in order to reveal those - often invisible - "structures of intricately networked state, legal, and cultural transitions, which provided a biographical orientation for the individuals and represented a shared experience for them" (Apitzsch 2003: 69).

4 Interview with Wassilis K. on 11 May 2009 in Frankfurt am Main, transcript, p. 5.

5 Interview with Sophia Wassiliou on 10 February 2010 in Frankfurt am Main, transcript, p. 3.

6 Ibid., transcript, p. 5.

7 Interview with Raina S. on 12 October 2010 in Wiesbaden, transcript, p. 9.

8 Ibid., transcript, p. 8.

9 Interview with Sophia Wassiliou on 10 February 2010 in Frankfurt am Main, transcript, p. 17.

10 Interview with Ingrida Einars on 16 December 2010 in Frankfurt am Main, transcript, p. 15. 


\section{References}

Anderson, B. 1983: Imagined Communities: Reflections on the Origin and Spread of Nationalism. London: Verso.

Anthias, F. \& G. Lazaridis (eds.) 2000: Gender and Migration in Southern Europe: Women on the Move. Oxford \& New York: Berg.

Apitzsch, U. 2003: Migrationsbiographien als Orte transnationaler Räume. In: U. Apitzsch \& M.M. Jansen (eds.), Migration, Biographie und Geschlechterverhältnisse. Münster: Westfälisches Dampfboot, pp. 65-80.

Apitzsch U. \& I. Siouti 2008: Transnationale Biographien. In: G. Homfeldt, W. Schröer \& C. Schweppe (eds.), Soziale Arbeit und Transnationalität: Herausforderungen eines spannungsreichen Bezugs. Weinheim: Juventa, pp. 97-111.

Appadurai, A.J. 2001: Grassroots Globalization and the Research Imagination. In: A.J. Appadurai (ed.), Globalization. Durham, NC: Duke University Press, pp. 1-21.

Bade, K. 2003: Migration in European History. Trans. A. Brown. Oxford: Blackwell.

Baldassar, L. 2007: Transnational Families and Aged Care: The Mobility of Care and the Migrancy of Ageing. Journal of Ethnic and Migration Studies 33:2, 275-297.

Baldassar, L., C.V. Baldock \& R. Wilding 2007: Families Caring Across Borders: Migration, Ageing and Transnational Caregiving. Houndmills, UK: Palgrave Macmillan.

Brah, A. 1996: Cartographies of Diaspora: Contesting Identities. London: Routledge.

Brennan, D. 2004: What's Love Got to Do with it? Transnational Desires and Sex Tourism in the Dominican Republic. Durham, NC: Duke University Press.

Bryceson, D.F. \& U. Vuorela, 2002: Transnational Families in the Twenty-First Century. In: D. F. Bryceson \& U. Vuorela (eds.), The Transnational Family: New European Frontiers and Global Networks. Oxford \& New York: Berg, pp. 3-30.

Caglar, A. 1997: Hyphenated Identities and the Limits of 'Culture': Some Methodological Queries. In: P. Werbner $\&$ T. Madood (eds.), The Politics of Multiculturalism in the New Europe: Racism, Identity, Community. London: Zed Publications.

Cairncross, F. 1997: The Death of Distance. London: Orion.

Dreby, J. 2006: Honor and Virtue: Mexican Parenting in the Transnational Context. Gender and Society 20, 32-60.

Elias, N. 2000: The Civilizing Process. Trans. E. Jephcott, rev. ed. Oxford: Blackwell.

Erel, U. 2002: Reconceptualizing Motherhood: Experiences of Migrant Women from Turkey Living in Germany: In: D.F. Bryceson \& U. Vuorela (eds.), The Transnational Family: New European Frontiers and Global Networks. Oxford \& New York: Berg, pp. 127-146.

Faist, T. 2000: The Volume and Dynamics of International Migration and Transnational Social Spaces. Oxford: Clarendon.

Fischer-Rosenthal, W. \& G. Rosenthal 1997: Narrationsanalyse biografischer Selbstpräsentation. In: R. Hitzler \& A.
Honer (eds.), Sozialwissenschaftliche Hermeneutik: Eine Einführung. Opladen: Leske + Budrich, pp. 133-164.

Fog Olwig, K. 2003: 'Transnational' Socio-Cultural Systems and Ethnographic Research: Views from an Extended Field Site. International Migration Review 37:3, 787-811.

Gamburd, M.R. 2000: The Kitchen Spoon's Handle: Transnationalism and Sri Lanka's Migrant Housemaids. Ithaca, NY \& London: Cornell University Press.

Harvey, D. 1990: The Condition of Postmodernity: An Enquiry into the Origins of Cultural Change. Oxford \& Malden, MA: Blackwell.

Hondagneu-Sotelo, P. \& E. Avila 1997: 'I'm here, but I'm there': The Meanings of Latina Transnational Motherhood. Gender and Society 11:5, 548-571.

Kearney, M. 1995: The Local and the Global: The Anthropology of Globalization and Transnationalism. Annual Review of Anthropology 24, 547-565.

Kofman E. \& R. Sales 1998: Migrant Women and Exclusion in Europe. The European Journal of Women's Studies 5:3-4, 381-398.

Levitt, P. 2001: The Transnational Villagers. Berkeley: University of California Press.

Levitt, P. \& N. Glick Schiller 2004: Conceptualizing Simultaneity: Theorizing Society from a Transnational Social Field Perspective. International Migration Review 38:3, 1002-39.

Licoppe, C. 2004: 'Connected' Presence: The Emergence of a New Repertoire for Managing Social Relationships in a Changing Communication Technoscape. Environment and Planning D: Society and Space 22, 135-156.

Lutz, H. 2008: Vom Weltmarkt in den Privathaushalt: Die neuen Dienstmädchen im Zeitalter der Globalisierung. Opladen: Budrich.

Lutz, H. 2011: The New Maids: Transnational Women and the Care Economy. Trans. D. Shannon. London \& New York: Zed.

Mahler, S. 1998: Theoretical and Empirical Contributions: Towards a Research Agenda for Transnationalism. In: M.P. Smith \& L.E. Guarnizo (eds.), Transnationalism from Below. New Brunswick, NJ: Transaction Publishers, pp. 64-100.

Massey, D. 1993: Power-Geometry and a Progressive Sense of Place. In: J. Bird, B. Curtis, T. Putnam, G. Robertson \& L. Tickner (eds.), Mapping the Futures: Local Cultures, Global Change, London: Routledge, pp. 59-69.

Momsen, J. Henshall 1999: Maids on the Move. In: J. Henshall Momsen (ed.), Gender, Migration and Domestic Service. London \& New York: Routledge.

Morokvasic, M. 1999: La mobilité transnationale comme ressource: Les cas des migrants de l'Europe de l'Est. Cultures et Conflits 33-34, 105-122.

Nyberg Sørensen, N. \& K. Fog Olwig 2002: Work and Migration: Life and Livelihood in a Globalizing World. London \& New York: Routledge. 
Oz, A. (2002) 2004: A Tale of Love and Darkness. Trans. N. de Lange. London \& New York: Harcourt.

Parrenas, R.S. 2001: Servants of Globalization: Women, Migration and Domestic Work. Stanford: Stanford University Press.

Parrenas, R.S. 2005: Children of Global Migration: Transnational Families and Gendered Woes. Stanford: Stanford University Press.

Pries, L. 1998: Transnationale soziale Räume: Theoretischempirische Skizze am Beispiel der Arbeitswanderungen Mexiko-USA. In: U. Beck (ed.), Perspektiven der Weltgesellschaft. Frankfurt am Main, pp. 55-87.

Rogers, A. 2004: A European Space for Transnationalism? In: P. Jackson et al. (eds.), Transnational Spaces. London: Routledge, pp. 164-182.

Sayad, A. 2004: The Suffering of the Immigrant. Trans. D. Macey. Cambridge \& Malden, MA: Polity Press.

Schmalzbauer, L. 2004: Searching for Wages and Mothering from Afar: The Case of Honduran Transnational Families. Journal of Marriage and Family 66, 1317-31.

Schütze, F. 1983: Biographieforschung und narratives Interview. Neue Praxis 3, 283-293.

Thomas, W.I. \& F. Znaniecki (1918)1984: The Polish Peasant in Europe and America. Ed. E. Zaretsky. Chicago: University of Illinois Press.
Urry, J. 2003: Networks, Travel and Talk. British Journal of Sociology 54:2, 155-175.

Vertovec, S. 2004: Cheap Calls: The Social Glue of Migrant Transnationalism. Global Networks 4:2, 219-224.

Vuorela, U. 2002: Transnational Families: Imagined and Real Communities. In: D.F. Bryceson \& U. Vuorela (eds.), The Transnational Family: New European Frontiers and Global Networks. Oxford \& New York: Berg, pp. 63-82.

Wilding, R. 2006: Virtual Intimacies. Global Network 6:2, 125-142.

Yans-McLaughlin, V. (ed.) 1990: Immigration Reconsidered: History, Sociology, and Politics. Oxford \& New York: Oxford University Press.

Karen Körber is a research fellow at the Jewish Museum Berlin. Her publications include books and articles on transnationalism, Jewish diaspora, migration and identity politics. A recent article is "Nähe auf Distanz: Transnationale Familien in der Gegenwart” (in Gertraud Marinelli-König \& Alexander Preisinger, eds., 2011, Zwischenräume: Migration und die Entgrenzung von Kulturen und Identitäten. Bielefeld: Transcript).

(k.koerber@jmberlin.de) 


\title{
“THE DAUGHTERS HAVE GROWN UP” Transnational Motherhood, Migration and Gender among Catholic Nuns
}

\author{
Gertrud Hüwelmeier
}

\begin{abstract}
This article explores transnational spiritual motherhood in women's congregations from a historical and anthropological perspective, considering the question as to how ideas of motherhood have changed across geographic borders and over an extended period of time. Within a religious context, kinship terms (mother, sister, daughter) are based not on biological, but on ritual relationships. In the past, social contact to biological parents and to the family of origin was reduced to a minimum or cut off entirely when a young woman entered a religious congregation. In view of the transnationalization of convent life and the accompanying increased mobility of Catholic sisters, this presents new challenges for many religious orders.
\end{abstract}

Keywords: transnational motherhood, Catholic nuns, migration, mobility, Europe, United States

As early as the nineteenth century, especially due to the migration movements from Europe to the United States, thousands of Catholic nuns were separated from their mother houses, and thus also from their "mothers", the founders of the respective women's congregations. Despite the spatial separation, the sisters were pioneers of female migration, maintaining transnational connections to their places of origin on the other side of the Atlantic. As spiritual mothers, the founders of these communities worried about their "daughters" living so far away.

Transnational motherhood is by no means a phenomenon of the twenty-first century. Although a growing number of mothers presently live separated from their children (Hondagneu-Sotelo \& Avila 1997; Hoang \& Yeoh 2011; Hüwelmeier 2013a), motherhood across geographic and cultural borders existed in earlier centuries and in various different societies, including mobile Catholic sisters, whom I have referred to as pioneers of female migration (Hüwelmeier 2005a; Hüwelmeier 2005b). Based on ethnographic fieldwork with the Poor Handmaids of Jesus Christ (PHJC), a globally interconnected women's congregation, I will illustrate how ideas of spiritual and social motherhood have changed over the course of a 150-year period and across continents. ${ }^{1}$ In line with Carling, Menjivar and Schmalzbauer (2012: 192), I argue that physical absence is compatible with social and emotional presence and participation.

In the first part of this article I will sketch new approaches to transnational motherhood, a phenomenon that is gaining significance in view of recent migration movements and new communica- 
tion technologies. This also involves re-evaluating the traveling activities of women who had already crossed geographic and territorial boundaries in the nineteenth and early twentieth centuries, long before anthropological research started speaking of globalization or global flows (Appadurai 1996; Hannerz 1996). I will then discuss the dynamic relationship between gender, migration and mobility. Further, I describe the bidding of farewell to "mothers" by focusing on traveling nuns, and depict tensions and conflicts between "mothers", "co-mothers" and "daughters" beyond borders. Transatlantic communication is also a main aspect of the historical and anthropological perspective on transnational motherhood.

Based on multi-sited ethnography, in the next section I will discuss the processes of transformation and the new way of looking at social motherhood in women's congregations since the 1960s. Hierarchy and power relations were increasingly questioned in Catholic religious orders as well as in other "total institutions" (Goffman 1961). The women's movement, students' movement and the young Indian and African women who joined women's congregations with a "Western" orientation in the 1960s all contributed to cracking the image of dominant mother superiors.

\section{Co-parenthood and Transnational Motherhood}

My understanding of transnational motherhood is not reduced to the relationship of mothers living in the diaspora to their minor-age children in the country of origin. Instead, I view the concept of transnational motherhood as an enduring relationship between people of different generations in different countries. Thus it is independent of age and can also exist among adults (see also Åkesson, Carling \& Drotbohm 2012: 239). My analysis of transnational connections between Catholic nuns and their "mothers" focuses on social and spiritual motherhood as a kind of fictive or ritual kinship relation. Configurations of co-parenthood have long had great significance in anthropology, in particular with regard to the expansion of social and political networks, such as kivrelik in the Turkish context
(Kudat-Sertel 1971: 37) or compadrazgo, a relationship between parents and godparents that is maintained in Spain and in many Latin American countries (Mintz \& Wolf 1950). In addition to biological parents, co-parents also assume responsibility for children or adolescents. It is not unusual for coparents to live at different locations. Esther Goody (1982) has shown that many children in West Africa do not grow up in their families of origin, but are brought to relatives or friends living elsewhere, who then raise the children. Sometimes these "new" parents live in different countries or even continents. Older siblings can also assume responsibility. In some African countries, for example - as a consequence of AIDS/HIV - orphans grow up in households run by other children. In these child-headed households, older siblings or underage relatives take on the role of the mother (Wolf 2010).

Practices of co-parenthood are as well known in European countries. From the mountainous regions of Austria, for example, into the 1930s "illegitimate" children of servants and maids, working as farm laborers, were not allowed to remain living with their parents if the parents did not want to risk losing their place of employment. Thus parents sought other options and asked "foster" parents to take care of their children. In general, foster parents (Zieheltern) were couples, friends or relatives, who either had their own children but needed more workers or were without children and subsequently had no heir for the farm. Foster parents often lived nearby, either in the next valley or a few hours away on foot, but without means of transportation the walking distances were a difficult endeavor. Another kind of co-parenthood is known from the so-called Swabian children. With their parents' consent children between five and fourteen were sent from the Tyrol and Vorarlberg areas of Austria to work as maids and servants for farmers they did not know in Upper Swabia (Lampert 1996).

Children who travel on their own, without parents or co-parents, are today looked after as unaccompanied minors by state institutions in European societies. The majority of minors not living with their parents, however, live with co-parents. In my current 
research on transnational Vietnamese families in Berlin, some children and adolescents below eighteen live with relatives who have already resided in Germany for some time. Their parents in Vietnam want them to have a better life than their own and entrust them in the migration context to the care of their uncles, aunts, or older cousins. Young women from Vietnam who work as domestic workers or nannies in Germany make up another group. On the one hand these are situations in which minors are exploited, since many of these women are irregular migrants and totally dependent on their "employers". On the other hand, this offers young women from Vietnam their only chance to leave their country of origin and live in Germany "without papers", with the possibility of finding new, more long-term prospects.

\section{Gender, Migration and Mobility}

In many societies, female migrants have ideas of "good motherhood" that are characterized by caring practices for their children. Due to the mobility of mothers, relatives such as the father, uncle and aunt or grandparents take care of the children (Erel 2002). Mothers who leave their families behind to work as nurses or domestic workers (Liebelt 2011) are able to stay in contact with their partners and children thanks to modern communication technologies. In the late 1980s these options were still very limited, in socialist societies in particular. For example, many female Vietnamese contract workers in East Germany (GDR) lived separated from their families in Vietnam (Hüwelmeier 2013a). Thousands of mothers and fathers had to leave their children behind in Vietnam. Due to bilateral agreements between the Socialist Republic of Vietnam and East Germany, contract workers were not permitted to bring their children with them. Whereas in the early 1980 s stateowned Vietnamese companies started "delegating" primarily "singles", that is, unmarried people, to Russia, East Germany and other socialist countries, in the late 1980s the Socialist Republic of Vietnam had to resort to sending married people (with children who had to be left in Vietnam) in order to cover the increased demand for labor in "socialist brother countries". By sending just one spouse, there was a high probability that this person would return to the home country and not stay in the GDR. Already at that time some parents tried to bring their children into East Germany from Vietnam (Hüwelmeier 2013a), but these efforts failed due to bureaucratic obstacles and the state control. Not only mothers, but also fathers suffered from spending years living away from their children and spouse. Furthermore, as Hoang and Yeoh mentioned, notions of masculinity change when fathers have sole responsibility for raising their children (Hoang \& Yeoh 2011).

Migrants, both men and women, will continue to care for the emotional and physical well-being of their children. In particular, they try to provide money for them to receive good education and/or training ( $\AA$ kesson, Carling \& Drotbohm 2012: 239). In cases of female migration, financial responsibility for the children often lies with the mothers, who also send remittances for the rest of the family. Simultaneously, mothers are primary caretakers for their children. In many cases, mothers have daily contact with their children, talking on the phone or via Skype, discussing school problems, the latest fashion news or conflicts with friends.

\section{Traveling Nuns}

Romanticizing and idealizing notions of motherhood in Western European societies can be traced back to the bourgeois milieu of the nineteenth century. Women in religious congregations are an excellent example of the fragility of such ideas. Female Catholic congregations in particular opened doors for many young women to live out their own ideas of professional work beyond the bourgeois perceptions of the family and without the protective hand of a father or husband. At the same time they could organize their daily lives as well as their religious lives in a community with other women. In women's congregations that were founded around 1850, Catholic sisters who became active nuns (i.e., not contemplative), made a clear decision for professional work as a nurse, a midwife, a teacher, and against the ideal of the bourgeois housewife and mother (Hüwelmeier 2004; Meiwes 2000).

One of the most pressing responsibilities of the 
"good mothers" who founded women's congregations was to provide for their "daughters" to receive qualified training once they had bid a final farewell to their families of origin. Qualified specialists were urgently needed as home nurses and later as nurses in newly established hospitals (Meiwes 2008). As teachers and carers in nursery schools, women religious assumed the task of partly replacing biological mothers: Women working as industrial workers could thus earn a living because the sisters cared for and raised their children. This is why the Poor Handmaids of Jesus Christ (PHJC) had already migrated in the last three decades of the nineteenth century from Germany to the working-class districts of London. They followed German migrants who had found work in London, and taught their children. Other PHJC sisters lived and worked in villages in the Westerwald region, north of Frankfurt am Main, caring for children who were left alone at home during the day because their mothers had to work in the fields. The fathers left the villages to work as seasonal labor migrants (Hüwelmeier 2000) and did not return to their homes until late autumn. A considerable number of sisters became co-mothers, which thus enabled many women to contribute to the family's livelihood as factory workers or smallholders. Still, some Catholic sisters left Europe and traveled to the United States as early as the nineteenth century.

Among the many women who migrated from $\mathrm{Eu}$ rope to the United States in the second half of the nineteenth century were thousands of Catholic nuns. I cannot go into detail here about their motivation for emigrating, how they experienced their departure or their impressions upon arriving and becoming incorporated into the host society (Hüwelmeier 2005b), as the subject of this article is constructions of motherhood in transnational settings. The theoretical question, however, is not directed at the process of migration as a unidirectional movement; instead, I would like to concentrate on recent concepts of transnational migration and maintaining contact between two or more countries (Hüwelmeier 2010, 2009a, 2009b, 2008a, 2008b; Gabaccia 2000).

Since most of the women's congregations that were founded in Europe in the nineteenth century still exist today, it is relevant to ask how crossborder relations have been maintained over several generations. As early as 1850 Catholic sisters left their hometowns in Europe, finding their own way in American society, which was totally foreign to them, largely without any male support. Priests and bishops were often not present at all in very remote rural areas. Male representatives of the Catholic Church, however, played a prominent role in sending the first sisters on their journey. From a gender perspective, the concept of transnational motherhood poses the question whether women religious, frequently perceived as "daughters" by female founders of the congregations, enjoyed greater independence from their "mothers" in Europe while living abroad. Recent debate and empirical research on transnationalism have shown that theories on migration that focus on assimilation and adaptation to the host society must be criticized for not adequately taking into account the everyday experiences of migrants (Levitt \& Glick Schiller 2004). It has instead turned out that individuals and groups who left their home countries for either voluntary or coerced migration still participate in activities in their society of origin, whether by participating in political issues, by trading, by founding and supporting religious networks (Levitt 2007; Hüwelmeier 2011) or by maintaining regular, long-term contact with their extended networks of relatives. In any case, farewells as rituals of separation are among the emotional experiences of migrants. In the following, I will first describe the departure of the "daughters" from the female founder of the PHJC. Then I will explore how motherhood is maintained beyond national borders and discuss the tensions that may emerge between spiritual mother (the female founder), spiritual co-mothers, and "new daughters".

\section{Separation from the Spiritual Mother}

As early as 1868 the first sisters of the PHJC crossed the Atlantic to the United States, as migration from Europe to North America brought a great demand for nurses and teachers among the Ger- 
man population settled there. Katharina Kasper, founder of the PHJC and referred to as "Mother", encouraged her "children", as she called the sisters, to build new branches in the United States. She nevertheless had a close and at the same time very responsible relationship with them. The way she personally said goodbye to her "daughters" is evidence of her emotional attachment. She even traveled with them to the port in France, from where they set sail for the United States. Eight nuns from Germany were accompanied to Le Havre (France) by the Reverend Mother, which is how she was referred to in virtually all texts from that time. It was not planned that the "children" would return. Katharina Kasper reported to the sisters in the German mother house on the departure of the eight as follows:

When we said goodbye at the port, we promised to greet them one more time at the waterfront, where they again received priestly blessings from several priests, and the sisters had to sing: Guide us through the waves. And then it went into the open sea, and the poor children were allowed to cry. But, my beloved sisters, what a moving sight it was, the great sea, the terrible waves, the quick departure of the ship. The poor sisters were out of sight. Now I too could cry and watch the ship for a long time, until we could not see it anymore... ${ }^{2}$

This letter expresses her sadness that the "children" were no longer nearby, possibly also the idea that she would never see them again. In addition, the author reveals something to her readers about her emotions, which kept her standing there watching until she could no longer see her departing daughters (Hüwelmeier 2005a). Only then did she allow her tears to flow. It was presumably embarrassing for her to cry in the presence of her "children". This text passage is exemplary of the significance of the emotional implications of life in a transnational setting, which, as Louise Ryan remarked (Ryan 2011), has not yet been thoroughly researched.

\section{Cross-Border Relations}

Arrival in the United States was not only characterized by new living and working conditions, but the sisters also had to learn the language of the country. Further, they had to understand a different political culture and develop a modified concept of hierarchy in their small communities. What kind of relationship did the "daughters" maintain to the "mother" in Germany? Who were their contact persons in the United States? Who made decisions? How did power relations function among women?

Maintaining the social and political order of any religious order is based on compliance with the constitutions and the vows of poverty, chastity and obedience taken (Hüwelmeier 2004). Superiors were and are appointed to monitor the upholding of the congregation, with a house superior for each local community, a regional superior for the respective region, a provincial superior for the province and at the highest level authority was exercised by the Spiritual Mother, founder of the religious congregation, and later by her successors, the General Superiors. Already in the nineteenth century, regional and provincial superiors frequently traveled back and forth in their respective "domains", regularly visiting the scattered convents of the sisters. The chronicles show numerous references to these journeys, which sometimes lasted several days or even weeks (Hüwelmeier 2008b).

Due to the difficulty and expense of travel, transatlantic meetings were rather rare in the nineteenth century. Only on special occasions were delegations from the mother house in Germany sent to the United States. In 1872 a sister from Germany arrived as a visitor to Fort Wayne, Indiana, along with six other sisters who were to remain in the United States as "reinforcements". As representative of the Reverend Mother the sister inspected all US branches and simultaneously assumed office as provincial superior in the United States. The incumbent provincial superior then returned to Germany. In subsequent years more and more branches were founded in the United States, thus increasing the travels of the provincial superior. 
From 28th March until 10th April the Reverend Sisters Secunda accompanied by Sister Hyacintha visited the branches in Ashland and New Ulm. On 20th April the Rev. Sister Secunda traveled to Chicago .... From 1st to 12th May the Rev. Sister Secunda stayed in the branch houses of Germantown, Carlyle and Trenton.... ${ }^{3}$

Striking about this quote is the designation of the highest authority, the spiritual co-mother in the United States, as "Reverend Sister". Reverend Sister is distinguished from Reverend Mother in that the former had assumed a position of power in the United States, whereas the Reverend Mother, as founder of the community in Europe, was in charge of all branches. To safeguard the power and authority of the Generalate in Europe, close contact between the US branches and the German mother house was indispensable. Transatlantic relations and the maintenance of the "German spirit" of the PHJC in the United States were guaranteed, first of all, through the "reinforcements" sent from Germany. But German sisters in the United States also paid visits to Germany. Although these trips were few and far between, they helped create and maintain a transnational consciousness, strengthening the community's collective identity.

On 19th May the Reverend Sister Secunda, together with Sisters Hyacintha, Suitberta and Anasthasia, took a trip to visit the beloved mother house in Dernbach. After a pleasant crossing the sisters were greeted upon their arrival at the mother house with heartfelt love and joy by the Reverend Mother and the reverend assistants and sisters and showered with all possible attention. They were most joyous to find the Reverend Mother even healthier and heartier than her age and previous strenuous efforts would have let them anticipate. After the spiritual exercises and the holding of the general chapter, the sisters returned to America. Sister Suitberta remained according to her wishes in Europe, and in turn three novices were sent with the others to America. On 2nd August the sisters arrived safe and sound back at the provin- cial mother house in Fort Wayne, where they were most cordially received by the sisters. ${ }^{4}$

This passage illustrates that transnational connections were not unidirectional, but encompassed two or more countries. In the nineteenth century sisters in women's congregations in Germany established not only transatlantic meetings and contact, but in addition also built up branches in the Netherlands and England.

\section{When "Daughters" Leave}

Not all "daughters" living in the United States wanted to uphold the "German spirit" of the community. Some strove to break off from the German mother house and found their own community. One German provincial superior was called back to Germany in the early 1880s because she had made some decisions independently, without the approval of the Mother (Hüwelmeier 2005a). In some cases the leadership took drastic measures and dismissed some sisters, although they had been members of the community for many years.

In 1889 we experienced a very regrettable incident, namely, the necessity to dismiss a sister who had already been a member of the congregation for eighteen years. After Sister Klara had already often caused disturbances of the peace, conducted herself improperly towards her Mother Superior and finally had tried to talk other sisters into leaving the congregation for the purpose of founding a new community, the Reverend Sister Secunda thought it would be best in avoiding any greater damage to present the case to the Most Reverend Bishop. He decided that Sister Klara had to be dismissed, which then happened on 6th March. ${ }^{5}$

The text passage indicates that in some cases the "Father", represented in the figure of the bishop, was consulted. This was not always the case, as there were times when gender conflicts beyond borders, between spiritual mothers and fathers - that is, between women as founders of congregations and bishops - seemed insurmountable (Hüwelmeier 
2005a). In addition to cross-border gender conflicts between "parents" there was also tension among German sisters in the United States. Some of them feared that the young American sisters who joined the congregation would deviate from the "German" course and, with support of the provincial superior, establish a separate community in the United States. This can ultimately be referred to as transnational "sibling conflicts" or generational conflicts.

\section{Communication beyond Borders}

Communication between parents and their children living far apart from each other is "intimately linked with communication technologies" (Carling, Menjivar \& Schmalzbauer 2012: 204). This also applies to transnational sisters and their "mothers". In the nineteenth century relationships were kept up beyond borders especially by letter writing and later via telegrams. Although the "Mother", General Superior of the PHJC, could not visit the branches in the United States for health reasons, she traveled to America several times per day in her prayers. These spiritual journeys strengthened the bonds between her and her "daughters". In the letters that she sent to the United States, she expressed her regrets that she could not be there in person, but at the same time she assured her "children" that she was always thinking about them. She urged them to obey the rules, that is, the constitutions, and to remain good Handmaids of Jesus Christ.

Although we are physically separated, through our sacred profession and the spirit of the poor handmaids of Jesus Christ we are very closely united with one another, so that no one can speak of a separation due to the ocean. ${ }^{6}$

Through her letters she maintained not only continuous contact, but also attempted to create a united community by emphasizing the collectivity and a shared consciousness. Even if the founder of the women's congregation was not able personally to get to know the United States, she, like her "children", was part of a "transnational social field" (Levitt \& Glick Schiller 2004), thus belonging to the large group of people whose lives are influenced by the migration of people close to them and by the upholding of social relations and emotional ties to those living far away.

Tension arose time and again over decades between German general superiors and American provincial superiors. But the geographic distance between the United States and Europe was too great for the German Generalate to be able to exert any sustained influence on the "daughters" in the United States over several generations and an extended period of time. German-American sisters, especially since the First World War and the start of anti-German sentiments in the United States, led relatively independent lives on the other side of the ocean. Not until the 1960s did transatlantic relations experience a kind of revival.

\section{"The Daughters Have Grown Up"}

After the Second Vatican Council (1962-65) introduced the reform process in the Catholic Church, cautious protest initially emerged in the American provinces with regard to the dominance of the German mother house. For decades, as I discovered during my ethnographic fieldwork with American sisters, attempts were made again and again to contain the German influence. After 1965 the major discussion on the issue of the habit and civilian dress was sparked in many religious congregations in the United States, whereas in Germany the debate was conducted on the quiet. American and also Dutch sisters told me that they have long since lived in their home countries wearing civilian clothing and without a habit, although this was not permitted by the German General Superior (who into the 1970s was still referred to as "Mother"). When they traveled to Germany, however, to visit the Reverend Mother and participate in conferences of the community, they brought their habit with them and changed clothes in the aeroplane. They would put on their headpiece as soon as they arrived at the mother house.

When in the course of my fieldwork in the 1990s I asked a superior in Germany why the term "Mother" was abandoned in the 1970s, she explained not without pride that "the daughters have grown up". In her 
view it was no longer appropriate for superiors to treat adult women in a patronizing manner. Many sisters had entered the congregation in the 1950s and around the period of Vatican II with great hopes for change in the Catholic Church and thus also in women's congregations. They wanted to articulate and discuss their own ideas of living together in a religious community. In this article I cannot go into the diversity of processes of democratization in many convents, but the debate on the habit was just a small part of it (Hüwelmeier 2004).

The arrival of Indian sisters in Germany between 1963 and 1970, traveling in several cohorts, had a far more sustained influence. Most of their German peers referred to them as "children" who needed protection, as young women who should not be overburdened or given any responsibility whatsoever. After the Indian sisters had lived and worked in Germany for more than ten years, they returned to India to found new branches. They did not travel alone, however, but were accompanied by a German "mother" who took care of all the arrangements, especially maintaining contact with the German mother house. In the 1970s that was not an easy matter. Sister Maria, as I call her here, was appointed a Superior by the Generalate; she was not elected by the Indian sisters. In Bangalore, India, she purchased real estate with the financial backing of the German mother house, collected donations and had a large building built that accommodated all the sisters in India. As "mother" she felt responsible for the well-being of the Indian sisters as well as for the growth of the community in India. Many new convents were opened between 1970 and 2000 throughout India. Indian sisters built schools, orphanages, boarding schools and specialized tuberculosis hospitals. In particular they actively supported women's and children's rights.

Since the 1990s the Indian sisters have become increasingly self-confident, but even many years after returning to India they did not become independent. They still relied on financial support from the German mother house and Sister Maria still held a leadership position, watching over the hygiene regulations in the main convent, and disapproving of the Indian sisters' eating with their hands. German meals were always cooked especially for her. Even though she was very outspoken regarding the affairs of the PHJC in India, Indian sisters imagined themselves not as "daughters", but as independent women who were treated patronizingly now and then. After prolonged debate over many years within the entire community of the congregation, Indian sisters were ultimately granted greater independence from the mother house in Germany. In 2000 they founded their own "province". In other words, since that time they elect their own leadership teams, but like all the other provinces they continue to be under the auspices of the Generalate, which has meanwhile become international, with its headquarters in Germany. After all, the Indian daughters, too, have grown up.

\section{Conclusion: Transnationalization of Convent Life}

The call of Vatican II to renew or "modernize" the Catholic Church contributed in many women's congregations to a new focus in their social work, namely to a greater involvement in so-called developing countries. Many of the communities established in Europe in the nineteenth century had not perceived themselves as a missionary order. However, this changed after Vatican II, when a number of women's congregations invited women from Asia, Africa and Latin America to join their communities.

In the following decades the multi-ethnic presence contributed to a transformation of everyday life in the convents, to a new orientation in the work of the sisters and generally to a process that I have referred to as the transnationalization of convent life (Hüwelmeier 2013b). With that I mean the creation and maintenance of social and religious networks beyond geographic and cultural borders. Crossing cultural spaces generates new mobilities and greatly influences the traveling activities of sisters, many of whom had previously never been to Asia or Africa. Finally, the transnationalization of convent life has contributed to the abandonment of the concept of the mother. Processes of breaking down hierarchies can be observed in many convents and processes 
of democratization in women's congregations, in which particularly women from non-European societies are granted an equal voice, making the concept of the mother superfluous and at the same time strengthening the idea of sisterhood.

Presently, more and more convents are made up of women from diverse ethnic, national and linguistic backgrounds. In India, small communities are consciously mixed with sisters of different ages, languages, and countries of origin. These ways of living together, according to sisters, contribute to better mutual understanding. Ultimately the sisters create what they refer to as "lived internationalism". For these reasons they no longer need spiritual mothers, since they have all grown up.

The biological parents of Catholic sisters have recently received increased attention. If a mother or father is sick or dying, the sisters are encouraged by the leadership team to travel to their hometowns, also for extended periods of time. Whereas a hundred and fifty years ago nuns either broke off contact with their parents entirely or reduced it to a minimum, sisters now assume that the emotional contact to biological parents and siblings is generally beneficial and positive for convent life. Sisters from India working in Germany regularly spend their holidays in India in order to visit their mother, father, and other relatives. In this way they do not differ at all from many women in transnational families who, depending on their financial options, take trips to their places of origin to care for their sick or aging parents.

\section{Notes}

1 This article is based on multi-sited fieldwork in a transnational women's congregation. Empirical research for the Transnational Religion project was conducted between 2000 and 2005, financed by the German Research Foundation (DFG, Transnational Religious Networks, HU 1019/2-1 and HU 1019/2-2). Based on historical documents from various archives and anthropological fieldwork in convents in Germany, the Netherlands, England, the United States and India, I examined the creation and maintenance of cross-border relations in the past and present.

2 Letter by Katharina Kasper of 15 August 1868. Archives of the PHJC mother house in Dernbach, Westerwald. In: Gottfriedis Amend, ADJC 2001, 73.
3 Chronicle of the American province. Archives of the ADJC (PHJC), Dernbach mother house, entry: 1889.

4 Chronicle of the American province. Archives of the ADJC (PHJC), Dernbach mother house, entry: 1889.

5 Chronicle of the American province. Archives of the ADJC (PHJC), Dernbach mother house, entry: 1889.

6 Letter by Katharina Kasper of 17 December 1887. In: Gottfriedis Amend, ADJC 2001, 389.

\section{References}

Åkesson, Lisa, Jørgen Carling \& Heike Drotbohm 2012: Mobility, Moralities and Motherhood: Navigating the Contingencies of Cape Verdean Lives. Journal of Ethnic and Migration Studies 38:2, 237-260.

Amend, Gottfriedis, for the Generalate of the Poor Handmaids of Jesus Christ (ADJC), 2001: Katharina KasperGründerin der Kongregation der Armen Dienstmägde Jesu Christi. Schriften, vol. 1: Erste Regeln und eigenhändige Briefe. Kevelaer: Verlag Butzon \& Bercker.

Appadurai, Arjun 1996: Modernity at Large: Cultural Dimensions of Globalization. Minneapolis, MN: University of Minnesota Press.

Carling, Jørgen, Cecilia Menjivar \& Leah Schmalzbauer 2012: Central Themes in the Study of Transnational Parenthood. Journal of Ethnic and Migration Studies 38:2, 191-217.

Erel, Umet 2002: Reconceptualizing Motherhood: Experiences of Migrant Women from Turkey Living in Germany. In: Deborah F. Bryceson \& Ulla Vuorola (eds.), The Transnational Family: New European Frontiers and Global Networks. Oxford \& New York: Berg, pp. 127-146.

Gabaccia, Donna R. 2000: Italy's Many Diasporas. London: University College London Press.

Goffman, Erving 1961: Asylums: Essays on the Social Situation of Mental Patients and Other Inmates. Chicago: Aldine Publishing.

Goody, Esther N. 1982: Parenthood and Social Reproduction: Fostering and Occupational Roles in West Africa. Cambridge: Cambridge University Press.

Hannerz, Ulf 1996: Transnational Connections: Culture, People, Places. London: Routledge.

Hoang, Lan Anh \& Brenda S.A. Yeoh 2011: Breadwinning Wives and 'Left-Behind' Husbands: Men and Masculinities in the Vietnamese Transnational Family. Gender \& Society 25:6, 717-739.

Hondagneu-Sotelo, Pierette \& Ernestine Avila 1997: 'I'm here, but I'm there': The Meanings of Latina Transnational Motherhood. Gender \& Society 11:5, 548-571.

Hüwelmeier, Gertrud 2000: Gendered Houses: Kinship, Class and Identity in a German Village. In: Victoria Ana Goddard (ed.), Gender, Agency and Change: Anthropological Perspectives. London: Routledge, pp. 122-141.

Hüwelmeier, Gertrud 2004: Närrinnen Gottes: Lebenswelten von Ordensfrauen. Münster: Waxmann Verlag. 
Hüwelmeier, Gertrud 2005a: Ordensfrauen unterwegs: Transnationalismus, Gender und Religion. Historische Anthropologie 13:1, 91-110.

Hüwelmeier, Gertrud 2005b: 'Nach Amerika!' Schwestern ohne Grenzen. L'Homme: Europäische Zeitschrift für Feministische Geschichtswissenschaft 16:2, 97-115.

Hüwelmeier, Gertrud 2008a: Formations of the Religious Self-Becoming 'Women in Christ' in a Globalizing World. In: Heike Bock, Jörg Feuchter \& Michi Knecht (eds.), Religion and Its Other: Secular and Sacral Concepts and Practices in Interaction. Frankfurt am Main \& New York: Campus, pp. 199-211.

Hüwelmeier, Gertrud 2008b: Nonnen auf Reisen - Transnationale Verflechtungen. In: Susann Baller, Michael Pesek, Ruth Schilling \& Ines Stolpe (eds.), Die Ankunft des Anderen. Frankfurt a. M. \& New York: Campus, pp. 226-233.

Hüwelmeier, Gertrud 2009a: Global Sisterhood: Transnational Perspectives on Gender and Religion. In: Ann Braude \& Hanna Herzog (eds.), Gendering Religion and Politics: Untangling Modernities. New York: Palgrave Macmillan, pp. 173-190.

Hüwelmeier, Gertrud 2009b: Women's Congregations as Transnational Social Security Networks. In: Carolin Leutloff-Grandits, Anja Peleikis \& Tatjana Thelen (eds.), Social Security in Religious Networks: Anthropological Perspectives on New Risks and Ambivalences. Oxford \& New York: Berghahn, pp. 187-205.

Hüwelmeier, Gertrud 2010: Female Believers on the Move: Gender and Religion in Vietnamese Pentecostal Networks in Germany. In: Glenda Lynna Anne Tibe Bonifacio \& Vivienne Angeles (eds.), Gender, Religion and Migration: Pathways of Integration. Lanham, MD: Lexington Books, pp. 115-131.

Hüwelmeier, Gertrud 2011: Socialist Cosmopolitanism Meets Global Pentecostalism: Charismatic Christianity among Vietnamese Migrants in Germany. In: Tsypylma Darieva, Nina Glick Schiller \& Sandra Gruner-Domic (eds.), Cosmopolitan Sociability: Locating Transnational Religious and Diasporic Networks. Ethnic and Racial Studies (Special Issue) 34:3, 436-453.

Hüwelmeier, Gertrud 2013a: The 'Children of Uncle Ho' - Socialist Cosmopolitans in East Germany. In: Katrin Hansing \& Maxim Matusevich (eds.), Socialist Migrations during the Cold War. Basingstoke: Palgrave Macmillan (forthcoming).

Hüwelmeier, Gertrud 2013b: 'Our future will be in India':
Traveling Nuns between Europe and South Asia. In: Ester Gallo (ed.), Migration and Religion in Europe: Comparative Perspectives on South Asian Experiences. Farnham: Ashgate (forthcoming).

Kudat-Sertel, Ayse 1971: Ritual Kinship in Eastern Turkey. Anthropological Quarterly 44, 37-50.

Lampert, Regina 1996: Die Schwabengängerin, ed. Bernhard Tschofen. Zürich: Limmat.

Levitt, Peggy 2007: God Needs No Passport. New York: The New Press.

Levitt, Peggy \& Nina Glick Schiller 2004: Conceptualizing Simultaneity: A Transnational Social Field Perspective on Society. International Migration Review 38, 1002-1039.

Liebelt, Claudia 2011: Caring for the Holy Land: Transnational Filipina Domestic Workers in the Israeli Migration Regime. Oxford \& New York: Berghahn.

Meiwes, Relinde 2000: Arbeiterinnen des Herrn: Katholische Frauenkongregationen im 19. Jahrhundert. Frankfurt am Main \& New York: Campus.

Meiwes, Relinde 2008: Katholische Frauenkongregationen und die Krankenpflege im 19. Jahrhundert. L'Homme: Europäische Zeitschrift für Feministische Geschichtswissenschaft 19:1, 39-60.

Mintz, Sidney W. \& Eric R. Wolf 1950: An Analysis of Ritual Co-Parenthood (Compadrazgo). Southwestern Journal of Anthropology 6:4, 341-368.

Ryan, Louise 2011: Transnational Relations: Family Migration among Recent Polish Migrants in London. International Migration 49:2, 80-103.

Wolf, Angelika 2010: Orphans' Ties - Belonging and Relatedness in Child-Headed Households in Malawi. In: Hansjörg Dilger \& Ute Luig (eds.), Morality, Hope and Grief: Anthropologies of Aids in Africa. New York \& Oxford: Berghahn, pp. 292-311.

Gertrud Hüwelmeier is an anthropologist and a senior research fellow at Humboldt University, Berlin. She is the Director of the research project The Global Bazaar: Markets as Places of Economic and Social Inclusion, funded by the German Research Foundation. Her publications include articles on transnationalism, religion, gender, postsocialism, cosmopolitanism and global Pentecostal networks. Her most recent book, edited with Kristine Krause (2010), is Traveling Spirits - Migrants, Markets and Mobilities (London: Routledge).

(ghuewelmeier@yahoo.de) 


\title{
GROUNDING THE FAMILY Locality and its Discontents in Popular Genealogy
}

\author{
Elisabeth Timm
}

\begin{abstract}
This paper discusses the grounding of the family in popular genealogy today. It applies a historical and comparative approach to the use of parish registers in three empirical cases from Austria. This use consists in a continued process of rooting the family locally, while simultaneously delocalizing it through the digital connection of data kept separate by the Catholic Church for many centuries. Grounding the family is thus a complex articulation of the modern discourse of settledness, closely bound up with a popular historical culture able to access archival sources directly for the first time in history. The paper questions the category of "imagined families", which may marginalize this popular practice of producing kinship and perpetuate the essentialist notion of otherwise "authentic" (e.g. juridical, social, biological) families. ${ }^{1}$
\end{abstract}

Keywords: genealogy, family, migration, archives, Austria

Hello and good day to you, as a new member of this list I'd like to introduce myself briefly, my name is Georg Jochum, 64 years old and I live in Barsinghausen which is near Hanover. (...) My forebears came from Graben/ Karlsruhe and seem to be spread across all of northern Europe. That's why I joined this list, because bearers of my name also ended up in Vienna. But it seems that the JOCHUM family in Vienna has died out. (...) Maybe one of the list members has the family name JOCHUM in their files, I would be grateful if you could get in touch. Greetings from the far north. Georg (Jochum)²

Posted on an email discussion list in 2011, this email is a dense and complex articulation of the relationship between family and locality in popular genealogy today: the genealogist introduces his family, defined in patrilineal and historical terms, through its surname; he locates it in one (and only one) place, but also finds himself confronted with migration, leading him to begin his search at many locations. That is, he is aware of the history of the production and processing of genealogical data recorded by the state, communes, and churches over the last several centuries. A virtual place that enables him to access this data is the "austria" mailing list, a German-language forum open to everyone researching "in all the southern areas that belonged to the Habsburg monarchy up to 1918". Mailing lists like this one are interfaces between the localization of the family and its de-localization. The names of the lists correspond to the 
political, geographical, and ethnicized contours of Old Europe, with an "austria list", a "bavaria", "sudeten", "gottschee", "slovakia", "westphalia”, "prussia", "switzerland”, "poland", and other lists. Yet at the same time, the users of the lists disclaim this historical world, because their databases generate a digital kinship that is no longer represented within this national, ethnic, and geographical order.

Genealogical sources have always arisen in relation to place. As Foucault (2007: 555-583) has shown, from the seventeenth century onward statistics emerged as a new form of government and "population" became an object of knowledge for the state, but long before that - starting with the Council of Trent in the mid-sixteenth century the Roman Catholic Church had begun to keep parish registers: records of births, marriages, and deaths that registered their objects in relation to place. Popular genealogy today uses this historical data and operates with this knowledge (in this case, the "distribution" of the "forebears", or the idea that if I have ancestors in Vienna, I must network within the "austria" list that specializes in the southern Habsburg monarchy). For this reason, I argue here, popular genealogy grounds the family - both founds it and ties it to locality - not in Austria but with Austria. Yet at the very same time, it also delocalizes the family (the family name will be found in the "files" of some list member), reassembling it in new emplacements that are generated not by the technologies of rule but by the individual ("my forebears came from Graben/Karlsruhe"). At first sight, the label “imagined families" thus seems to capture neatly the notion of family that is at work in popular genealogy. However, on closer examination it becomes clear that such a definition would establish a problematic distinction - problematic because it asserts that the state of being "imagined" is limited only to particular families, and because it would have only essentializing responses to the question of what a non- "imagined" family might be.

In this paper, I use the example of the production and utilization of parish registers in Austrian popular genealogy to examine how family and locality are at once connected and unbound. I show that the place where a family "comes from" or "originates" (thus the semantics in this field) always combines a dynamics of ontology with one of atopia. Every genealogical practice gives rise to both moves: the ontologizing deployment of locality as the first foundation of the family being researched, and the atopic pursuit of the family beyond the locality-bound sources. I conclude that a distinction between "imagined" and "actual" does not account for the family of popular genealogy. This becomes particularly apparent in the interplay of location and dislocation that is continually produced by the epistemic medium of the parish register.

\section{Research on Popular Genealogy: Findings and Perspectives}

In the classical phase of anthropology, genealogies were not only an object of study but also an instrument of analysis. After the crisis in the anthropology of kinship, this object attracted new interest and new perspectives, from both "new kinship studies” (e.g., Bouquet 1996; Franklin \& McKinnon 2001) and its critics (for German-language ethnology, see Schnegg et al. 2010). ${ }^{3}$ In contrast, European ethnology and folklore studies paid almost no attention to popular genealogy until very recently (with some exceptions, e.g., Byron 1998). The scattered early studies on popular genealogy in Euro-American ethnology's societies of origin were carried out by historians and sociologists (e.g., Burguière 1997; Hareven 1978) or by French or Anglo-American anthropologists (e.g., Ayoub 1966; Sagnes 1995; Segalen \& Michelat 1990). This work indicates that local references and their political frames, such as the nation state, are utilized by popular genealogy activists in differing ways. They may be accentuated and selected, which is usually read by researchers as a way of producing and safeguarding "identity" (Angelidou 2001: 11; Caron 2002; Segalen \& Michelat 1990: 208). For this approach, it is a short step - probably too short - from popular genealogy to "identity", be- 
cause the genealogical format is methodologically posited as a cultural form with an established, inherent effect. This contrasts with approaches that do not formulate "identity" as a given, defined and defining magnitude in their investigations of popular historical culture (Byron 1998; Edwards 1998: esp. 148, 155, 157f., 161). In his study of the genealogical emplacement of the Irish diaspora in the United States, Byron (1998: 27) reflects upon "ethnic identity" in multiple ways: firstly as an "empty vessel" both produced and invoked in the social context, which needs to be interrogated using a critical theory of the subject; secondly, as regards the evaluation of ethnographically collected data, he asks whether it is in fact feasible to infer a collective self-location ("ethnic identity") from the empirical material (ibid.: 33f.); and thirdly, he questions the empirical findings in methodological terms: "That we were a research team from Ireland interested in their Irish connections and their sense of Irishness undoubtedly influenced what our informants told us" (ibid.: 34; for a similar methodological reflection, see Edwards 1998: 155). Malkki (1992: 25) pinpoints the problem of the methodological coupling of "genealogy" and "identity" by noting that it rests upon "deeply territorializing concepts of identity".

The present paper picks up and advances this latter perspective, which takes the equation of genealogy and locality as its object of study. I argue that the territorialization of kinship knowledge is not, and has not been, a predetermined feature of genealogy or of genealogical research. Rather, the identification of "being kin" with "being there" has had to be constantly produced and secured afresh - in fact, this is a case of the production of settledness. ${ }^{4}$ It has been studied in some detail within the history of ideas and political thought, as the socially conservative ideological pairing of family and locality among nineteenth-century political theorists of society like Wilhelm Heinrich Riehl (1855) and Frédéric Le Play (1855). These two scholars grounded the family in blood, in the patriarchal order, with nature, and via property ownership. Jacques Donzelot's (1979) discourse analysis has shown how the "policing of families", and especially "familializing the popular strata", in the second half of the nineteenth century was spatially fixed and literally emplaced through its crucial grounding in architecture. ${ }^{5}$ Pierre Bourdieu (2005) traced in detail the resulting Fordist social order that finally supplied the lower social strata with homes of their own as well, localizing them in bourgeois respectability but also putting them under economic pressure and chaining them to their "house". Research on the Parisian bourgeoisie of the present day indicates the extent to which an assumed genealogical and spatial locality forms part of the symbolic capital of these families. ${ }^{6}$ Since a genealogy of settledness has not yet been written, ${ }^{7}$ these case studies must suffice to hint at the extraordinarily momentous establishment of settledness for, and by means of, the modern Euro-American family in the modern era.

Presenting three case studies from a micro-perspective, in the following I will show how genealogical practices can articulate the family again and again as the sum of locations and dislocations.

\section{A Genealogy of Grounding Family in and with the Parish Registers}

My argument in all three cases proceeds from written, materialized sources of popular genealogy: parish registers, in Germany called Kirchenbücher and in Austria Matriken. It would be easy enough to classify this written record in one of two ways. Either, as Goody (2000) argues, the parish registers are instruments with which the Catholic Church pursued its economic interests (i.e., safeguarding legacies) by keeping track of kinship relations, enforced the canonical prohibitions on marriage, and by these means contributed to the replacement of kin-based, extended, and spatially dispersed social formations by the small, homebased "European family". Or the parish registers' function may be interpreted analogously with Foucault's (2007) thesis of the emergence of state statistics from the sixteenth century on as part of a new technology of power that produced "population": as a means of government which the Catho- 
lic Church used to flank its pastoral techniques and tie them to territory, and the causes and effects of which cannot be explained by economic interests alone.

However, rather than trying to fit the parish registers into one of these hypotheses, I prefer to discuss the different ways they have been handled by genealogy. I think of the empirical sources not as representations of hidden forces of history (such as economics or power), but as "actants" in the sense of Latour's (1996) actor-network theory - in other words, as virtual or material participants that develop their own logic and their own dynamic within the genealogical procedure. The three cases of genealogical practice I have selected exemplify the fact that "settledness" is not a given, and that "migration" is not its other. Instead, it will become clear that mobility and immobility can only be adequately understood as relational complements. The three examples are taken from Austria (I will come back to the problems of this localizing statement); they are small segments from my more extensive study on the cultural anthropology of popular genealogy. I arrange the cases not chronologically, but in the order that they made their appearance in my research. By choosing this arrangement, I am also suggesting a potential relationship between ethnographical and historiographical approaches to popular genealogy: is it possible to identify historical links or formal peculiarities without organizing these as a linear array, but also without essentializing them by detaching them from history?

I firstly show how Catholic priests in Bavaria and Styria between the wars invented a Volksgenealogie, "folk genealogy" - and, in their study of the parish registers, were taken aback by migration. In politically agitated times, they had hoped to extract a sense of stability from these monolocally organized genealogies, yet such stability was precisely what the sources refused to supply.

I then go back several centuries, to the period of the Reformation and the beginning of the parish registers. Later used by priests as their sources, the registers began life as sources produced by priests.
Genealogy here is a way of fixing the kinship knowledge of the Catholic Church's canon law, a technology for dealing with migration. My study of the sources demonstrates that the parish registers, as the key materials of genealogical research, originated in part from a confrontation with migration.

Finally, I turn to popular genealogy today, and specifically the ways that its networking, data, and knowledge formats ground and, simultaneously, digitally dislocate the family. In these genealogical practices, emplacing the family is both the objective and the means of the research - for without knowledge of the church, state, and communal record-keeping that divided people up by place and by rule, it is impossible to pick up traces in the archives and find the desired documents. Where migration interrupted the processing of kinship knowledge into the parish registers, today's popular genealogy is collectively working to close the gaps, as becomes particularly clear in the case of the project to create a digital "marriage index".

\section{Producing and Using Church Registers: Three Examples}

\section{Styria, 1919: Priests Grounding the Family}

In the mid-nineteenth century, the history of the countryside had already come to the attention of scholars, Heimatpfleger or "nurturers of local life", and of social policy-makers in the context of urbanization and industrialization. As the weapon of choice against the "flight from the land" (the term itself was a political battle cry), ideas of agrarian romanticism arose that also contributed to the formation and expansion of folklorist interests in this period. Agrarian romanticism's interest in the rural space and its history, gathering pace since the mid-century, had also embraced genealogies. ${ }^{8}$ In many European countries in the late nineteenth century, priests and ministers began isolated genealogical studies in towns and villages, taking their own parish as their object and starting point. Between the First and Second World War such projects, especially in Styria and in Bavaria, were drawn together under the head- 
ing of Volksgenealogie or "folk genealogy". The political basis of this movement's argument was partly the notion of Heimatschutz, "protecting the homeland”. Its advocates' energetic agitation was often largely dismissed by the local population, as Judson (2006) has shown for the case of nationalist language policy in Styria. This may be one reason why ever new arguments had to be sought, as here in the case of "folk genealogy", where a family imagined in deeply historical terms was set up in opposition to the "flight from the land".

When the Styrian priest and theologian Konrad Brandner started his genealogical research in 1919, he turned first to the registers of the parish of Haus, the oldest volume of which is a register of baptisms begun in $1586 .{ }^{9}$ In making this decision, he was going back to the earliest accessible point not only historically (even now, no older parish registers have been found to survive in Styria; see the compilation in Ruhri 1997: 123-138), but also biographically: Brandner had started his pastoral service in August 1905 to August 1907 as a chaplain at the Ennstal parish of Haus. He had no overview of the state of the sources, but judged the parish registers to be reliable evidence of a longstanding affinity between family and settledness. His key objective was to influence the rural population: "Genealogy now shows them [the inhabitants of Styria] in a documentary manner how long and where their family has been settled (...). This awareness will without doubt increase love for the homeland and spin threads between the past and the present" (Brandner 1920: 9)..$^{10}$

In his vision of popular genealogy as a brake on migration, Brandner assumed that an agrarian economy correlates with geographical immobility (Brandner 1926). However, the "folk genealogists" did not succeed in proving this claim. The correspondence of the priests carrying out genealogical research hints at a perplexity arising from the sources: many of their research reports and reflections on the innovative project of a folk genealogy discuss migration, and there are also specific assessments such as the following: "This study may, at least, indicate that even in such in- hospitable regions, the 'internal migration of the peoples' is far from insignificant” (Felber 1927b: 10; see also Felber 1927a). But the genealogists did not allow such findings to shake their postulate of sedentarism, and the assertion that families from the villages had been immobile for many centuries remained intact. Interested in people's Bodenständigkeit, their autochthony or "rootedness in the soil", Brandner concentrated on the cases that supported this fantasy (Brandner 1926). He noted the predominant finding that most of the families showed no such Bodenständigkeit:

When I considered this result, I saw that among them there are many genealogical tables that cover only two or three generations. (...) They thus stand, so to speak, as fragments of a lineage in folk genealogy; in many cases these will only have been fragments split off from larger lineages in other locations. (Brandner 1926: col. 227)

Here Brandner identifies and isolates the empirical findings that counter the thesis of Bodenständigkeit - he qualifies the quantitatively prevailing cases as a "fragment", something "split off". Methodologically, he thus makes settledness an Archimedean point that permits him to register migration while leaving Bodenständigkeit untouched. At times Brandner gave very explicit form to this profile of his genealogies, marked both by a new collapse of boundaries and by new demarcations: "Of course, only persons born in Styria could be considered for the genealogy, in other words also many people who live outside Styria; however, on the other hand, many persons living in Styria would not be included in the genealogy because they were not born there" (ibid.: col. 228).

Even the völkisch protagonists of folk genealogy did initially take note of the migration that appeared in the sources. For example, having completely transferred the information in the registers from 1650 to the present for his 650-soul parish to a card index and arranged it into descendancy lists, Josef Demleitner - a Bavarian priest who later achieved fame through his guide to genea- 
logical research or Sippenkunde ("clan lore") in the context of the Nuremberg Laws (Demleitner \& Roth 1935, 1936) - wrote the following in a letter to his Styrian colleague Brandner in January 1926:

When I looked through various parish registers in the area this year for a local-history study on the Thirty Years' War, I found that, particularly in the 1650-1680 period, a tremendous number of strangers settled in the area through marriage. At least the tenth part of all weddings are to foreigners. At any rate, as folk genealogy advances, some attention must be paid to the question of population exchange.

The folk genealogists' surprise at migration articulates the grounding of the family with great precision: they had worked their way through the records of the Catholic Church in the sure conviction of finding settledness there. The settled ideal that the priests intended to find in the parish registers reflects the discourse of a sedentary Europe. The correspondence demonstrates how the folk genealogists, searching for Heimat and aiming to produce the region in a combination of temporal constancy and spatial immobility, came up against a mobile history. At first, the priests reacted to this confrontation with surprise and curiosity; even an ideologue like Josef Demleitner did not immediately resort to denying this rupture of the nationalist ideal of centuries-old, secluded rural localities, home to enclosed families and clans. There is an element of tragicomedy in the way that these pastors, facing the depopulation of the villages, sat down at the sources to build bonds to the locality in support of settledness and love of Heimat, only to be confronted with and disappointed by the internal European migration of the past three centuries.

In the correspondence of folk genealogists of the early interwar years, the researchers still responded to the registers' indications of migration using the tools of debate and argumentation. Just a few years later, that space no longer existed.
The compulsory genealogy that the Nazi state imposed through the Nuremberg Laws of 1935 (Ehrenreich 2007; Pegelow 2006) depended on forgetting the knowledge of migration that folk genealogy had addressed. When Georg Grüll, "Gausachbearbeiter für Sippenkunde im Gau Oberdonau" ("Regional Officer for Clan Lore in the Upper Danube Region"), organized the cardindexing of the parish registers in the early 1940s, settledness had already become a methodological essential. In point 8 of his 1941 "Instructions for card-indexing the Linz parish registers", he required the indexing staff to fill out the marriage cards as follows:

The place of origin of A and B [i.e. the bridal couple] need only be included if it differs from the place of residence of the parents. (...) In a rooted [bodenständig] population, this field will as a rule remain empty, because the bridegroom's and the bride's place of origin will accord with that of their parents. ${ }^{11}$

In the Nazi period, settledness appears as the ideal of an identity between descendancy and alliance. ${ }^{12}$ Nazi genealogy no longer expects to find any disparity between the two, and logically enough the regional genealogical officer signals an "empty field" in this segment of the data record. The empty space is there to prove that no rupture has occurred: that is the völkisch grounding of the family.

This conclusion is not new; it has already been set out in analyses of the ideology of "blood and soil". However, the present micro-perspective on the genealogical utilization of historical sources shows how close the nationalist "folk genealogists" came to quite different evidence. Consulting the parish registers, they were using sources for the grounding of the family that had been created in the sixteenth century to localize kinship knowledge, but which nevertheless passed on manifold evidence of the disengagement of family and locality, as I shall now show. 


\section{Styria, 1563: Priests Producing Sources}

The sources used by the folk genealogists were almost exclusively parish registers, and even today these books are key sources for popular genealogy. The history of such documents, and of the knowledge practices from which they emerged, is closely bound up with far-reaching political, religious, and social conflicts in Europe over the past five centuries. In the sixteenth century, parish registers were developed by technologies of power that could no longer make use of older forms of personal documentation - the medieval lists of townsmen or nobility, for example - because of their estates-based profile. Whereas older techniques for documenting populations were socially segregated and specific (each listing, for example, only townspeople or only nobles), parish registers were socially undefined from the very start.

The existence of parish registers in the Catholic Church goes back to the Council of Trent, 1545-1563 (for the case of Styria, see Ruhri 1997: 109-111; see also the following points). The Council's decree Tametsi of 11 November 1563 required all parishes to keep registers of baptisms and marriages. With this, the Catholic Church's documentation of the population was founded upon the documentation of the population-as-Catholic: the objects of the parish register were initially neither birth nor death but two Catholic sacraments, baptism and marriage. Parish priests were charged with entering the data and preserving the registers, in the shape of books or loose-leaf collections. Entries included the names of the bridal couple and the witnesses along with the day and place of the wedding, or for baptisms the names of the infant and its godparents.

The decree Tametsi is the founding document of the Tridentine marriage. It was the Catholic Church's reaction to religious, political, and social upheavals in the sixteenth century that sprang from many different sources: Reformation and Counter-Reformation, increased mobility, new family structures and lifestyles resulting from changes in urban life, and an altered form of statehood that no longer rested on the person and family of the monarch. The new registers also responded to the everyday conflicts arising from the practice of "clandestine marriage" in the sense of marriage without a specific ecclesiastical form - the marriage format that had previously dominated in quantitative terms, except among the nobility and burghers, most of whose marriages were recorded by notaries and therefore, as in Roman law, functioned contractually, as agreements, rather than spiritually, as sacraments (Zarri 2001: 344f.). The Council of Trent decree turned the private matter of marriage, an undertaking between two individuals, into a public, formalized, written, clericalized, and sacralized act (ibid.: 361 ), and made priests the crucial figures in what may be described as a "disciplining" of the family (ibid.: 364f.).

Zarri (ibid.: 362; see also the following points) additionally interprets the parish registers as a means of creating a legally unequivocal definition of the domestic community in the context of growing conflicts around children born out of wedlock. But most relevant to the question addressed here, the localization of family, is the fact that the parish registers were first and foremost a technology for disciplining lower-status and mobile population groups. Increasing mobility threatened to hollow out the epistemological foundations for enforcing Catholic canon law, oral communication; the Church responded by switching to the written word. However, the parish registers did not completely replace oral tradition, for the regulations surrounding the Tridentine marriage also required the reading of banns, in other words the public announcement of a marriage among the congregation before the wedding. This targeted and prescribed scanning of unwritten kinship knowledge at the occasion of the wedding was intended to supply information about any impediments to marriage, namely family relationships that precluded marriage under canon law. The Church was not willing or able to rely upon the kinship knowledge it had itself recorded in written form. Publishing the banns was the technology that riveted together local kinship knowledge and 
practices - "habitual kinship" - with the "official kinship" (Lanzinger \& Saurer 2007) of the parish registers. ${ }^{13}$

The development of record-keeping was continued with Paul V's Rituale Romanum of 17 June 1614 , which prescribed the compilation of registers of confirmations and deaths (or rather funerals); these registers were also to include information on the family of the person involved. On 20 February 1784, the Habsburg Emperor Joseph II issued an edict making the keeping of parish registers a state duty, although he devolved this to the churches and state-recognized religious communities (Ruhri 1997: 108, 119). One consequence of this was the standardization of entries through the use of pre-printed tabular forms (Becker 1989). But whereas the German Empire established state civil registers in 1874, in Austria the parish registers remained the only documentation of this kind until 1938. State documentation has only existed in Austria since 1 August 1938 (the introduction of civil marriage) and 1 January 1939 (the establishment of civil registry offices).

In various historical contexts throughout Europe, long before the creation of a system of state civil registration, conflicts frequently arose around the right of access to the parish registers, as did calls for them to be taken into state hands. The Council of Trent had authorized priests to administer the parish registers, and they held on to that responsibility. The keeping of registers did not begin immediately in all parishes; there is evidence in the case of Styria, for example, that this sometimes took several decades and rebukes from the bishop. However, when a parish register was set up, priests quickly took up their role as guardians of the archive. Once the volumes came into existence, what Latour calls their "programme of action" began to unfold: mediating between locality and movement, and between connection and separation. Within that field of tension the priests acted as archontes, as the high officials and custodians of the archives, who constantly developed new ways to combine the collection and sealing of knowledge in the books with the publication of knowledge and opening of the books. ${ }^{14}$

The registers always physically remained within the parishes, and this sedentary aspect both expresses and explains the fact that it was nearly the middle of the twentieth century before kinship knowledge could be produced from the parish registers that was not separated out and tied to a particular location. When Catholic priests in the interwar period began, as I have described, to use these volumes as historical sources for their "folk genealogy", that move displays typical elements of an innovative utilization, and is not a distinctive feature of the history of Church documentation. In her genealogical study of files, legal historian Cornelia Vismann (2008) shows that well into the sixteenth century, the processing of the state and municipal administrations' files consisted in either using them within the chancery or storing them - they were not yet deployed as historical sources, and "it took a long time for the practice of referring to old files to assert itself" (ibid.: 99). The Catholic Church in Austria had not even centralized the storage of parish registers, which is why the folk genealogists had to work on the registers of their own specific parishes. Even the diocesan archives that have now taken on the parish registers do not hold them as property, but preserve them in trust for the parishes (thus Ruhri 1997: 122 , on the diocesan archives in Graz-Seckau). In fact, even today a clear distinction between chancery and archive has not yet been established in the parishes.

The most recent utilization of the parish registers, present-day popular genealogy, leapfrogs that distinction by digitizing the data to create an open archive. In its indexes and databases, simple search runs can close many of the gaps in kin connections that were opened by the local storage of the parish registers and by their localization of kinship in many different ways. Although this present-day use of the parish registers initially also arises from a desire to identify a particular family and to ground it historically in a single location, there are two further products of popular 
genealogy's indices and mailing lists: on the one hand new relays that for the first time delocalize kinship knowledge, and on the other a popular historical culture with direct access to archival material.

\section{The Net, 2007: The Marriage Index}

Present-day genealogical research - which must rely on the parish registers if it is to reach back over centuries - always starts, like the email cited at the opening of this article, with a place: "My family comes from ...". However, later this spontaneous logic of place is often frustrated. The researcher comes up against too many "blanks" - tote Punkte, "dead points", in the German genealogical jargon - so that church records from other parishes have to be consulted in order to trace further connections and set up new relays. The converse of "the blanks" is "serendipity" ( $\mathrm{Zu}$ fallsfund), the chance discovery of an individual in the register of a parish where he or she was not resident (for example in a marriage or godparenthood entry). Using mailing lists and the Internet, popular genealogy today brings the "blanks" into contact with the "serendipities", so that kin connections can be traced beyond the records that are localized by parish.

To be sure, these techniques are not the first attempts to overcome the locality of kinship knowledge. Popular genealogy worldwide has focused particularly on the Mormons' efforts to microfilm and centralize parish registers, which began as early as the 1930s. ${ }^{15}$ The Salt Lake City vault where these microfiches are stored is regarded in popular genealogy as a "mythic place" (Sagnes 1995), partly because of its association with the practice of baptism for the dead, but, among those active in genealogical circles, also as a "disputed paradise" (Richau 2007). It is a place that for many centuries did not exist because the church registers, scattered by parish, never documented every connection. The Mormon archive in Utah is a kind of super-locale for the grounding of the family. Yet it dates from an era that was able to bring together the parish registers materially, as microfilm, but not informationally. That would be achieved only by today's newest generation of popular genealogy, which switched from the analogue mode of centralizing material sources into the digital mode of data without locality. I will now discuss how popular genealogy is collectively producing this unseparated kinship knowledge, using the example of a "marriage index".

Several years ago, I interviewed Herr Noggler. ${ }^{16}$ $\mathrm{He}$ is a well-known activist of popular genealogy in Austria, and is one of those who organize and network activities (in associations, mailing lists, and web portals) and advance the field through methodological innovation. His work is not limited to research on his "family"; rather, he develops forms and formats of digitizing the historical source material that enable linkages far beyond what was available to him when he first began to research his "family history". It is a notable feature of this type of popular genealogist that his innovations are developed inductively, out of his confrontation with problems of researching "my family" in the parish registers:

It's a regional peculiarity that for baptisms the mother's maiden name isn't included, and that makes it difficult, and for marriages, if the parents' names are not included, then it really gets problematic. If it only says that bridegroom and bride married, then that's a problem, but I have - if you want some idea of numbers - I have found 560 or 570 of my paternal line, mainly - not only - in Lower Austria, and more than 200 from my grandfather's line in the Bohemian Forest or round about 200, and for those of my grandmother it's now about 140 . But that's also because registers are missing there, we've now even begun, with a few colleagues, to completely transcribe the registers of Liebental - that's the main relevant parish in Austrian Silesia (...) and to draw up tables of names (...). You wouldn't believe what there is lying around in the archives, tons of material, mostly not indexed (...). 
"For marriages", "if it only says that bridegroom and bride married", then the genealogist is confronted with a "blank", a "dead point": alongside the names of the bridal couple, he finds no reference to their place of residence or birth, and thus cannot go to the parish archives of that locality to research their family background. In a case like this, his search for his genealogy comes to a stop. But Herr Noggler thinks beyond the locality of kinship that the parish registers present him with: his comment "mostly not indexed" implies that he could find many more connections if the material were arranged in a different way, if it were switchable as data. Herr Noggler has put that insight into practice, playing an active part in the association "Familia Austria", which he also helped to found. ${ }^{17}$ Of the association's many and various activities - networking genealogical activists and creating cooperative, collaborative structures to digitize data from historical sources (these might be written sources in archives, or gravestones carrying personal data) - the marriage index ${ }^{18}$ is of particular relevance for the grounding of the family in popular genealogy. The index's presentation clearly shows the inductive procedure applied when networking the data. Popular genealogy may start out from research on "my family", but that search soon generates very different dynamics:

\section{Marriage index}

Almost every genealogist and family researcher has been there: you find the baptism of a forebear some time in the sixteenth, seventeenth, or eighteenth century, but the wedding of the baby's parents and the parents' birth or baptism entries are nowhere to be found, even though you know their names. First you search the registers of the surrounding parishes (...). But then in most cases there is nothing else you can do! You will now only be able to make progress if, by a lucky chance, you discover the parents' marriage somewhere after all. Some colleagues then invest years of work in complicated name analyses, bombard the parishes of whole regions with enquiries, and put together extensive studies of migration in the period concerned. But most of these cases unfortunately remain unresolved. This is where our MARRIAGE INDEX initiative comes in.

Working together with, if possible, all the parishes in former Austria Hungary, we are drawing up name indexes of the marriage registers, or collecting indexes that have already been made, and making this data accessible in a shared searchable database.

(...)

Our aim is to make it possible to track down ancestors who have moved across long distances (and whose origin is not named at their place of destination).

In the genealogical project "marriage index", both the family's settledness and its de-localization materialize. Today, the first step is still to assume the emplacement of familial reproduction - which is why the genealogists work concentrically outwards from the baptismal location of the "forebear". But because most genealogists in these circles have now acquired very sophisticated historical knowledge (in the history of administration, social history and the history of rule) as well as skill in the use and critique of sources, particularly through the case-specific exchanges in mailing lists, they now wish to address the problem in a more thorough-going way. The marriage index realizes a delocalized kinship on the basis of the very parish registers that were created to localize the family. Where the historical sources are silent because they divide up kinship knowledge by place, the digital mode makes them speak again. Within a few clicks searching the index, a "blank" or "dead point" can become a potent relay. It is true that this move is once again linked to the restrictive grounding of a - "my" - family: as Herr Noggler put it in the interview, "my mother is descended from Sudeten Germans". But this topographical ontology is not a logical consequence of the data researched or the atopic linkages that Herr Noggler himself helped bring into being. Rather, it is a 
practical consequence of the suspicion of ontology that fuels the research.

\section{Conclusion: Grounding the Family and Losing Locality}

These three cases of the genealogical handling of parish registers indicate the complexity of the dynamics associated with the grounding of the family. In the history of genealogy, the parish registers are an extremely dynamic epistemic medium, on the one hand producing settledness and migration as complements while, on the other, creating connections between them.

Rather than grounding its family in Austria, popular genealogy grounds it with Austria - locality functions both as the ontological grounds of the family and as the medium of research. But in this encounter with the sources, objectives and outcomes ultimately emerge that the researchers had not intended: the genealogists develop a pleasure in tracking down information, in source criticism, in historical and critical evaluation of their data, in their growing knowledge of European history. In parallel to its location and dislocation of the family, popular genealogy also brings forth a historical culture. This vernacular historiography emerges not via the mediating authorities of public cultural and educational efforts, but in direct contact with the archives. This is why Tyler (2005) emphasizes the emancipatory thrust of popular genealogy today, while Hackstaff (2009: 178) refers to a "democratization of genealogy". Direct, unmediated access to the sources is a specific enjoyment that arises precisely from the problems encountered in research. It rests not on a positivist reading of the sources, but on an open process of interrogating one's own research results, and on the knowledge that there are also research situations (for example in the case of homonymy) where it is not possible to move forward. In her ethnography of US genealogical associations, Hackstaff (ibid.) has described this attitude as "analytic realism". It is, though, striking that this criminological pleasure in working on sources does not supersede the grounding of the family but, on the contrary, is inextricably connected with it. It is only the imagining of a monolocally situated family and the attempt to verify this which leads to the navigation through the archives - a navigation by means of which popular genealogy simultaneously reconstructs historical migrations and digitally erases them.

The question now arises whether this grounding of the family is specific to the Austrian situation. Because few case studies on popular genealogy have so far been carried out, this cannot be answered with certainty; but historical emplacement is always involved in popular genealogy. It is worth noting that many studies on the United States describe popular genealogy as working with a combination of historical sources and genetic testing (Hackstaff 2009; Nash 2004; Nelson 2008). This may be partly due to the particular questions such studies pose - certainly, Tucker's (2009) ethnography, focusing primarily on the relationship between public and private archives, does not confirm the hypothesis that genetic kinship is central to US popular genealogy. There do seem to be some features specific to popular genealogy referencing Scotland and Ireland and to black genealogies: the political and economic momentum of the heritage industry and a sophisticated "roots tourism” sector (Basu 2005; Basu 2006; Gilroy 1997; Legrand 2006; Schramm 2008) - formations that have not been recorded for genealogy relating to other countries, at least in Europe. Critically upturning the question of the national specificity of popular genealogies today, one might conclude that the question itself does not so much address cultural differences as pursue a "methodological nationalism" (Wimmer \& Glick Schiller 2002). Within which popular genealogy should we classify, for example, an activist living in Australia who is researching his ancestors in Europe by means of the "austria", "slovakia", and "switzerland" mailing lists, archive visits, and databases? Just as popular genealogy is unsettled by historical migration as it searches for unequivocal localizations of its family, the digital mode of current popular genealogy's networking and information exchange is 
antagonistic to an anthropological form of questioning that focuses on the national specificity of popular genealogies.

I also doubt that "imagined" adequately describes the specific kinship whose grounds popular genealogy both seeks and disrupts in the course of its encounter with the parish registers and other sources in its databases. The ligature between family and place is not an "idea" or "mental image" external or subordinate to an otherwise authentic (e.g. social, juridical, genetic) kinship. Rather, grounding the family causes an ontological unrest that is what produces the kinship of popular genealogy in the first place. Therefore, my comparative discussion of the genealogical production and utilization of the parish registers since the sixteenth century stresses that locating the family is always associated with dislocating the family. Unlike an intellectual or political history of settledness, the perspective of cultural anthropology can face up to the finding that knowledge about the discontents of locality is not simply the result of academic research, but itself part of the field it studies.

\section{Notes}

1 The article was translated by Kate Sturge. I thank her for the thorough discussion concerning translations from historical sources. Also, I would like to thank the four anonymous reviewers for their critique and valuable suggestions regarding the first version of this article.

2 Austria-L, 23 September 2011 (names anonymized), http://list.genealogy.net/mm/listinfo/austria-l (accessed March 28, 2012). Here and throughout, translations from German are by Kate Sturge.

3 These new perspectives on genealogy must be placed in the context of increasing anthropological research on family and kinship (for selected European states, see the extensive historical and contemporary, quantitative and qualitative comparative studies by Beck et al. 2007; Grandits 2010; Heady \& Kohli 2010; Heady \& Schweitzer 2010; Knecht, Klotz \& Beck 2012; Segalen 2012).

4 The "transnationality" of kinship is not a recent phenomenon. As has been sufficiently demonstrated, kinship was never something immovable, either in the city or in the village or provinces: labour and economic forms (e.g., transhumant shepherds), markets and commerce, natural disasters, pilgrimages and wars, the science and technology of ecclesiastical and secular powers (such as visitations, tax collection, population censuses), and not least emotional yearnings have always given rise to mobility, including in pre- and early modern Europe. Although there were certainly variations, with different regions experiencing more or less mobility, it is clear that the narrow horizons and immobility of the village were inventions of the nineteenth century - carefully crafted ideals that seemed to promise some contemporaries an element of stability in the maelstrom of manufacturing's dizzying pace.

5 Social housing construction in the nineteenth century calculated the space required very precisely, the objective being "to design a housing unit small enough that no 'outsider' would be able to live in it, yet large enough for the parents to have a space separate from their children, so that they might watch over them in their occupations without being observed in their own intimate play" (Donzelot 1979: 42). One figure of this discourse was the vagrant, who for "roughly ten years (1890-1900)" became the "universal of mental pathology" and a "special category" for the legal system (ibid.: 130).

6 "One does not search for one's roots; they are there, forming part of one" (Le Wita 1994: 120f.). Le Wita argues that the Parisian bourgeoisie's forms of housing and property - a town house, a country house - function not only as economic capital but also as symbolic capital, because they index the respectability of sedentary life in relation to the mobility of migration: "The existence of family seats places the bourgeois at the opposite pole from the migrant. His urban way of life is not made up of wrenching breaks or splits. He knows nothing of exploded kindred, the separation of the generations, weekends spent in the grey monotony of Paris or the suburbs with the children entrusted to their schools' outdoor centres" (ibid.: 35f.).

7 Deleuze and Guattari's nomadic utopia A Thousand Plateaus (1992) may be read as this kind of a genealogy of settledness - albeit one that is so obligated to the atopic that it cannot bring forth its nascently empirical approaches in the shape of recognizable "fields".

8 For example as peasant family histories or "family books", intended to help preserve ties to the agrarian lifeworld and working environment. Indications of this can be found in, for example, Wilhelm Heinrich Riehl's Land und Leute [Land and people] (1851), which recommends drawing up peasant family chronicles; in Die Familie [The family] (1855) Riehl calls for bourgeois family chronicles to be compiled.

9 Diocesan archives Graz-Seckau, Graz, Personalakten 
Priester, Dr. Konrad Brandner. Unless otherwise mentioned, this is the source of all information on Brandner in the following and all the documents cited.

10 In fact Konrad Brandner was aware of the existence of similar interests. He explicitly mentions, for example, the "efforts of folklorists", which he wishes to supplement through his project (Brandner 1920).

11 Upper Austrian Archives Linz, Arbeitsbund für österreichische Familienkunde [Working Group for Austrian Family Lore], box 9, Georg Grüll: "Arbeitsanleitung für die Verkartung der Linzer Kirchenbücher" [Instructions for card-indexing the Linz parish registers], November 1941.

12 In popular genealogy, this ideal resulted in a distinct genre, the Ortsfamilienbuch or village genealogy. These family registers are not simply one more component in the "grey literature" of this field; rather, they function as important interfaces between popular and scholarly genealogy or demography, because their use saves time compared with the extremely time-consuming research on the original parish registers. This certainly applies to the historical and demographic research carried out by the Cambridge Group for the History of Population and Social Structure (Knodel 1975, 1988; Knodel \& Shorter 1976). As can be seen in the example of Styrian folk genealogy, the compilers of these village genealogies (later also called Ortssippenbücher) were not so much collectors as editors of the material. For an example of source criticism on migration in an older form of the genre, the Familienbuch or "family book", see Lanzinger (2003).

13 However, it would be wrong to conclude that the introduction of the written form resulted in a straightforward implementation of canonical and legal provisions. The parish registers were compilations, open to interpretation, and all those involved (married couples and their relatives, representatives of state and church authorities) pursued flexible strategies and their own distinct interests when producing and deploying them (Lanzinger 2003, 2006, 2007).

14 In a late-eighteenth-century example, when the district authorities demanded access to baptismal registers in order to identify potential conscripts the pastors refused. They feared that making public the paternity of children born out of wedlock, recorded in the registers, would result in conflicts. In this case, the solution was to draw up a separate and confidential register, the liber arcanum, to document the baptisms of children born out of wedlock (Ruhri 1997: 117).

15 On genealogical research by the Mormons, see Mehr's overview (1992) and Richau's (2007) critical account from popular genealogy.
16 Interview with Herr Noggler, Vienna, May 5, 2007.

17 This association has no physical home. Some of its most active members have been working together for many years to digitize archival genealogical data without ever having met in person (interview with Herr Noggler, Vienna, May 5, 2007; interview with Frau Eschenbach, Vienna, March 16, 2009). As a result, the web portal does not indicate activity in "real life": it is itself the association. www.familia-austria. at (accessed February 10, 2012).

18 All the following quotations are taken from www. familia-austria.at/projekte/hzindex_projekt.php (accessed February 10, 2012).

\section{References}

Angelidou, A. 2001: "Qu'est-ce qui nous rassemble ici?” Mémoire généalogique, histoire locale et construction de l'identité dans un village contemporain. Regard sur la Bulgarie voisine. Strates 10, http://strates.revues.org/ document50.html?format=print. Accessed January 1, 2006.

Ayoub, M.R. 1966: The Family Reunion. Ethnology: An International Journal of Cultural and Social Anthropology $\mathrm{V}: 4,415-433$.

Basu, P. 2005: Macpherson Country: Genealogical Identities, Spatial Histories and the Scottish Diasporic Clanscape. Cultural Geographies 12:2, 123-150.

Basu, P. 2006: Highland Homecomings: Genealogy and Heritage Tourism in the Scottish Diaspora. London: Routledge.

Beck, S., N. Çil, S. Hess, M. Klotz \& M. Knecht (eds.) 2007: Verwandtschaft machen: Reproduktionstechnologien und Adoption in Deutschland und der Türkei. Berliner Blätter: Ethnographische und ethnologische Beiträge 42.

Becker, P. 1989: Leben, Lieben, Sterben: Die Analyse von Kirchenbüchern. St. Katharinen: Scripta Mercaturae.

Bouquet, M. 1996: Family Trees and their Affinities: The Visual Imperative of the Genealogical Diagram. The Journal of the Royal Anthropological Institute 2:1, 43-66.

Bourdieu, P. 2005: The House Market. In: The Social Structures of the Economy. Trans. C. Turner. Cambridge: Polity Press.

Brandner, K. 1920: Die Bevölkerung der Pfarre Weichselboden in Steiermark. Genealogisch dargestellt. Nebst einigen Gedanken über die Schaffung einer steirischen Volksgenealogie. Jahresbericht des Fürstbischöflichen Gymnasiums am Seckauer Diözesan-Knabenseminar Carolinum-Augustineum in Graz am Schlusse des Schuljahres 1919/20.

Brandner, K. 1926: Über Volksgenealogie. Familiengeschichtliche Blätter 24, 225-228, 293-296.

Burguière, A. 1997: La généalogie. In: P. Nora (ed.), Les Lieux de mémoire, Vol. III. Paris: Gallimard.

Byron, R. 1998: Ethnicity and Generation: On "Feeling 
Irish" in Contemporary America. Ethnologia Europaea 28:1, 27-36.

Caron, C.-I. 2002: La narration généalogique en Amérique du Nord francophone: Un moteur de la construction identitaire. Éthnologies comparées 4, 1-19, http://alor. univ-montp3.fr/cerce/r4/c.i.c.htm. Accessed March 27, 2012.

Deleuze, G. \& F. Guattari 1992: A Thousand Plateaus: Capitalism and Schizophrenia. Trans. B. Massumi. London: Continuum.

Demleitner, J. \& A. Roth 1935: Der Weg zur Volksgenealogie: Anleitung zur übersichtlichen Darstellung des sippenkundlichen Inhalts der Kirchenbücher in Familienbüchern. Munich: Oldenbourg.

Demleitner, J. \& A. Roth 1936: Der Weg zur Volksgenealogie: Anleitung zur übersichtlichen Darstellung des sippenkundlichen Inhalts der Kirchenbücher in Familienbüchern. 2nd, rev. ed. Munich: Oldenbourg.

Donzelot, J. 1979: The Policing of Families. With a foreword by Gilles Deleuze. Trans. R. Hurley. New York: Pantheon.

Edwards, J. 1998: The Need for a "Bit of History": Place and Past in English Identity. In: N. Lovell (ed.), Locality and Belonging. London: Routledge.

Ehrenreich, E. 2007: The Nazi Ancestral Proof: Genealogy, Racial Science, and the Final Solution. Bloomington: Indiana University Press.

Felber, F. 1927a: Fremde Zuwanderer in der Gebirgspfarre St. Johann am Tauern im 19. Jahrhundert. Mitteilungen über die steirische Volksgenealogie 6 (January 1927), 2-6.

Felber, F. 1927b: Fremde Zuwanderer in der Gebirgspfarre St. Johann am Tauern im 19. Jahrhundert. Mitteilungen über die steirische Volksgenealogie 7 (July 1927), 6-10.

Foucault, M. 2007: Security, Territory, Population: Lectures at the Collège de France 1977-1978. Trans. G. Burchell. Basingstoke: Palgrave Macmillan.

Franklin, S. \& S. McKinnon (eds.) 2001: Relative Values: Reconfiguring Kinship Studies. Durham, NC: Duke University Press.

Gilroy, P. 1997: Diaspora and the Detours of Identity. In: K. Woodward (ed.), Identity and Difference. London: Sage.

Goody, J. 2000: The European Family: An Historico-Anthropological Essay. Cambridge: Blackwell.

Grandits, H. (ed.) 2010: The Century of Welfare: Eight Countries. Vol. 1 of Family, Kinship and State in Contemporary Europe. Frankfurt/Main: Campus.

Hackstaff, K.B. 2009: Who Are We? Genealogists Negotiating Ethno-Racial Identities. Qualitative Sociology 32, 173-194.

Hareven, T. 1978: The Search for Generational Memory: Tribal Rites in Industrial Society. Daedalus 107:4, 137149.

Heady, P. \& M. Kohli (eds.) 2010: Perspectives on Theory and Policy. Vol. 3 of Family, Kinship and State in Contemporary Europe. Frankfurt/Main: Campus.

Heady, P. \& P. Schweitzer (eds.) 2010: The View from Below: Nineteen Localities. Vol. 2 of Family, Kinship and State in Contemporary Europe. Frankfurt/Main: Campus.

Judson, P. 2006: Guardians of the Nation: Activists on the Language Frontiers of Imperial Austria. Cambridge, MA: Harvard University Press.

Knecht, M., M. Klotz \& S. Beck (eds.). 2012: Reproductive Technologies as Global Form: Ethnographies of Knowledge, Practices, and Transnational Encounters. Frankfurt/Main: Campus.

Knodel, J.E. 1975: Ortssippenbücher als Quelle für die Historische Demographie. Geschichte und Gesellschaft 1, 288-324.

Knodel, J.E. 1988: Demographic Behavior in the Past: A Study of Fourteen German Village Populations in the Eighteenth and Nineteenth Centuries. Cambridge: Cambridge University Press.

Knodel, J.E. \& E. Shorter 1976: The Reliability of Family Reconstitution Data in German Village Genealogies (Ortssippenbücher). Annales de démographie historique, 115-154.

Lanzinger, M. 2003: Das gesicherte Erbe: Heirat in lokalen und familialen Kontexten. Innichen 1700-1900. Vienna: Böhlau.

Lanzinger, M. 2006: Heiratskontrakte - intermediär: Als Form der Vermittlung zwischen gesetztem Recht, sozialen Normen und individuellen Interessen. In: A. Klampfl (ed.), Normativität und soziale Praxis: Gesellschaftspolitische und historische Beiträge. Vienna: Turia \& Kant.

Lanzinger, M. 2007: Umkämpft, verhandelt und vermittelt. Verwandtenehen in der katholischen Dispenspraxis des 19. Jahrhunderts. In: M. Lanzinger \& E. Saurer (eds.), Politiken der Verwandtschaft: Beziehungsnetze, Geschlecht und Recht. Vienna: V\&R unipress.

Lanzinger, M. \& E. Saurer 2007: Politiken der Verwandtschaft: Einleitung. In: M. Lanzinger \& E. Saurer (eds.), Politiken der Verwandtschaft: Beziehungsnetze, Geschlecht und Recht. Vienna: V\&R unipress.

Latour, B. 1996: On Actor-Network Theory: A Few Clarifications. Soziale Welt 47:4, 369-382.

Legrand, C. 2006: Tourisme des racines et confrontations identitaires dans l'Irlande des migrations. Diasporas: Histoire et sociétés $8,162-171$.

Le Play, F. 1855: Les Ouvriers Européens: Études sur les travaux, la vie domestique et la condition morale des populations ouvrières de l'Europe, précédées d'un exposé de la méthode d'observation. Paris: Imp. Impériale.

Le Wita, B. 1994: French Bourgeois Culture. Trans. J.A. Underwood. Cambridge: Cambridge University Press.

Malkki, L. 1992: National Geographic: The Rooting of 
Peoples and the Territorialization of National Identity among Scholars and Refugees. Current Anthropology 7, 24-44.

Mehr, K. 1992: International Activities and Services of the Genealogical Society of Utah. Archivum 37, 148-157.

Nash, C. 2004: Genetic Kinship. Cultural Studies 18:1, $1-33$.

Nelson, A. 2008: Bio Science: Genetic Genealogy Testing and the Pursuit of African Ancestry. Social Studies of Science 38:5, 759-783.

Pegelow, T. 2006: Determining "People of German Blood", "Jews" and "Mischlinge": The Reich Kinship Office and the Competing Discourses and Powers of Nazism, 1941-1943. Contemporary European History 15, 43-65.

Richau, M. 2007: Die Mormonen - ein umstrittenes Paradies für Familienforscher. Der Herold: Vierteljahrsschrift für Heraldik, Genealogie und verwandte Wissenschaften 50:4, 225-237.

Riehl, W.H. 1851: Land und Leute. Vol. 1 of Die Naturgeschichte des Volkes als Grundlage einer deutschen SozialPolitik. Stuttgart: J.G. Cotta.

Riehl, W.H. 1855: Die Familie. Vol. 3 of Die Naturgeschichte des Volkes als Grundlage einer deutschen Sozial-Politik. Stuttgart: J.G. Cotta.

Ruhri, A. 1997: Die pfarrlichen Altmatriken in der Steiermark. Mitteilungen des Steiermärkischen Landesarchivs 47, 107-138.

Sagnes, S. 1995: De terre et de sang: La passion généalogique. Terrain 25, 125-145.

Schnegg, M., J. Pauli, B. Beer \& E. Alber 2010: Verwandtschaft heute: Positionen, Ergebnisse, Forschungsperspektiven. In: E. Alber, B. Beer, J. Pauli \& M. Schnegg (eds.), Verwandtschaft heute: Positionen, Ergebnisse und Perspektiven. Berlin: Reimer.

Schramm, K. 2008: Struggling over the Past: The Politics of Heritage and Homecoming in Ghana. Walnut Creek, CA: Left Coast Press.
Segalen, M. (ed.) 2012: Parentés et paternités en Europe. Éthnologie Française 42:1.

Segalen, M. \& C. Michelat 1990: L’amour de la généalogie. In: M. Segalen (ed.), Jeux de familles. Paris: Presses du CNRS.

Tucker, S.N. 2009: The Most Public of All History: Family History and Heritage Albums in the Transmission of Records. Ph.D. thesis, University of Amsterdam, http:// dare.uva.nl/record/325290. Accessed March 30, 2012.

Tyler, K. 2005. The Genealogical Imagination: The Inheritance of Interracial Identities. The Sociological Review 53, 475-494.

Vismann, C. 2008: Files: Law and Media Technology. Trans. G. Winthrop-Young. Stanford: Stanford University Press.

Wimmer, A. \& N. Glick Schiller 2002: Methodological Nationalism and the Study of Migration. Archives Européennes de Sociologie 43, 217-240.

Zarri, G. 2001: Die tridentinische Ehe. In: P. Prodi \& W. Reinhard (eds.), Das Konzil von Trient und die Moderne. Berlin: Duncker und Humblot.

Elisabeth Timm is Professor of Cultural Anthropology/ Folklore Studies at the Department of Folklore Studies/ European Ethnology, University of Münster (Germany). Her research interests focus on family and kinship, and comparative approaches integrating historical and contemporary anthropology. Her latest article (with Kathrina Dankl, Tena Mimica, Lukasz Nieradzik and Karin Schneider), "Fault Lines of Participation: An Ethnography Translated into an Exhibition on Family and Kinship" (Museum \& Society, 2013), combines kinship studies and museum studies.

(Elisabeth.Timm@uni-muenster.de) 


\title{
HOW GENDERED IS THE EUROPEAN MIGRATION REGIME? A Feminist Analysis of the Anti-Trafficking Apparatus
}

\author{
Sabine Hess
}

Based on a two-year ethnographic research project on the making of European migration policy, this article explores the ways in which gender is deeply inscribed in the articulations, practices, and rationalities of the new European migration regime. It focuses on the area of "anti-trafficking" policies at national and transnational levels, showing how and why an "anti-trafficking dispositif" has been created over the last twenty years. Anti-trafficking policy, which targets women in particular, has become one of the main pillars of a restrictive, Europeanized migration and border regime. The article offers theoretical and methodological approaches to this gendering of migration policy, and asks what such a co-optation of feminist discourses and practices means for reflexive feminist cultural theory, research, and practice.

Keywords: border regime, anti-trafficking, gender, ethnographic regime analyses

\section{Unaccustomed Alliances: Round Tables on the Trafficking of Women}

I am standing in front of a five-star hotel at the outskirts of Istanbul, only a few minutes from the airport, waiting for my lift. Once again I had endured a two-day political spectacle together with delegates from governments, secret service organizations, the European Union, international and supranational organizations such as Europol, the Organization for Security and Co-operation in Europe (OSCE), and the International Organization for Migration together with national and local non-government organizations (NGOs). For the past six months I had been doing ethnographic fieldwork, applying a multi-sited approach, on policy development within the so-called Budapest Process ${ }^{1}-$ a series of ongo- ing conferences and workshops begun in 1991 on the implementation of EU migration and border policies in areas outside of EU jurisdiction - and held the role of "independent researcher", that peculiar person who somehow belonged at the far end of the table (see Hess 2009, 2010). The Budapest Process and the ICMPD, the International Centre for Migration Policy Development located in Vienna, ${ }^{2}$ which acted as Secretariat for the Process, had caught my attention many years earlier as a key political institution in the area of migration and border management. The ICMPD informs EU Member States, especially new Member States, about policies in these areas and also targeted adjacent countries through workshops and "capacity building programmes" (see Düvell 2002; Hess 2009; Georgi 2007; Geiger \& Pécoud 2010). 
Hosted by Turkey, a broad cross-section of very different organizations - including the Budapest Process, the ICMPD, the United Nation Office of Drugs and Crime (UNODC) and the Black Sea Economic Cooperation Organization (BSEC) - had extended the invitation to the Istanbul conference. The issue at hand was "Trafficking in the Black Sea Region” (UN.GIFT 2007). Surprisingly, despite their diverse interests, the participating institutions had reached a formulaic compromise to rally around the issue of "anti-trafficking", which meant that in the end funds would flow in this direction. Also surprising were the two foci on which participating actors had been able to agree after numerous rounds of negotiation: 1) "transnational cooperation between law enforcement and NGOs for the referral of victims of trafficking" and 2) "data collection and information management" (emphasis by the author).

In my eyes, this conference provided an extraordinary example of the far-reaching impacts and effects of the anti-trafficking discourse (re)produced for years by the EU, the USA, and many international intergovernmental organizations - as well as by regional and local NGOs. At this conference, interagency alliances could be observed that had previously been considered impossible in this region. Concurrently, spaces of possibility had also been opened to an unforeseen extent for formerly marginalized groups and positions, and for the discourses of non-government organizations. For example, estranged but nonetheless at the same table sat the chief of the Jandarma, Turkey's paramilitary law enforcement unit, and representatives of the country's two feminist battered women's shelters. They discussed the limits and difficulties of their therapeutic social work, whereby all NGO representatives repeatedly identified restrictive migration management policies as a major cause of the problem. The OSCE delegate also held an impassioned speech and, after distancing herself from the term "illegal migration" in a very differentiated manner, made clear that restrictive immigration policies and tightened border controls pushed more and more women into the hands of so-called human traffickers ${ }^{3}$ in their efforts to cross the borders as "irregular migrants". ${ }^{4}$
After completing the departure process, once on the plane I wrote in my fieldbook: "The grotesqueries born out of European governance policy are incredible!" As an example: with me in the Jandarma's VW van being driven to the airport were two battered women's shelter workers, clearly anxious and fidgeting nervously in their seats. When we got out I asked them about the cause of their discomfort, and they answered that such vans usually brought them to another destination - namely into police custody after participating in demonstrations. In the context of anti-trafficking policy, these women are now committed members of civil society and not only sit with, but also co-operate with the very same law enforcement institutions. They are unequal actors in the field of anti-trafficking policy, although they understand full well the negative impact of restrictive border policies. Increasingly these alliances, although entry into them may be merely strategic, piqued my interest. In the course of my research on European migration and border policy (2004-2009), I ran into them on the community, regional, and European level - in particular in the context of antitrafficking policy. I wanted to better understand these alliances and take a closer look at this style of setting government policy. I was further interested in the role and function of anti-trafficking policy for the European border regime from a gender theoretical and cultural anthropological perspective. My ethnographic and discourse analysis research therefore focuses on the European context.

The key focal point of this research interest is the international policy field of anti- or counter-trafficking in human beings - especially in women - in the main because it is this migration policy terrain that "works" with discursive positions situated within feminism and women's rights. It is a field which over the past fifteen years has stepped out of the political niche of the international women's movement and become a dominant apparatus within European and globalized migration management. Not only does it legitimize the discourse of tightening migration control, it provides a foundation for this discourse and has a massive public impact. For example, "MTV" and another music TV channel "Viva" 
take part in international campaigns against human trafficking and trafficking in women, and international celebrities such as Angelina Jolie act as international extraordinary ambassadors (MTV 2012; http://news.change.org/stories/latest-big-names-inhuman-trafficking-fight-liu-streep-jolie). ${ }^{5}$ This discourse has also freed very large sums of money for the international fight against organized crime and produced new coalitions of actors such as the one outlined above in which - under the aegis of governments - members of civil society, feminist NGOs, international organizations such as the omnipresent International Organization for Migration (IOM), and national and supranational law enforcement and secret service agencies gather around the same table. Even if the IOM and the International Labour Organization (ILO) have made attempts in the past few years to expand the discourse to include all forms of the exploitation of labour, at the centre of the anti-trafficking apparatus are still the images and discourses of trafficking in women and forced prostitution. Like almost no other international policy area, it focuses on the female body and female sexuality - in particular on the topos of the helpless female "victim". ${ }^{6}$ For this reason, an analysis of the anti-trafficking apparatus can also reveal how deeply the category of gender is inscribed in the procedures, technologies, articulations, and rationales of modern European migration policy.

Based on Michel Foucault's ideas, I speak of the "anti-trafficking apparatus" (dispositif). ${ }^{7}$ Foucault, in Reiner Keller's estimation, introduced the concept of the apparatus following his discourse theory work in order to connect studies of the said with studies of the unsaid: of materials, infrastructures, and institutional actions (Keller 2008: 93ff.). In this vein, I am interested in an analysis of the linkages of policies and discourses, especially of their rationales and their impact in terms of power and discourses of truth. I am also concerned with the function and relevancy of these linkages in relation to European migration policy. To this end, I look at the way in which the apparatus of "anti-trafficking policy" plays a central role in policies governing tightening border controls and the externalization of the European border regime. It shall become clear that the current turn towards "governance" within the migration regime is also built upon these discourses of victimization and uses discursive positions of the human rights' and women's movements in its argumentation (see also Hess \& Karakayali 2007). I shall also show how new governmental political practices and discourses are connected to this apparatus - such as the politics of round-table meetings - with very ambivalent effects on, among other things, feminist political practices. I am particularly interested in understanding how discourses of women's rights - in particular positions against violence against women - came to fit so well with the restrictive rationalities of the border regime. This leads me to ask in the final section what it means when feminist theory and practice act on the terrain of migration and border policy. I also try to pinpoint those discursive positions - including research on women and migration - which help(ed) produce this adaptability. ${ }^{8}$

In the following I draw mostly from the interdisciplinary approach of Anglophone queer and genderaware research on immigration and border management such as the work of Bridget Anderson (2009) and Rutvica Andrijašević (2009, 2010), as well as from Foucauldian and post-colonial debates on the refashioning of Europe. I also draw from the results of my own research on European migration and border policy such as the work mentioned above (Hess $2009,2011)$, the interdisciplinary research project Transit Migration (2003-2005), and research conducted within the Network of Critical Migration and Border Regime Research (Hess \& Kasparek 2010). Within the framework of the collaborative Transit Migration research project ${ }^{9}$, we conducted ethnographic research at the southern and eastern borders of the EU on the Europeanization of migration policy. Building on this research, we developed what we called an "ethnographic border regime analysis" (Hess \& Tsianos 2007). This ethnographic border regime analysis connects more recent approaches to ethnographic field research - in particular variants of multi-sited ethnography (Marcus 1998) - with genealogical and discourse analysis approaches (Hess \& Tsianos 2010). In terms of content and theory, it 
attempts to look at the developments of migration policy from the perspective of migrants' movements and also to develop a form of praxeological policy research capable of analysing "doing border" (see Hess, Karakayali \& Tsianos 2009; Ferguson \& Gupta 2005; Shore \& Wright 1997). In our Transit Migration fieldwork, we identified the discourse of asylum and the discourse of anti-trafficking - and the actors and practices associated with them - as the central discursive and legitimizing pillars of European migration and border management policy. Eva Bahl and Marina Ginal, in their ethnographic research on the local adaptation of anti-trafficking policy in Munich, Germany, were able to show how this discourse has a strong normative effect on what could be expressed and what was unspeakable. For example, it makes it almost impossible to talk about migrant sex work unless it can be subsumed under the topos of sex trafficking and forced prostitution (see Bahl, Ginal \& Hess 2010). ${ }^{10}$

However, before going into the interplay of the Europeanization of immigration policy and the discourse on trafficking in women, I would like to first outline the genesis of the anti-trafficking apparatus. Below I sketch its varying disciplinary components and dominant dichotomous discursive strategy in an attempt to identify the factors leading to the "boom" in this sector.

\section{Genesis of the Anti-Trafficking Apparatus}

There are very few other political discourses and arenas of praxis in which the female migrant body is so explicitly the central object not only of numerous discourses and fears, but also of exploitative relations, of violence, and of a package of quite contradictory countermeasures. It is at the centre of feminist anti-violence politics advocated by activists who have successfully devoted decades to creating a public scandal of the issues of forced prostitution and sex trafficking of women and to promoting feminist protective measures developed to provide concrete support and care. These support practices run the gamut from charitable church measures to radical feminist and anti-racist approaches, from abolitionist to empowerment positions (see Andrijašević
2010: 2, 14f.; Karakayali 2008), and are clearly divisible according to whether migrant women are given the status of objects or subjects/active agents (see, e.g., Lindqvist 2007).

Historical research on the genesis of the discourse of human trafficking such as Serhat Karakayali's work on the politics of irregular migration (2008) or Eval Bahl, Marina Ginal, Bernd Kasparek's joint work on urban migration policy discourses (2009) reveal through their reconstructions a series of thematic shifts and, in Germany, three clear time periods: In the first period at the beginning of the twentieth century, as mass immigration into and out of Germany was the order of the day, the discourse was widespread and also focused in the main on immigrant women. Warnings about the danger of forced prostitution were published in leaflets and on posters. During this period for example, the Bahnhofsmission (church travellers' aid association) was founded for the protection of young women travelling alone (see Hess 2005). This discourse again became virulent in the 1960s and 1970s at the height of labour migration in the context of the so-called guest worker (Gastarbeiter) system. However, in this period, neither the immigration of women nor the sex industry was at the centre of the narrativization. Rather the conditions of self-organized and irregular labour migration were criticized. Working conditions in factories and on construction sites were termed "slavery" and the exploitative practices of labour recruitment agencies were condemned as "human trafficking". Serhat Karakayali points out that at this time too, left-wing poeple - advocated in this case mostly by trade unions - portrayed the situation as a scandal in order to give the discourse more impact (2008: 235). Anti-trafficking discourse died down again in the 1980s as Germany presented itself as a "nonimmigration country" and reappeared in the 1990s as a discourse about women as debates increased on the increase of immigration, in particular from Eastern Europe and the global South.

The renewed interest in this issue by policy makers in the 1990s was the fruit of decades of campaigning by feminist and women's groups to have sex traffick- 
ing taken seriously. The struggle against the trafficking of women and children and the struggle against forced prostitution, closely linked on the discursive level, were placed on the political agenda in particular because of the focus on these issues at the UN human rights conference in Vienna in 1993 and the UN World Conference on Women in Beijing in 1995 (Schwenken 2006; Düvell 2002). On the EU level, the political scientist Helen Schwenken (2006: 111) has underscored the importance of what she termed the "velvet triangle" of so-called femocrats (feminist bureaucrats), scientists, and activists/lobbyists in establishing this discourse in the 1990s. The European Union, after receiving the mandate to become active in the areas of justice and home affairs and legal issue in the treaties of Maastricht (1992) and Amsterdam (1995), worked closely together with NGOs and other lobby groups and profited from their expertise and knowledge. These new EU structures gave political women's networks in particular a chance to establish a hegemony for their positions - mostly through the Women's Office (later the Equal Opportunity Unit) - especially if these positions were presented as gender equality issues. The issue of trafficking in women profited greatly from this window of opportunity and feminist groups were increasingly able to put it on the political agenda during this period.

The first EU action programme against trafficking in human beings was the 1996 STOP programme (Commission of the European Union 1996). In this programme, the EU stresses that it brings together a broad spectrum of actors including "universities, NGOs, police and immigration services, government and parliaments" (ibid.). The next communication about the programme also underscored the broad spectrum and heterogeneity of the actors with whom the EU commission was able to work in this area, naming in particular cooperation with "nonmember countries and specialised organisations" (Commission of the European Union 1998). This communication refers to other action programmes and forums within which the issue had been dealt with in the previous years:
The fight against trafficking in human beings has also been tackled in the United Nations (special Protocol to the International Convention against Organised Transnational Crime), the G8 (action plan), the Council of Europe, the International Organisation for Migrants (IOM) (regional surveys and information campaigns), Interpol, the Organisation for Security and Cooperation in Europe (OSCE) and in the context of the transatlantic dialogue. (Ibid.)

A further EU action programme, Daphne, ensued in 2000 (Commission of the European Union 2000). Daphne provided funding for NGOs that offered support to women and children who had been victims of trafficking. And two years later, in 2002, the Council of the European Union adopted a framework decision to establish a common legal framework on human trafficking within the Member States (Council of the European Union 2002). ${ }^{11}$ Daphne I and II were extremely instrumental in strengthening the anti-trafficking discourse and the relevant actors. Where no NGOs had previously existed, they were created and, as our research within the Transit Migration project showed for the example of Turkey and the Balkan states, influence was exerted on the political programmes of existing NGOs. In an interview with the Berlin anti-racism organization AntirassismusBüro, Marion Böker from the Federal Association against Trafficking in Women and Violence against Women in the Migration Process (KOK) criticized the fact that the EU's grant programmes contributed greatly to splits in the NGO community between those initiatives which were willing to work together with the EU on victim protection measures and round table politics and those that rejected cooperation or collaboration with government law enforcement agencies and therefore did not receive financial aid (Böker 2004).

Concretely, within EU migration and border policies, two arenas of political practice emerged in the area of anti-trafficking policies. This can be seen in other areas of the world as well, for example in the so-called Bali Process in the Asia-Pacific region. Anti-trafficking politics thus act in an arena of high- 
profile politics of representation, and establish a very specific regime of the gaze of the female body. Concurrently, especially in the area of security, these policies are enacted as a part of the overall increasing efforts to combat irregular migration and organized crime.

We should first examine the politics of visualization which create a racialized and sexualized regime of the gaze and has a negative impact in particular in female migrants' home countries, because it places the migration of women in general under the moral misgivings surrounding prostitution and stigmatizes women's migration as, among other things, a risk which cannot be taken (see Hess 2005). This takes place mostly within so-called awareness-raising or educational campaigns that warn of the dangers of human trafficking on large billboards and other advertising media in the home countries. The International Organisation for Migration (IOM), one of the few global all-around agencies in the field of migration control, is particularly active in this area (Düvell 2002; Georgi 2010). ${ }^{12}$ Rutvica Andrijašević conducted an analysis of the images used by the IOM in their 2001-2002 campaign in the Baltic States. As in other IOM campaigns, this Baltic campaign made use of images of usually naked female bodies posed as victims. One poster, for example, portrays a halfnaked female body hanging in the air on hooks and ropes. These images are meant to warn potential migrants of the dangers of migration and prostitution (Andrijašević 2005). IOM's Head of Mass Information put it as follows:

The nakedness was meant to show the helplessness and vulnerability of trafficked women. The hooks are visual metaphors used to convey an essential aspect of trafficking, namely the manipulation and exploitation to which trafficked women are subjected (...). Most trafficked women find themselves treated as slaves with no control of their lives whatsoever. This is the idea we wanted to convey. (Cited in ibid.: 35-37)

Stressing the dangers of migration, in Rutvica Andrijašević's analysis, is meant to keep women away from informal labour migration and "implies that the safest option is to remain home" (ibid.: 31). Furthermore, Andrijašević shows that the male voyeuristic gaze is inherent to these images, constructed as they are of women's suffering and victimized bodies. This degrades them to objects of voyeuristic eroticization, thereby reproducing the stereotype of Eastern European women as "beautiful victims". In light of this, Andrijašević shows that the campaign is not about, but rather against, women and women's migration and transports the message: stay at home!

Global anti-trafficking policy, alongside large public relation campaigns such as this one - campaigns in which Viva and MTV also sometimes participate - has otherwise been rooted mostly in the terrain of security and migration management policy. Combating sex trafficking takes place mostly in connection with the fight against organized crime, thus correlating the two. The UN protocol, considered the central document of anti-trafficking policy, illustrates the way in which sex trafficking was made into a security issue. The protocol was celebrated - also by feminist activists - as a milestone in bringing the issue onto the official European and global political agenda. The so-called Palermo Protocol was adopted by the United Nations Office on Drugs and Crime in 2003 as a supplement to the broader Convention against Transnational Organized Crime (UNODC 2004). It is thus primarily a political instrument to improve international cooperation and develop a new international legal regime in the fight against organized crime. The protocol differentiates between trafficking (forced trade) and smuggling (voluntary migration). On the one hand this is laudable, because it allows for differentiated interpretations - not all transport and information services in this area should be automatically defined as "trafficking". On the other hand, the Convention strengthens and formalizes the central dichotomy between voluntary migration and force which characterizes this discourse. Christina Hahn conducted a reconstructive discourse analysis of the positions of various NGO-affiliated lobby groups in this area. She showed how abolitionist positions increasingly gained hegemony that treated women migrants, es- 
pecially sex workers, as defenceless victims without a voice (Hahn 2007).

However, biographically-oriented ethnographic research in this area has shown that the reality of these women is different. In their daily lives, voluntary actions and direct and structural violence intersect in contradictory manners and are judged and negotiated in myriad ways, both in migrants' interpretations and in their actions. Ramona Lenz for example, in her study of mostly Filipina and Eastern European sex workers in Cyprus, shows how these women arrived in the country on their own with an official artist visa and only later, as a result of having no rights, drifted into relations characterized by dependency and coercion (Lenz 2009). On the other hand, women interviewed by Rutvica Andrijašević for her study about Eastern European sex workers in Italy, describe how they chose to work as prostitutes and themselves turned to trafficking networks and at the same time say they were forced. Nevertheless, the women interviewed in this study clearly developed strategies to deal with dependency and coercion (see Andrijašević 2010).

\section{Boom Sector Sex Trafficking: Migration Policy as a Catalyst}

Numerous studies have shown that over the past years, demand has increased for sexualized and racialized women's bodies and emotion-laden sexualized work in the context of globalization and economic restructuring (see Andrijašević 2010: 5ff.; Hochschild 1983). Feminist scholars search for the causes in the heteronormative, patriarchal, capitalist, and racialized world order. Sex trafficking, the trade of women and children for the purpose of sexual exploitation, is now, according to international law enforcement agencies such as Europol, the fastest growing criminal sector. After the drug and arms trade it is also, according to some, the third most profitable sector (see for example Andrijašević 2010: 7). However, since statistics are problematic in this area, ${ }^{13}$ because of the informal character of the phenomenon and the different statistical methods used by different authorities, the authors of the study "Human Trafficking in Germany" cite Europol as follows:
Europol assumes that "hundreds of thousands" of victims are trafficked into the EU Member States each year for the purpose of sexual exploitation and labour exploitation and notes that the number of victims has increased considerably over the past few years. (Cited in Folmer \& Rabe 2009: 20)

Feminist studies with a biographical and ethnological orientation have pointed out that stereotypes of the impoverished woman from the global South and East together with increased male demand in the North create a push-pull model that does not do justice to the complexity of this field, which is not only economic, but also social, cultural, and political. These studies show that subjective, emotional, and ethical aspects such as the women's own ideas about sexuality and a better life as well as their rationalizations must be given more importance in order to place more weight on the agency of the migrant women themselves (see for example Andrijašević 2010: 12; Hess 2005).

Andrijašević also shows how the spread of the sector is connected to the general increase in underpaid labour in deregulated and informal sectors following the flexibilization of labour policies in the Western and Northern countries. This went hand in hand with an increased demand for an inexpensive and flexible female migrant labour force, leading to the feminization of migration which can be observed in many southern and eastern countries (see for example Anthias \& Lazaridis 2000). However, for most of these migrants, because of restrictive immigration and labour policies in most EU countries - and in connection with racialized images of (still) female (domestic) workers - the only field open to them is the large field of caretaking; including care for the sick and elderly, cleaning and ironing, domestic and childcare services, and also sex work (see Lutz 2007). This labour segment of the three Cs (cooking, cleaning, caring $)^{14}$ is very gender-specific. It often falls under the "private" sphere and is thus not subject to public scrutiny or formalized labour contracts (ibid.). Ethnographic and biographical research has shown that this is also a factor which migrants often use to their advantage (see Hess 2005; Lutz 2007). 
Alongside these subjective biographical and political-economic factors, researchers also point out a genuinely political regulatory factor which has led to the increase in the nexus of migration-trafficking-sex work: official European immigration policy itself. Without this regulatory influence, which to this day can only be described as restrictive and gendered, the phenomenon of sex trafficking could not possibly be as widespread as it is today. For example, most countries allow very little official immigration and immigration laws reflect a view of migration as a male undertaking focused on male labour (see Hess 2005). Feminist and queer research on migration has been able to demonstrate the way in which immigration policy is based on heteronormative concepts of gender and sexuality, in particular that of the dependent wife who is not herself actively seeking migrant status. Policies geared towards the reunification of families or regulations granting the right of residence as a result of marriage - two ways in which women often gain legal immigrant status - reproduce heterosexual patterns and female dependency (Kofmann \& Sales 1998; Andrijašević 2009: 394). Because of these immigration and labour market policies, women migrants are overrepresented in precarious and informal migration and labour sectors. In the end, policies that grant only few residency and work permits - which are moreover temporary and uncertain - create marginalized groups of migrants without any meaningful access to the formal labour market and without recourse to law. Within this logical framework, "illegal" immigrants are not an abnormality or an outgrowth of the system, but rather a constructed, regulatory category of immigration.

In order to further this restrictive migration policy, which creates hierarchies and puts migrants in precarious situations, over the past two decades European border management has been harmonized and continually intensified using diverse (military) apparatuses and practices of knowledge and technology. Images of drowned immigrants in the Strait of Gibraltar and the Aegean and Libyan Sea or of military patrol boats belonging to the European border control agency Frontex are only the apex of a technological/military apparatus that, in the name of "migration management", works towards the selection of immigrants to maximize benefits (see Ghosh 1997; for a critical analysis see also Mezzadra 2009; Geiger \& Pécoud 2010; Hess \& Kasparek 2010). In sum, it can be said that it is European immigration and border management policies themselves - as has been acknowledged at EU conferences as well - which have helped further the phenomenon of sex trafficking, because migrants are dependent upon the services of trafficking and smuggler organizations in order to cross the border at all. When migrants do manage to cross the external borders, ${ }^{15}$ immigration policy paired with nationalist, racist labour market policies ${ }^{16}$ and heterosexist gender policies push women towards informal (sex) work sectors and produce dependencies and disenfranchisement.

\section{The European Border Regime and the Role of Anti-Trafficking Policies}

In the public mind, the Europeanization of migration policy is closely connected to the name of a small village in Luxembourg. In Schengen, five Member States of what was then the European Community, including Germany, met in 1985 on a multi-lateral level and outside of EU structures to establish a common market. As a so-called compensatory measure, they agreed to shift border controls to the outer borders and to harmonize policies regarding refugees, foreigners, and visa practices. But it took over ten years before the Schengen Agreement became official EU policy in the 1998 Treaty of Amsterdam (see Hess \& Tsianos 2007; Hess 2010). ${ }^{17}$ Although the harmonization of EU migration policies is a sluggish process, harmonization and consensual immigration control practices can be observed, known in EU jargon as "integrated border management" (see Geiger \& Pécoud 2010).

A central characteristic of this policy is the externalization and internalization of borders. "Borders" have now been placed far beyond the actual borders of the EU and have also been defined within EU territory, producing flexible, fragmented border areas and border corridors which are enacted in a highly 
technocratic manner (Walters 2002; Tsianos 2008). On the European Commission level, this transformation of the border regime is expressed discursively and operatively through a focus on "migratory routes" (see Commission of the European Union 2007). The Commission's 2007 communication states: "However, applying the Global Approach to the Eastern and South-Eastern regions neighbouring the EU according to the concept of 'migratory routes' also requires consideration of countries of origin and transit further afield" (ibid.: 247). This approach no longer focuses on the crossing of national borderlines, rather it is the migratory movement itself - in particular the routes taken by migrants - that is at the centre of these control policies. This leads to a massive imperial extension of European immigration policy into migrants' home countries. In this context, the discourse on smugglers and human traffickers takes on a key operative function that is not limited to exposing and shutting down smuggling rings and human trafficking routes. This act of putting immigrants under general suspicion, or rather the linkage of migration and criminality, provides regulatory bodies with the legitimation they need to detain all migrants and interrogate them - using violence at times - about their routes. Pro Asyl has documented this practice in Greece (Pro Asyl 2008). In this way, large data sets are generated and visualizations of migration patterns are produced such as the so-called i-Map, a digital map of migration routes created by Europol, Frontex, the United Nation High Commissioner (UNHCR), the UNODC, and the ICMPD (see i-Map 2012).

Even if the harmonization of EU migration policy has faced many setbacks (see Birsl 2005), the Europeanization of migration management has nevertheless developed an internal dynamic. As we were able to show in our research project Transit Migration, this can be traced in the main to the formation and activities of innumerable international, regional, and local actors who both support and flank government policies, and who are also miles ahead of them and are following their own political agendas. This multiplication of actors is known in international border studies as "privatization", and is called the politics of "remote control". European border policy is thus also made outside of government institutions and far from national borders (see Lahav \& Guiraudon 2000; Guiraudon 2001). Within Transit Migration, we termed this process "NGOization" in order to make clear that this method of governmental policymaking takes place mostly through and in cooperation with NGOs, and itself takes on elements of an activist repertoire (see Hess \& Karakayali 2007).

The two largest intergovernmental organizations in this field are the UNHCR, whose existence goes back to the Geneva Convention on Refugees (see Ratfisch \& Scheel 2010), and the above-mentioned IOM. In contrast to the UNHCR, the IOM has no foundation in international law, although it makes great efforts to performatively generate such a foundation. As our ethnographic research in Transit Migration made clear, the exploitation and hegemonization of the anti-trafficking discourse played a key role in the IOM's ability to secure its dominant position in the global arena. Combatting human trafficking is, alongside refugee policy, one of very few areas of migration policy which uses a discourse promising protection and is pushed forward in the main by the USA (see US Department of State 2012), which in turn set the course of the IOM. As we have seen in the example of the Istanbul conference, antitrafficking discourse is also reproduced by further large and small institutional actors in the migration management arena from the OSCE to small NGOs on the local level (see Migmap 2006).

\section{New European Governance - Turning the Border Regime into a Human Rights Issue}

This multiplication of key players and inter-agency cooperation correlates directly with changes in the European Commission's political practice as laid out in detail in the White Paper on European Governance (Commission of the European Union 2001). As a response to global challenges, the Commission writes, politics should be "decentralized" and shaped at "various levels" within "networks", include the strategic "involvement of civil society" and the use of "expert advice". The findings of the 
Transit Migration project on the political practices and discourse of immigration policy as expressed by the EU within the preliminary rounds on the accession of Turkey, show that the politics of the "Round Table" is the incarnation of the politics of governance (see Bahl, Ginal \& Hess 2010).

On a discursive level, these new coalitions - as I have described using the example of the Istanbul conference - adapt the discursive positions of human rights activists and feminists to a restrictive border regime. William Walters, a researcher of Europeanization and border management, speaks in this context of the "Birth of the Humanitarian Border" which does not necessarily mean that actual practice becomes more humanitarian (Walters 2010). However, local ethnographic research such as Marc Speer's work on the implementation of the EU border regime in the Ukraine (2010) shows that human rights interventions and activists can in fact challenge law enforcement structures. But the price is often high, as players must accede to the logic of a human rights discourse which, among other things, seems to demand the choice of a policy approach that victimizes the migrant other. Eva Bahl and Marina Ginal come to the same conclusions in their study on the effects of the anti-trafficking discourse on negotiation options and positions on the municipal level. They clearly show the way in which this discourse delegitimizes empowering positions and only an abolitionist, victimizing discourse remains as the legitimate manner of speaking about, or having knowledge about, migrants in sex work (see Bahl, Ginal \& Hess 2010).

Thus during the Istanbul conference, all key players spoke of a "victim oriented approach". This is a significant shift in the discourse and moves the focus away from law enforcement and concrete practices of control. Rather, within this discursive shift it seems that all institutions of political control are interested in protecting the victims and posit themselves as biased, almost activist players concerned primarily with the well-being of the women involved. Yet the measures taken in the name of victim protection include stopping and identifying trafficked women, taking them into police custody and interrogating them about their migration routes, placing them at women's shelters for the protection of victims, having them appear as court witnesses, and deporting them back to their home countries. The ICMPD, an organization which has played a key role in furthering this discourse, published interviews with women who had undergone these procedures in a study entitled "Listening to Victims" (Surtees 2007). In this study, the ICMPD - which does not have a reputation for doing pro-immigrant work - cites many women who tell of inappropriate and poor conduct by both the police and NGOs who scared them, threatened them, mocked them, and did not explain their situation to them. Many passages also cite migrant women clearly stating that the measures taken in order to protect them were not what they wanted, and that actions which go by the name of victim protection are actually against their interests. The following passage is one example: "It happened for the first time when I heard that I could not have residence papers and must leave from the centre. I fainted and when I was awakened I started to scream... I did not want to leave the centre; I had no place to go" (ibid.: 110). Many quotes in this section describe the women's distress at and rejection of their repatriation. In this context, the work of NGOs, women's shelters, and the IOM is particularly politically charged, since they support the detained women throughout all procedures up until repatriation. They may try to alleviate the migrants' situation by giving them financial start-up grants or arranging contacts to women's shelters in their home countries, but this is often not what the women themselves want. They want to remain as migrants in the new country.

\section{Anti-Trafficking as the Motor of a Restrictive Border Regime}

All in all it can be stated that this package of measures, encoded as victim protection, makes the female migrant body the central target of diverse and connected high-tech practices of knowledge within the migration and border regime, up to and including local NGOs and ending in operative mappings of migration routes such as the so-called i-Map. The i-Map is the brainchild of ICMPD, Frontex, and 
Europol. On the surface it shows a digital map that claims to portray current migration routes based on databases (i-Map 2012). The UNODC and other law enforcement agencies continually create data sets and visualizations of this type in the vain hope of being able to make accurate prognoses about migration movements. Victim protection measures objectify the migrant body; they make it penetrable and computable, subject to categorization and selection. More than anything, they limit the migrants' histories to their status as victims. We imagine "victims" as defenceless women, reduced to their corporeality and no longer able to speak for themselves. They must be protected from themselves - in our Transit Migration research we even learned of a women's NGO in Belgrade which locked women in "for their own protection". Migrant sex workers are only interesting for social work organization as victims. Migrants who voluntarily become prostitutes and are then confronted with a situation in which they are subordinated and exploited often have no recourse to support.

Looking at all of this together, we see a convergence between anti-trafficking polices and anti-immigrant policies. As a result, even policies that operate in the name of helping victims in the end act against the interest of women from the European periphery. In sum, the central discursive impact of the anti-trafficking discourse is that it 1) not only legitimizes, but also demands more stringent control of migration to protect possible victims; 2 ) on a practical level, legitimizes the creation of so-called screening centres which are set up along migration routes in order to filter out "vulnerable" trafficking victims and refugees from the mass of irregular labour migration. As a result, the anti-trafficking discourse furthers a policy of selection, and concomitantly the criminalization and disenfranchisement of most immigrants without papers, who can be categorized neither as trafficking victims nor as refugees. In the end, antitrafficking policy thus plays a key role in the ascendency of this key biopolitical mechanism of hierarchizing and disciplining migrant passages by means of border management policy (see Mezzadra 2009). ${ }^{18}$ Finally, the anti-trafficking discourse 3) legitimizes police practices of detainment and thorough interrogation meant to uncover migration routes and trafficking networks, and ending in numerous processes of knowledge acquisition as exemplified by the i-Map. For this reason, Rutvica Andrijašević comes to the conclusion that "trafficking discourse and anti-trafficking policies sustain and normalise a differential regime of mobility through which the EU hierarchically organises access to its labour market and citizenship" (Andrijašević 2010: 4). Researcher and sex worker activist Jo Doezema therefor asked at a 2002 conference on trafficking at the university of Ghent: "As trafficking is increasingly being used by governments and even by NGOs as an excuse for repressive policies, NGOs are left wondering: where did we go wrong?" (2003: 1).

\section{On the Biopolitical Logic of Feminational Discourses ${ }^{19}$}

Against this background, I would like to end with an examination of how it was possible that wellmeaning feminist theories and practices - such as those surrounding trafficking in women and forced prostitution - were able to cooperate so easily with restrictive migration and border management policies or rather be coopted by the same without greater friction. I draw on the one hand from the work of the feminist migrant anti-violence activist and theorist Esra Edem, who has conducted an analysis of a similar migration issue - integration policies (Erdem 2009: 190, 192). I also draw from the work of the American queer theorist Jasbir Puar, in particular her book Terrorist Assemblages: Homonationalism in Queer Times. Puar observes a similar discursive coalition in the US "war against terror" in which the "terrorist assemblage" integrates discursive positions of the gay and lesbian movement. Puar shows how the normative figure of homosexuality is integrated into a post-liberal, post-colonial construction of the "modern" Occident contrasted with a pre-modern, traditional, and patriarchal Orient. She also speaks of an emerging "homonationalism" 20 which is able to build discursively upon the new-found national unity in the war against terror (see Puar 2007).

Esra Erdem uncovers a similar development in 
German integration policy. She describes the way in which gender equality positions have been used in past years in order to legitimize restrictive integration policies. ${ }^{21}$ In this case, a feminist anti-violence against women discourse - expressed by German and immigrant women's rights activists such as Alice Schwarzer or Seran Ates as well as by conservative politicians - is used to suddenly impart the equality of women the status of a Western cultural value (Erdem 2009: 189). Erdem asks what it means for the women's movement (and the theory thereof) that it has become a central actor on the terrain of foreigners' rights and that it encourages a discourse and images which place migrant women predominantly in the context of violence, as passive victims who are incapable of action.

Erdem goes on to argue that this feminist-inspired anti-violence policy not only chases after a liberal feminist illusion that jurisdiction and stricter immigration laws could protect women (ibid.: 191), but also that such policies are too reductionist and in the final analysis, racist. They ignore the intersections of other power relations such as policies on immigration and "aliens" or the colonial geographies of the gaze in which this discourse and the speakers' positions are located. Within the context of the debate on integration, as in the context of the US war against terror, the primary topoi, albeit radicalized, are colonial and Orientalist images of the modern Occident and its counterpart, the traditional Orient. From the very beginning of the colonial project, the relation of the sexes, in particular the figure of the subjected wife and the narrative of honour killings, have been used to prove the myth of Western modernity and Eastern (and Southern) traditionalism (see von Braun \& Mathes 2007). Chandra Talpade Mohanty (1998) for example has shown that the production of the topos of the oppressed woman of the global South was constitutive for the production of the "emancipated Western woman". Gayatri Chakravorty Spivak argues similarly (1990) when she positions work done by Northern feminists for Southern women within paternalistic mission work. Thus national Western feminist discursive positions have a long tradition of legitimizing both the busi- ness of German colonialism and the project of the nation-state, and of putting itself at the service of these projects. Esra Erdem calls those feminist discursive positions which today are inscribed within restrictive debates on integration "racialized gender equality politics" which support the "codification of a racialized hierarchy (...) established by laws on aliens" (Erdem 2009: 191, 195). She speaks further of the "feminist disciplining of the migrant subject" (ibid.: 194), which found legitimatization and a quasi-scientific source of knowledge in, as I shall show in my final section, women's studies and gender migration studies.

\section{The Discourse of Victimization and Feminist Migration Studies}

In contrast to the ubiquitous thesis of the invisibility of migrant women, especially in feminist migration studies, in general migration studies show how migrant women receive specific visibility as an object of knowledge and are central to processes of positing migration in cultural and ethnic categories. An unsystematic genealogical look at the history of the analysis of migrant women demonstrates the way in which certain discourses - in particular the topos of women as victims and the discourse of victimization - have a long tradition in feminist migration studies.

Not only Ernest George Ravenstein noted in the 1885 Journal of the Statistical Society: "females are more migratory than males" (Ravenstein 1885: 196). In The Polish Peasant in Europe and America, a work that is influential in the social sciences to this day, the Chicago sociologists W.I. Thomas and Florian Znaniecki also include the experiences of women immigrants. However, Helma Lutz was able to show that, in contrast to their portraits of male immigration, portrayed as actively breaking out of the past, women are described quite differently in The Polish Peasant. As Lutz says: "For women, they write, migration is a calamity" (Lutz 2008). The topos was born of the female migrant as a "victim" dependent upon her family, a topos which - Lutz claims made an impressive comeback in labour migration research in the 1970s. One of the pioneers of research on women migrants, Mirjana Morokvasic, noted as 
early as 1984 on the dominant representation of migrant women:

In important works on migration, the symbolic reference to women as migrants' wives and their stereotypical presentation as wives and mothers has led to a conceptualization of migrant women as followers, dependents, unproductive persons, isolated, illiterate and ignorant. (Morokvasic 1984: 16)

In German research, Umut Erel and Eleonore Kofman have shown that the dominant topoi are the "passive wife and mother" and the "victim of patriarchal honour codes" (see Erel \& Kofman 2003). From the very beginning of research on labour migration, these topoi, and the concomitant images of the "defenceless female body" and "women as carrier of culture" played an epistemological role in the general theoretical concept of "migration". These topoi were taken up in processes of cultural and ethnic identification within the social sciences and used to link labour migration with backwardness and patriarchal structures.

This early image of women's migration has a further discursive effect which influences academic and everyday thinking to this day: it implies coercion and dependency and ignores subjective aspects of women's plans for migration - their hopes and desires. The research on women's migration which began in the 1980s, initially meant as a supplement to academic research on migration, helped to continue this ambivalent pictorial history. In particular in the addition of the issues of (forced) prostitution and migration via marriage (see for example Hummel 1993; Schöning-Kalender 1989), this research sector took up the metaphor of the passive victim until biographical studies began to bring the women themselves and their narratives to the centre of study (Karrer \& Turtschi 1996).

This victimizing approach was however continually criticized by feminist migrants such as, for example, Sedef Gümen (1996) beginning in the 1980s. Meanwhile, refutation of victimization approaches is standard anti-racist, feminist rhetoric. Neverthe- less, this approach, as Helen Schwenken has shown in her dissertation on strategies for the mobilization of domestic workers on an EU level, it is still considered as a successful means of framing political demands. Thus some types of institutionalized feminism still consciously work with the topos of victimization in their political actions, even if the migrants themselves, as Ramona Lenz has shown in her research on Cyprus, need to be convinced of their victim status. One Cypriote women's right activist even uses these very words: "We have to convince them that they are victims" (Lenz 2009). Migrant women themselves also, if not always intentionally, make use of an image of themselves as victims, because they know that the apparatus of victimization is one of their few options within the Western, "humanist" sphere. Paradoxically, sometimes claiming the status of victims and framing themselves as victims is the only way to become a subject and develop a position as a protagonist.

Given the way in which the feminist discourse and practices I have looked at in this essay are almost tailored to fit the racist discourse Philomena Essed has termed "Europism" (1995), and their increasing visibility within and co-optation for racialized policies of regulation, I would like to end by concurring with Esra Erdem's final thoughts. She has identified the recognition of the "struggles of migrants and of feminism" and building upon the same to create a progressive vision for a society open to migration as one of the central challenges for the German women's movement and feminist research. In cultural anthropological research this would mean rethinking the knee-jerk association of migrant women with misery and suffering, because, as we have seen, despite researchers' best intentions these images have a clear function in a hegemonical, restrictive border regime. Rather we should begin anew and ask which knowledge and which images would allow a critical analytical reflection on this policy.

\section{Notes}

1 The Budapest Process is a so-called regional consultation process or "informal dialogue" in which mostly eastern and southern European countries - and more recently also Caucasian countries - bring international 
organizations and non-government organizations (NGOs) together to convey the logic, practices, and technologies of European migration and border management policies and to train participants in the same (see ICMPD 2012a). Since the beginning of the 2000s, the ICMPD has hosted a further informal dialogue focusing on African and Middle Eastern migration, the Mediterranean Transit Migration Dialogue (see ICMPD 2012c).

2 The ICMPD, founded in 1993 on the initiative of Switzerland and Austria in particular, is today one of the leading consultants for migration policy in Europe. It boasts fourteen member states and employs around 60 people in its Vienna office (see ICMPD 2012b).

3 In the area of women's migration, and occasionally also in the area of undocumented labour migration, the terminology used most is "forced" trafficking in humans; in the area of refugees, there are "smugglers" and "labour brokers", terms that clearly do not imply coercion and trickery (see Karakayali 2008). However, within the public discourse on refugee and asylum policy, investigative practices, technologies, and expert knowledge aimed at reconstructing travel itineraries are also common in dealings with refugees in order to judge applicants' "right to asylum" and whether they are telling the "truth".

4 The term "irregular migration" seems to have gained ascendency in the European political arena as the "politically correct" phrase. However, in research on migration in the cultural and social sciences, a more thoroughgoing process-oriented debate about terminology is taking place which makes it clear that the situations of un(der)documented migrants - that is those without identification documentation and legal status - are in flux. Most common is a continuum of legal and "illegalized" statuses which can take different forms in terms of irregularities in residency and working permits. Migrants themselves deal flexibly and tactically with these statuses (see for example Vasta 2008; Karakayali 2008; Hess 2005).

5 This entrance of anti-trafficking policy into popular culture can be found in other forms of pop culture as well, in particular TV cop shows.

6 To avoid any misunderstandings, I would like to stress that trafficking in human beings and the resultant slave labour and forced prostitution are abominable and must be combated. This is an informal economic sector, often criminal, that is quickly growing around the world. However, legal action against this sector would be quite possible under existing legal frameworks and without migration management policies.

7 According to Reiner Keller, Foucault uses the term "dispositif" to refer to "an infrastructural apparatus made up of varying elements" and meant "to serve a particu- lar purpose" (see Keller 2008: 93), whereas Foucault himself defined it as the "system of relations that can be established between these elements" (Foucault 1980: 194). On the other hand Foucault understood the dispositif as a "formation which has as its major function at a given historical moment that of responding to an urgent need. The apparatus thus has a dominant strategic function" (ibid.: 195, emphasis in the original). These are the meanings which I have ascribed to the dispositive/apparatus.

8 It is this discussion of the (susceptibility to) co-optation exhibited by feminist theory and practice as well as the search for a progressive feminist politics of knowledge - leaning on Donna Harraway's postulate of "situated knowledge" - which positions this study in a continued process of feminist query as to how feminist theory and practice today can be articulated in an intersectional manner, critical of power and hierarchies (see Hess, Langreiter \& Timm 2011).

9 Members of the research group were Serhat Karakayali, Vassilis Tsianos, Manuela Bojadzijev, Rutvica Andrijašević und Efthimia Panagiotidis.

$10 \mathrm{I}$ am indebted to this research project, one element of the research and exhibition project I directed in 2009, Crossing Munich, for many of the ideas in this essay on the negative impact of this discourse even at the municipal level.

11 "It is necessary that the serious criminal offence of trafficking in human beings be addressed not only through individual action by each Member State, but by a comprehensive approach in which the definition of constituent elements of criminal law common to all Member States, including effective, proportionate and dissuasive sanctions, forms an integral part" (preamble, paragraph 7).

12 I call the IOM an "all-around agency" since the IOM is involved in almost all facets of migration policy and practice from voluntary repatriation to public relation campaigns, disaster response, capacity-building measures such as building immigrant detention centres, and restitution payments for former slave labourers (see Georgi 2010).

13 Folmer and Rabe write: "The second report by the UN Office on Drugs and Crime (UNODC) compiles world data on human trafficking from criminal prosecution authorities, but also states that more can be learned from this about the activities of the criminal prosecution authorities than about the real numbers of crimes and victims" (2009: 20).

14 Analogous to the three Cs are the three Ds of men's migration: dirty, dangerous, and dull (see Favell 2009).

15 Alongside border controls outside national borders, there are now also various "borders" which have been drawn within countries as a result of the Schengen 
Agreement. For example, train stations and expressways are now considered "border areas" in which border police may control identities at any time. For migrants, this multiplication of borders means they can be confronted with a "border control" at any time.

16 German labour law still has a priority system according to which an open position must be filled first by a "German", second by an "EU foreigner" if no qualified German can be found and third, only if again no one is found, by a so-called third country party.

17 One catalyst was the crises of the national system of asylum in the late 1980s when legal immigration became more difficult, and more and more migrants used asylum as an immigration loophole, "overstretching" the right to asylum, as Sadako Ogata saw it, then director of the UNHCR (see Ogata 1997). Leading functionaries and bureaucrats demanded the Europeanization of migration policy and a shift towards "migration management". The IOM, which pushes global migration management, played a central role in this policy shift (see Ghosh 1997; Hess 2010).

18 Phillip Ratfisch and Stephan Scheel (2010) identified a similar mechanism within the context of asylum policy and practice. In this case too, the rhetoric of protection allows the UNHCR not only to speak for refugees, but also allows them to selectively weed out refugees in need of protection from the vast mass of irregular migrants.

19 This conflation of "feminist" and "national" is inspired by Encarnacion Gutierrez Rodriguez's thoughts on Jasbir Puar's ideas about the "biopolitical logic of homonational discourses" in the context of the US war against terror (Rodriguez 2011: 95).

20 In this case, it is the "Muslim man" in particular who is presented as the homophobic, fundamental "other".

21 Whereby here too it is the "Muslim man" who is portrayed as patriarchal and violent.

\section{References}

Anderson, Bridget 2009: What is in a name? Immigration Controls and Subjectivities: The Case of Au Pairs and Domestic Worker Visa Holders in the UK. Subjectivity 29, 407-424.

Andrijašević, Rutvica 2005: Schöne tote Körper: Gender, Migration und Repräsentation in Kampagnen gegen Menschenhandel. In: www.policy.hu/andrijasevic/IOM.html. Accessed January 15, 2013.

Andrijašević, Rutvica 2009: Sex on the Move: Gender, Subjectivity and Differential Inclusion. Subjectivity 29, 389 406.

Andrijašević, Rutvica 2010: Migration, Agency and Citizenship in Sex Trafficking. London: Palgrave Macmillan.

Anthias, Floya \& Gabriela Lazaridis (eds.) 2000: Gender and
Migration in Southern Europe: Women on the Move. Oxford \& New York: Berg.

Bahl, Eva, Marina Ginal \& Bernd Kasparek et al. 2009: Tulbeck 12: Das Münchner Migrationsregime. In: Natalie Bayer, Andrea Engl \& Sabine Hess et al. (eds.), Crossing Munich: Beiträge zur Migration aus Kunst, Wissenschaft und Aktivismus. Munich: Verlag Silke Schreiber.

Bahl, Eva, Marina Ginal \& Sabine Hess 2010: Feministische Kritik am europäischen Grenzregime: Zur Funktionalität des Anti-Trafficking-Diskurses. In: Stefanie Kron, Martha Zapata \& Birgit zur Nieden (eds.), Diasporische Bewegungen im transatlantischen Raum. Berlin: Verlag Walter Frey.

Birsl, Ursula 2005: Migration und Migrationspolitik im Prozess der europäischen Integration? Opladen: Campus Verlag.

Böker, Marion 2004: Die counter-trafficking-Politik der IOM. Eine kritische Sicht aus NGO-Perspektive. In: Forschungsgesellschaft Flucht und Migration (ed.), Stop IOM! Globale Bewegung gegen Migrationsmanagement. www.ffm-berlin.de/iomstopdt.pdf. Accessed February 13, 2012.

von Braun, Christina \& Bettina Mathes 2007: Verschleierte Wirklichkeit: Die Frau, der Islam und der Westen. Berlin: Aufbau Verlag.

Commission of the European Union 1996: Commission communication of 20 November 1996 to the Council and the European Parliament on trafficking in women for the purpose of sexual exploitation. http://europa.eu/legislation_summaries/employment_and_social_policy/equality_between_men_and_women/133095_en.htm. Accessed May 21, 2012.

Commission of the European Union 1998: Commission communication of 9 December 1998 to the Council and the European Parliament proposing further action in the fight against trafficking in women. http://europa.eu/ legislation_summaries/employment_and_social_policy/ equality_between_men_and_women/133096_en.htm. Accessed May 21, 2012.

Commission of the European Union 2000: Decision No 293/2000/EC of the European Parliament and of the Council of 24 January 2000 adopting a programme of Community action (the Daphne programme) (2000 to 2003) on preventive measures to fight violence against children, young persons and women. In: Official Journal of the European Communities L 34 from February 09, 2000. http://europa.eu/legislation_summaries/human_rights/ fundamental_rights_within_european_union/133062_ en.htm. Accessed May 21, 2012.

Commission of the European Union 2001: White Paper on European Governance. http://eur-lex.europa.eu/LexUriServ/ site/en/com/2001/com2001_0428en01.pdf. Accessed May 24, 2012.

Commission of the European Union 2007: Applying the global approach to Migration to the Eastern and South- 
Eastern regions neighbouring the European Union, Co(2007)247. http://eur-lex.europa.eu/LexUriServ/LexUriServ.do?uri=CELEX:52007DC0247:EN:NOT.Accessed May 24, 2012.

Council of the European Union 2002: Council Framework Decision of 19 July 2002 on combating trafficking in human beings, 2002/629/JI. In: Official Journal of the European Communities L 203/1 from August 1, 2002. http:// eur-lex.europa.eu/LexUriServ/LexUriServ.do?uri=OJ: L:2002:203:0001:0004:EN:PDF. Accessed February 13, 2012.

Doezema, Jo 2002: The Ideology of Trafficking. Paper presented at Work Conference "Human Trafficking" on November 15, 2002. www.nswp.org/sites/nswp.org/files/ DOEZEMA-IDEOLOGY.pdf. Accessed May 30, 2012.

Düvell, Frank 2002: Die Globalisierung des Migrationsregimes. Berlin, Hamburg \& Göttingen: Assoziation A.

Erdem, Esra 2009: In der Falle einer Politik des Ressentiments. In: Sabine Hess, Jana Binder \& Johannes Moser (eds.), No integration?! Bielefeld: Transcript Verlag.

Erel, Umut \& Eleonore Kofman 2003: Professional Female Immigration in Post-War Europe: Counteracting an Historical Amnesia. In: Rainer Ohliger, Karen Schönwälder \& Triadafilos Triadafilopoulos (eds.), European Encounters: Migrants, Migration and European Societies since 1945. Aldershot: Ashgate Publishing Ltd.

Essed, Philomena 1995: Gender, Migration and Cross-Ethnic Coalition Building. In: Helma Lutz, Ann Phoenix \& Nira Yuval-Davis (eds.), Crossfires: Nationalism, Racism and Gender in Europe. London: Pluto Press.

Favell, Adrian 2009: Immigration, Migration and Free Movement in the Making of Europe. In: Jeffrey T. Checkel \& Peter J. Katzenstein (eds.), European Identity. Cambridge: Cambridge University Press.

Ferguson, James \& Akhil Gupta 2005: Spatializing States: Toward an Ethnography of Neoliberal Governmentality. In: Jonathan Xavier Inda (ed.), Anthropologies of Modernity. Malden: Blackwell Publishing.

Folmer, P. \& H. Rabe 2009: Human Trafficking in Germany. Berlin: German Institute for Human Rights. http://www. institut-fuer-menschenrechte.de/uploads/tx_commerce/ study_human_trafficking_in_germany.pdf. Accessed May 23, 2012.

Foucault, Michel 1980: The Confessions of the Flesh. In: Michel Foucault, Power/Knowledge: Selected Interviews and Other Writings. 1972-1977. Trans. Colin Gordon. New York: Pantheon Books.

Geiger, Martin \& Antoine Pécoud (eds.) 2010: The Politics of International Migration Management. London: Palgrave Macmillan.

Georgi, Fabian 2007: Migrationsmanagement in Europa: Eine kritische Studie am Beispiel des Centers for Migration Policy Development. Saarbrücken: VDN-Verlag.

Georgi, Fabian 2010: Internationale Organisation für Mi- gration. In: Sabine Hess \& Bernd Kasparek (eds.), Grenzregime: Diskurse, Praktiken, Institutionen in Europa. Berlin: Association A.

Ghosh, Bimal 1997: Bevölkerungsbewegungen: Die Suche nach einem neuen internationalen Regime. In: Steffen Angenendt (ed.), Migration und Flucht. Munich: Oldenbourg Verlag.

Guiraudon, Virginie 2001: De-Nationalising Control: Analysing State Responses to Restraints on Migration Control. In: Virginie Guiraudon \& Christian Joppke (eds.), Controlling a New Migration World. London: Routledge.

Gümen, Sedef 1996: Die sozialpolitische Konstruktion "kultureller" Differenzen in der bundesdeutschen Frauenund Migrationsforschung. In: Beiträge zur feministischen Theorie und Praxis: Ent-fremdung. Migration und Dominanzgesellschaft 42, 77-90.

Hahn, Kristina 2007: Umstrittene Strategien gegen Menschenhandel: Kontroverse zwischen NGOs bei den Verhandlungen zum UN Protokoll geht weiter. Femina Politica: Zeitschrift für feministische Politikwissenschaft 1, 105-109.

Hess, Sabine 2005: Globalisierte Hausarbeit: Au-Pair als Migrationsstrategie von Frauen aus Osteuropa. Wiesbaden: VS Verlag für Sozialwissenschaften.

Hess, Sabine 2009: "Man schickt doch nicht eine Ersatzbraut zum Altar": Zur Konfliktualität der neuen Formen des Regierens in und von Europa. In: Gisela Welz \& Annalina Lottermann (eds.), Projekte der Europäisierung: Kulturanthropologische Forschungsperspektiven. Kulturanthropologische Notizen 78, 181-196.

Hess, Sabine 2010: "We are facilitating states": An Ethnographic Analysis of the ICMPD. In: Martin Geiger \& Antoine Pécoud (eds.), The Politics of International Migration Management. London: Palgrave Macmillan.

Hess, Sabine 2011: Caught in Mobility: An Ethnographic Analysis of the Context of Knowledge Production on Migration in Southeast Europe. In: Mechthild Baumann \& Astrid Lorenz (eds.), Crossing and Controlling Borders Immigration Policies and their Impact on Migrants' Journeys. Leverkusen: Opladen, pp. 229-248.

Hess, Sabine \& Serhat Karakayali 2007: New Governance oder: Die imperiale Kunst des Regierens: Asyldiskurs und Menschenrechtsdispositiv im neuen EU-Migrationsmanagement. In: TRANSIT MIGRATION Forschungsgruppe (ed.), Turbulente Ränder: Neue Perspektiven auf Migration an den Rändern Europas. Bielefeld: Transcript Verlag.

Hess, Sabine \& Vassilis Tsianos 2007: Europeanizing transnationalism! Provinzializing Europe! Konturen eines neuen Grenzregimes. In: Transit Migration Forschungsgruppe (ed.), Turbulente Ränder: Neue Perspektiven auf Migration an den Rändern Europas. Bielefeld: Transcript Verlag.

Hess, Sabine, Serhat Karakayali \& Vassilis Tsianos 2009: Transnational Migration: Theory and Method of an Eth- 
nographic Analysis of Border Regimes. In: Sussex Centre for Migration Research. Working Papers No. 55. www. sussex.ac.uk/migration/documents/mwp55.pdf. Accessed May 30, 2012.

Hess, Sabine \& Bernd Kasparek (eds.) 2010: Grenzregime: Diskurse, Praktiken, Institutionen in Europe. Berlin: Association A.

Hess, Sabine, Nicola Langreiter \& Elisabeth Timm (eds.) 2011: Intersektionalität revisited. Bielefeld: Transcript Verlag.

Hochschild, Arlie Russel 1983: The Managed Heart: Commercialization of Human Feeling. Berkeley: University of California Press.

Hummel, Diana 1993: Lohnende Geschäfte: Frauenhandel mit Osteuropäerinnen und der EG-Binnenmarkt. Beiträge zur feministischen Theorie und Praxis: Europa - einig Vaterland 34, 61-67.

ICMPD 2012a: Budapest Process. http://www.icmpd.org/ Budapest-Process.1528.0.html. Accessed February 12, 2012.

ICMPD2012b:MissionStatement.www.icmpd.org/ABOUTUS.1513.0.html. Accessed May 31, 2012.

ICMPD 2012c: The Mediterranean Transit Migration Dialogue. www.icmpd.org/MTM.1558.0.html. Accessed May 31, 2012.

i-Map 2012: www.imap-migration.org/index.php?id=471. Accessed June 5, 2012.

Karakayali, Serhat 2008: Gespenster der Migration. Bielefeld: Transcript Verlag.

Karrer, Christina, Regula Turtschi \& Maritza Le Breton Baumgartner 1996: Entschieden im Abseits: Frauen in der Migration. Zurich: Limmat Verlag.

Keller, Reiner 2008: Michel Foucault. Konstanz: UVK Verlagsgesellschaft mbH.

Kofman, Eleonore \& Rosemary Sales 1998: Migrant Women and Exclusion in Europe. The European Journal of Women's Studies 5:3-4, 381-399.

Lahav, Gallya \& Virginie Guiraudon 2000: Comparative Perspectives on Border Control: Away from the Border and Outside the State. In: Peter Andreas \& Timothy Snyder (eds.), The Wall around the West: State Borders and Immigration Control in North America and Europe. New York \& Oxford: Rowman \& Littlefield.

Lenz, Ramona 2009: "We have to convince them that they are victims". In: Jutta Baccas (ed.), Illegale Migration in Südosteuropa. Unpublished manuscript.

Lindqvist, Beatriz 2007: Migrant Women in Ambiguous Business: Examining Sex Work across National Borders in the Baltic Sea Region. In: Erik Berggren (ed.), Irregular Migration, Informal Labour and Community: A Challenge for Europe. Maastricht: Shaker Publishing.

Lutz, Helma 2007: Vom Weltmarkt in den Privathaushalt. Opladen: Budrich.

Lutz, Helma 2008: Gender in the Migratory Process. Lecture at the Conference on Theories of Migration and Social Change, St. Ann's College, Oxford, July 1-3, 2008.
Marcus, George E. 1995: Ethnography in/of the World System: The Emergence of Multi-Sited Ethnography. Annual Review of Anthropology 24, 95-117.

Mezzadra, Sandro 2009: Bürger und Untertanen: Die postkoloniale Herausforderung der Migration in Europa. In: Sabine Hess \& Jana Binder (eds.), No integration?! Kulturwissenschaftliche Beiträge zu Fragen von Migration und Integration in Europa. Bielefeld: Transcript Verlag.

Migmap 2006: GoverningMigration:AVirtualCartography of European Migration Policies. Map 1: Actors. www.transitmigration.org/migmap/home_map1.html. Accessed May 24, 2012.

Mohanty, Chandra Talpade 1988: Aus westlicher Sicht: Feministische Theorie und koloniale Diskurse. Beiträge zur feministischen Theorie und Praxis: Modernisierung der Ungleichheit-weltweit 23, 149-162.

Morokvasic, Mirjana 1984: "Birds of Passage are also Female”. International Migration Review 18, 890-910.

MTV 2012: EXIT. http://www.mtv.de/article/2009-02-10/ 23010643-mtv-exit-when-will-i-feel-love.html. Accessed February 13, 2012.

Ogata, Sadako 1997: Flüchtlinge und Migranten: Möglichkeiten der Steuerung von Wanderungsbewegungen. In: Steffen Angenendt (ed.), Migration und Flucht. Munich: Bundeszentrale für politische Bildung, pp. 239-247.

Pro Asyl 2008: Neue Recherchen und Dokumente zur Situation von Schutzsuchenden in Griechenland. http://www. proasyl.de/fileadmin/proasyl/fm_redakteure/Asyl_in_Europa/Griechenland/Neue_Recherchen_Griechenland_ Endversion.pdf. Accessed May 31, 2012.

Puar, Jasbir 2007: Terrorist Assemblages: Homonationalism in Queer Times. Durham \& London: Duke University Press.

Ratfisch, Phillip \& Stephan Scheel 2010: Migrationskontrolle durch Flüchtlingsschutz. In: Sabine Hess \& Bernd Kasparek (eds.), Grenzregime: Diskurse, Praktiken, Institutionen in Europa. Berlin: Association A.

Ravenstein, Ernest George 1885: The Laws of Migration. Journal of the Statistical Society of London 48:2, 167-235.

Rodriguez, Encarnacion Gutierrez 2011: Intersektionalität oder: Wie nicht über Rassismus sprechen? In: Sabine Hess, Nicola Langreiter \& Elisabeth Timm (eds.), Intersektionalität revisited. Bielefeld: Transcript Verlag.

Schöning-Kalender, Claudia 1989: Frauenhandel in Deutschland. Bonn: Dietz.

Schwenken, Helen 2006: Rechtlos aber nicht ohne Stimme. Bielefeld: Transcript Verlag.

Shore, Cris \& Susan Wright 1997: Policy: A New Field of Anthropology. In: Cris Shore \& Susan Wright (eds.), Anthropology of Policy. London: Routledge.

Speer, Marc 2010: Die Ukraine als migrantisch genutztes Transitland. In: Sabine Hess \& Bernd Kasparek (eds.), Grenzregime: Diskurse, Praktiken, Institutionen in Europa. Berlin: Association A.

Spivak, Gayatri Chakravorty 1990: The Post-Colonial Critic: 
Interviews, Strategies, Dialogues. Edited by Sarah Harasym. New York \& London: Routledge.

Surtees, Rebecca 2007: Listening to Victims: Experiences of Identification, Return and Assistance in South-Eastern Europe, Vienna: icmpd. www.anti-trafficking.net/251. html?\&tx_icmpd_pi2 [document] $=593 \&$ cHash $=6688569$ e46. Accessed May 31, 2012.

Tsianos, Vassilis 2008: Die Karte Europas und die Ströme der Migration. In: Grundrisse: October 2008. www.linksnet.de/ de/artikel/23757. Accessed May 31, 2012.

Vasta, Ellie 2008: The Paper Market: 'Borrowing' and 'Renting' of Identity Documents. University of Oxford Centre on Migration, Policy and Society, Working Paper No. 61. www.compas.ox.ac.uk/fileadmin/files/Publications/working_papers/WP_2008/WP0861\%20Ellie\%20Vasta.pdf. Accessed May 31, 2012.

UN.GIFT 2007: Joint Conference of the Republic of Turkey, UNODC, Budapest Process and the Organisation of the Black Sea Economic Cooperation (BSEC) on "Trafficking in the Black Sea Region". www.ungift.org/ungift/en/re_ turkey_press_release.html. Accessed February 12, 2012.

UNODC 2004: United Nations Convention against Transnational Organized Crime and the Protocols thereto. www.
unodc.org/documents/treaties/UNTOC/Publications/ TOC\%20Convention/TOCebook-e.pdf. Accessed May 23, 2012.

US Department of State 2012: Office to Monitor and Combat Trafficking in Persons. www.state.gov/j/tip/. Accessed May 24, 2012.

Walters, Wiliam 2002: Mapping Schengenland: Denaturalizing the Border. Environment \& Planning: Society \& Space 20:5, 561-580.

Walters, William 2010: Foucault and Frontiers: Notes on the Birth of the Humanitarian Border. In: Ulrich Bröckling, Susanne Krasmann \& Thomas Lemke (eds.), Governmentality: Current Issues and Future Challenges. London: Routledge.

Sabine Hess is Professor of Cultural Anthropology and European Ethnology at the University of Göttingen. Her most recent book on migration and border-regime research is edited with Bernd Kasparek, Grenzregime: Diskurse, Praktiken, Institutionen in Europa (Border Regimes: Discourses, Practices, Institutions in Europe) (2010/2012).

(shess@uni-goettingen.de) 


\title{
WHO IS AFRAID OF FRANKENSTEIN? Polish Debate on In-Vitro Fertilization
}

\author{
Magdalena Radkowska-Walkowicz
}

\begin{abstract}
The in-vitro fertilization (IVF) technology has been in use in Poland for over 20 years, with success and social approval. However, in 2007 a vehement debate on moral, legal, and economic aspects of applying this technology of assisted procreation broke out. This was related to the gaps in Polish legislation lacking the regulations concerning the IVF, especially concerning the coverage by the public health-care system. Moreover, the Catholic voices demanding prohibition of the IVF had been multiplying and intensifying. The article follows this debate, investigates the discursive strategies employed to oppose IVF, and analyses different positions, especially the argumentation of the opponents, and the narratives by those who struggle with infertility.
\end{abstract}

Keywords: in-vitro fertilization, reproductive rights, the Catholic Church, Poland, Frankenstein

The in-vitro fertilization (IVF) technology has been in use in Poland for over twenty years, with success and social approval. However, at the end of 2007 a vehement debate on moral, legal, and economic aspects of applying this technology of assisted procreation broke out. Then the Minister of Health announced she would launch efforts to finance IVF from the state budget and in that way broke the silence over new reproductive technologies in Poland. This article focuses on the Polish IVF debate. I situate it within a global context, explore its local specificity, and examine its cultural and social parameters and implications. My analysis concentrates on the rhetoric and the discursive strategies used by the main participants as well as the narratives of people struggling with infertility.
I am especially interested in reasons for opposing the use of IVF (apart from the most obvious ones, such as accumulating political capital or obeying the Catholic doctrine), mainly because it is the opponents' voices that are best heard in Polish media, imposing the IVF debate's language and thereby shaping the ways of thinking about assisted reproductive technologies (ART). Furthermore, while many works in social analysis critically examine technological optimism, typically drawing on Foucault's critique of modern biopolitics (see e.g., Franklin \& Ragoné 1998; for critiques of ART see, e.g., Inhorn \& von Balen 2002; Thompson 2002), few anthropological studies have explored voices of disapproval of IVF (e.g., Turney 1998; Throsby 2004: 3-6). 
At this point, it needs to be added that to formulate opinions on ART means to engage in political action. This is especially true in the case of Poland, where feminist voices are weak and reproductive rights are both limited and not respected (Graff 2003). Besides, the IVF debate is part of a larger discussion regarding the influence of the Church on policy-making and social life in Poland.

Although Western, especially North-American, socio-cultural anthropology and feminist critique have long explored the challenges posed by reproductive technologies (e.g., Franklin \& Ragoné 1998; Ginsburg \& Rapp 1995), in Eastern Europe, "the social and cultural meanings and effects of ARTs are heavily understudied" (de Jong \& Tkach 2009b: 15; the problem of ART in Europe is explored, e.g., in these works: Bonaccorso 2004, 2009; de Jong \& Tkach 2009a; Saetnan, Oudshoorn \& Kirejczyk 2000). While one can find works by Polish authors exploring legal and bioethical problems related to IVF, anthropological research on ART practically does not exist in Poland.

In what follows, I offer an anthropological perspective drawing on qualitative methods, primarily discourse analysis. I focus on the largest Polish media: television stations (both public and private), the press (newspapers, weekly and monthly magazines), and the Internet. Drawing from the Internet, I analyse, firstly, journalistic publications, including those published on websites endorsed by the Catholic Church (e.g., opoka.pl, fronda.pl, adonai. $\mathrm{pl}$ ), and secondly, the biggest Polish Internet forums pertaining to infertility, where infertile women tell their life histories and exchange information about their treatments. The main sites are NaszBocian.pl, affiliated with the Polish Association for Treating Infertility and Supporting Adoption, "Nasz Bocian" ('Our Stork'), and Gazeta.pl, which belongs to the largest group of Polish online services. Both boards are open to the public. I am not taking into account ethnographic observations in infertility clinics or interviews with IVF users. Materials of this kind will be gathered in the second part of my research project.

\section{Historical and Legal Context}

Louise Brown, the first "test tube baby", was born in Oldham, Great Britain, in 1978. The procedure was carried out by the doctors of medicine Patrick Steptoe and Robert Edwards, who were awarded the 2010 Nobel Prize in Physiology or Medicine. The first child conceived using this method in Poland was a girl too. She was born on November 12th 1987, owing to the efforts of the team led by Professor Marian Szamatowicz of the Medical University of Białystok. Until October 2012 the child remained anonymous, as is the case with thousands of other children conceived in this way. At that time, after the first Polish IVF,

The media went crazy. (...) Białystok was deluged with letters. One priest would rail from the pulpit about the inhumane practices of the clinic, which, according to him, were even more harmful than drug addiction and drunkenness, and the women would talk of their dreams in which they were cuddling babies. They were begging, writing that their husbands wanted to leave them, and that their hands were reaching out for other people's infants. (Skibniewska 2009)

It is estimated that around 5 million people worldwide have been born thanks to in-vitro fertilization. ${ }^{1}$ In Poland there are currently over 40 clinics, which attain good pregnancy rates on a global comparison. The percentage of IVF children totals approximately 1.5 percent, which is the average for highly developed countries (although in Belgium, Slovenia, Denmark, the Netherlands and Sweden more than 3.0 percent of all babies born were conceived by $\mathrm{ART}^{2}$ ). These are, however, only estimates, for there are no mechanisms of extracorporeal fertilization registration in Poland, and the clinics carrying out these procedures are under no obligation to make the data pertaining to their activities public.

In Poland, ARTs are not regulated by law. Currently, several draft bills have been submitted to the Parliament, ranging from a very restrictive proposal to ban IVF and punish by prison for carrying out IVF to a liberal one holding no limitation on it. 
The draft prepared by Jarosław Gowin (the current Minister of Justice) is the most hotly disputed draft among the legislative proposals. It prohibits the destroying and freezing of human embryos, treating them as human beings, to whom the constitutional protection of dignity applies. Therefore, the procedure cannot result in the production of additional embryos. One is only allowed to produce two of them and they both have to be implanted into a woman's body. This method, however, would only be available to married heterosexual couples where the woman is not older than forty years. Moreover, the draft bans the collection of donated eggs and the setting up of sperm banks. Assisted procreation would not be available to couples with genetic diseases or disabilities. Should such a solution be approved, Poland's regulations of this matter would be the most restrictive in Europe (even more so than the extremely restrictive laws adapted in Italy or Germany). A more open project of the ruling party allows for freezing and producing additional embryos and IVF would be available also for single mothers and unmarried couples. However, both draft projects do not provide state funding for the treatment. Nevertheless in October 2012 Prime Minister Donald Tusk declared that reimbursement for IVF will be made available without a change in law, as part of a Health Ministry three-year programme.

\section{Social Acceptance of IVF and the Catholic Church}

When mapping out attitudes towards IVF in the main Polish media, one can get the distinct impression that the main actors in the debate are politicians and priests. It is rarely that representatives of feminist circles appear in the press or television - as is also the case in other countries (Saetnan, Oudshoorn \& Kirejczyk 2000). But, what may seem more surprising, particularly given the fact that infertility in Europe is strongly medicalized as well (cf. Martin 1987; Unnithan-Kumar 2004), biologists' and physicians' voices too are often ignored in the Polish public debate. The same may be said of the public presence of the infertile couples themselves, who are occasionally quoted in newspaper commen- taries, anonymously or under changed names. This way of defining the main actors reduces the discussion to worldview issues and, effectively, the problem of IVF is debated alongside other socially sensitive questions, such as abortion, which is legal in Poland only when the woman's life or health is in danger, when the pregnancy is the result of a rape, or when the fetus is seriously malformed. In fact, IVF is often described as "refined" abortion (about similarity between IVF and abortion debates in Poland see Chełstowska 2011: 104).

Following the Polish debate on IVF one can get the impression that there are about as many opponents as there are supporters of IVF and that the line of division clearly overlaps with their partisan allegiances or even their adherence to the Catholic Church. However, the majority of Poles support IVF, regardless of their attachment to the Church or the party they vote for. According to the Public Opinion Research Centre's (CBOS) report from September 2012, 79 percent of Poles approve of the use of IVF by married couples that cannot have children, and 60 percent in the case of unmarried partners. 41 percent are against the availability of IVF to single women (while 48 percent support it) and 58 percent would allow the creation of additional embryos. Finally, the majority (79 percent) would want the cost of IVF to be at least partially refunded from the state budget (CBOS 2012). These data are similar to those from previous years. In 1995, the acceptance of IVF in the case of heterosexual couples amounted to 73 percent, in 2003 to 64 percent, and in 2005 it was 76 percent. The CBOS report for 2008 - the year the IVF opponents' media campaign was launched - shows a considerable decrease in the support, estimated at 60 percent (CBOS 2008). Nevertheless, and despite the clear and frequent statements issued by the Church firmly opposing the use of IVF, a year later the support was once again high and on the rise.

One may find it worthwhile to consider the origin of such a broad acceptance of extracorporeal fertilization in the country where, according to declarations, the percentage of Catholics may be as high as 90 percent depending on the study (Borowik 2001: 23) and where the second largest party in the Parlia- 
ment is implicitly endorsed by the majority of Church hierarchs and ordinary priests, who declare their attachment to traditional values, including, of course, Catholic values. Moreover, the Polish Church, while internally divided, speaks unanimously.

One of the reasons that this powerful voice of the Church is not fully taken into account by the Polish society appears to be its moral liberalization in line with European trends. Thus, the Poles' attitudes towards sexual issues (such as premarital sex, nonmonogamous relationships or the use of contraception) are far more lax than the official position of the Church would dictate. In other words, one can observe a strong individualization and privatization of religion; although one can hardly talk about an institutional crisis of the Catholic Church, as is the case in Western Europe, many people reinterpret the dogmas and teachings of the Church according to their own point of view.

Despite the strong opposition of the Church, there are about as many Catholics among the people undergoing IVF programmes as in the whole population of Poland. On the forum of the website Gazeta.pl, a girl nicknamed iwonaczarna writes:

you know, it is so strange, because when you leave that place [the doctor's office, where the IVF procedure was carried out] you know that you have been given something that is already working inside of you. It's certainly fighting to stay there, but it is so small and you can't do anything to help him. When I received the two angels [embryos] I prayed for them to somehow manage. Yesterday was Sunday. I went to church and I cried asking Him to let them stay; He already has enough angels. I think it is the only sign that the closer it gets the more strongly you believe in all this. I know the Church speaks badly of this method, but I went there, for the first time in a very long time, so that even my husband was shocked. I hope He will spare us, I pray.

\section{Family, Love and Laboratory}

Paradoxically, this strong support of IVF is connected to the Poles' attachment to traditional values, especially to the family as a category organizing social life and hierarchy of values. Although new reproductive techniques have transformed common conceptions of kinship, the main symbols of the ideology of affinity in Euro-American culture have remained constant (Ragoné 2004: 342). It is still the birth of a child that turns a couple into a family, and the reason for the decision to use ART is the strong need to have an offspring. Being a childless couple, as many infertile couples would stress, carries a social stigma. A couple is, therefore, ready to use untraditional methods in order to achieve a traditional result: a family comprising a mum, a dad and at least one child. Although, as many researchers point out (e.g., Laqueur 2000), the development of techniques enabling the birth of a child without a sexual act results in the questioning of the previous concepts of the family, the family itself does not need to be questioned. Rather, IVF gets "normalized, naturalized, and contextualized within the narrowest and most traditional definitions of family" (Franklin \& Roberts 2006: 188).

The problem of kinship and the diffusion of the category of the legal, genetic and biological parenthood do not appear in the Polish debate on IVF, including academic discourses. Mainstream media strongly condemn surrogate mothering, which is only discussed in economic-moral categories and almost always critically and sensationally (cf. Radkowska-Walkowicz 2012a). Access to reproductive technologies by gay couples is presented as one example of the kind of degeneration that ART can lead to. The subject of gamete donation or use of sperm banks is also rarely brought up. The debate stops at the level of the IVF procedure itself and the consequences of its use for future embryos.

Thus, the implicit notion of family is never put under discussion. Rather, what underpins the contention are two kinds of sentiments regarding the same ideal of a "full family": on the one hand, the extremely strong cultural need to have it, and, on the other, the fear that IVF would lead to its redefinition. When people who underwent IVF claim it gave them hope for starting a real family, the other side responds by criticizing them for their egoism and 
disregard for the value of marriage. Indeed, the notion marriage has become one of the rudimentary categories cited by the opponents of ART. Archbishop Henryk Hoser stresses the symbolic meaning of the marital act as "two in one body", and argues:

It is only in this light that one can notice how very different the marital act is from the reproductive copulation of animals. A child - conceived as a result of a married life - is perceived as something we were given, something of a blessing. In the process of extracorporeal fertilization, however, a child is "made to order" using a particular technique. (Hoser 2009: 4)

Opponents of IVF set marital love against the vial. Marek Czachorowski from the Catholic University of Lublin admits that "objective facts show that in artificial insemination one does not conceive one's own child out of marital love - in an act expressing it - but out of something else, which does not express the specificity of marital love. At the start of our child's life it is not granted love" (Czachorowski 2008). In this rhetoric love is in the family by definition. It can only happen behind closed bedroom doors, where no one will inspect it, control it, or call it a rape.

On December 28, 2008, on the Holy Family Sunday, the Polish Episcopate issued a letter to the faithful, in which it touched upon the issue of IVF (List pasterski... 2008). The Episcopate pointed out that "God and only God is the Master of Life. Children are His gift to us and not a consumption good”. Bishop Tadeusz Pieronek explicated it even more pointedly: "Couples who resort to IVF prefer buying a child to adopting it. They do not want an adopted child because they want to have a child that would be their own'. It is precisely the logic of the commodity, not the gift" (Pieronek 2009). The fear of commercialization of births and commodification of the sphere of procreation has accompanied research on IVF from its very beginning (cf. Turney 1998). In modern culture, these two ideas - the child and the commodity - are conflicting. The romantic mythology of childhood precludes pecuniary dealings. The lack of acceptance of IVF may thus be explained by the reluctance to link economic calculation to the concept of the family, which, as Collier, Rosaldo and Yanagisako (1992) argue, was built exactly in opposition to market relations. The Catholic Church perceives the role of the family in a similar way. However, one can also point out that in the European culture marriage was for centuries primarily an economic contract, and it is only due to more contemporary idealization that we perceive it in the romantic-spiritual light.

In Poland, IVF is sometimes viewed as a whim of the rich, a mark of class distinction. The lack of a refund policy together with the high costs of IVF contribute to the perception of ART users in economic categories. Couples who turn to infertility treatment clinics for help are accused of being egoistic, buying themselves a child and of taking a shortcut - such opinions are circulated widely despite the fact that IVF programmes involve long, unpleasant preparations, with little chance of success. The same arguments are put forward regarding people who do not have children - some campaigns aimed at promoting demographic growth have suggested that the lack of offspring results from a simple consumer choice.

\section{Negotiating Oppositions}

In their rhetoric, opponents of IVF often refer to oppositions between the commercial and the noncommercial, the public and the private, nature and technology. This kind of argumentation also appears in anthropological texts on reproductive technologies. For example, Franklin notes: "What was once a private act of love, intimacy, and secrecy is now a public act, a commercial transaction, and a professionally managed procedure" (1995: 336). In this very context, too, this way of thinking, especially the opposition between what is private and what is public, becomes problematic. Infertility has been so hard to cope with precisely because it is not a private problem; a child is a kind of social desire, Others' desire.

The private-public opposition is often used by the opponents of IVF - blurring the boundaries between these categories can be a source of fear and resist- 
ance. If, as they claim, due to these new technologies reproduction has left the private sphere and become a public issue, it has moved from the bedroom to the doctor's office, one may ask: What is it now that happens in the bedroom? What has taken the place of reproduction? Is it an empty space, waiting to be filled?

The above-mentioned oppositions are negotiated and rejected by users of IVF, but it does not mean that the anthropologist can simply ignore the commercial aspects of ART, which are stressed by many researchers (see Spar 2006; Strathern 1992). The Polish case, as the Italian before 2004 (see Bonaccorso 2004, 2009; Neresini \& Bimbi 2000), is peculiar, because there is no legislation regulating the use of assisted conception. As a result, private clinics are the main players on the infertility treatment scene and practically they are neither inspected nor audited. Thus, patients who decided on IVF are largely dependent on the treatment offered by the private sector, which dictates conditions of the IVF treatment programme, manages the information on ART, and shapes the ART language. What is interesting, it is not only the highly medicalized language which consolidated the authority of physicians, but also the "common language" used to empathize with clients (Bonaccorso 2004). However, both patients and opponents do employ scientific rhetoric and refer to medical research. In this case, scientific language is used depending on the purposes of particular users; it is a common property that gets appropriated and negotiated.

Couples undergoing IVF tend to abandon the simple worldview built on oppositions, including that between romantic act in the marital bed and technological act in the Petri-Dash. In their narrations, they stress mutual love and care about the fight for a child. It is often the impossibility of conceiving that causes breaks in relationships. They are also capable of talking about the transfer of embryos in romantic categories. Magdalena Muszyńska, member of the Polish Association for Treating Infertility and Supporting Adoption, "Nasz Bocian", who had IVF, said in the Polish Parliament: "The moment of the transfer of embryos is one of the most beautiful mo- ments in the life of a woman or a couple. It is then, at that moment, that our future, potential children are given to us, so that they could feel at home in my belly for the next 9 months" (2009: 27). Therefore, undergoing IVF procedure is not a transgressive activity. Here, the crossing of the line only serves to enter a safe, well-known path of narration, in line with the reigning models. In order to achieve that, one sacrifices a lot, including one's relationship with the Catholic Church, which for many people is painful.

According to opponents of IVF, all the planned actions aimed at infertility, also those supported by the Church, are only an addition to God's plan. The gift - not a commodity - will come when one does not expect it. IVF, with its fastidiousness, is at variance with the miraculous work of numbers. The whole preparatory protocol, from the puncture to the transfer of the fertilized egg, is described to the patients in detail - it involves strictly dosed portions of appropriate medicines, and a close monitoring of the cycle. A scientific description encapsulates what has, until this point, carried an aura of mystery. The oppositions of control and spontaneity, technology and mystery, or gift and commodity have a long tradition both in common thought and in the scientific worldview. Their roots lie in the old division of nature and culture. It is, however, such technologies as "in vitro" that show that today this opposition has lost its force and, while it is still used as a rhetorical tool, it is not sufficient for the elucidation of a complex social phenomenon. The analysis of Internet message boards relating to infertility demonstrates it well.

There is a tendency on many of them, not only in Polish Internet forums, to describe their participants in reference to their fight against infertility. One can very often find such a description in the signatures of participants of Internet conversations. The list of female participants, who after long efforts finally gave birth to a child, is as follows (www.nasz-bocian.pl):

JULI01 - I ICSI, crio 2 embr. blast. B i $<8$ B (Iw:E600, P-22, bHCG<1; IIw:P-41), 3 angels [i][i][i] and son Kubuś, DOB 25.05.08

kumkwak - I ICSI 2 blast. B (Iw:E-2605, P-56, 
bHCG-2.5; IIw:E-1837, P-72.8, bHCG 27.2; IIIw:E-4295, P-133, bHCG-237; IVw:E-3952, P-122, bHCG 3393) twins! Agatka and Ada, DOB 24.06.08

carmen81 $4 \mathrm{Y}$ efforts, weak little soldiers, jumping FSH, 20081 ICSI, 1 crio - , herbal 3, my natural miracle 16.04 I've seen 2 lines, 19.04 HCG 177, 21.04. HCG 489, $14.0512 \mathrm{~mm}$ with a little beating heart malgosia1978 3x IUI unsuccessful, PCO, I IVF 04.2008 6w-I usg 2 beans, 8w - 1 angel, 11w II angel, I 2009 IVF unsuccessful, waiting for crio since February 2009 herbal 3, beta 20.04.2009 - 4492 MIRACLE!!!!! Allow him to stay

What seems to be an extremely technical language is shot through with elements having very little in common with it. There are angels (referring to a child who died before being born), a miracle, a " $12 \mathrm{~mm}$ with a little beating heart". They neutralize the technical description. The final stage is a diminutive name, a child, a human being. In descriptions that do not end in a name, there is a potential; it legitimizes the actions one takes. These descriptions encapsulate almost everything the given person has gone through in her fight against infertility. In this extremely formalized way, women legitimize their participation in the infertility community and present their biographies of reproductive medical interventions, which have become a significant part of their self-identity narratives. This kind of narrative strategy does not mean that women and their children (potential or real) are reduced to mathematical and medical symbols and dehumanized, or de-individualized. In this case, medical technology gives hope that series of symbols will turn into a child's name (on the use of discursive strategies by couples who have had unsuccessful IVF, see Throsby 2004). Thus, it is not a process of disembodiment, as one could suppose. "Self", defined in this way, becomes indeed a bodily phenomenon - open and ready for technological interventions. IVF does not separate from the body, which is subject to wanton nature or, as one woman wrote on the Internet forum, cruel statistics: a body, which is socially contextualized and controlled. Rather, it allows for the body to become rediscovered, re-experienced and, to some degree, controlled. These women are not passive victims, cultural dupes, as early feminists indicated (see van Balen \& Inhorn 2002: 15, Thompson 2002, 2005: 55-75). They actively engage with technology. Thus, medical intervention need not be perceived as oppressive technology or even as "giving nature a helping hand", but it might, instead, be understood as an ally in the unequal fight with nature.

Nevertheless, I agree with Monica Bonaccorso's suggestion:

Technological newness in the making of babies is used to stress the inefficiency of a body, which is not simply unreproductive, but often unwilling to welcome/receive technology. The emphasis on the bodies of couples is extreme. It is phenomenal the way in which, from being an intervention that helps couples, technologies of procreation turn into interventions to be aided by couples. Technology thus stands, at once, for both aid and its reverse, progression and arrest. (2004: 90)

Many couples treat the IVF procedure as an element in a certain technical puzzle. However, one can also come across quite other sentiments: "After the puncture under a short anaesthetics I was given breakfast and taken care of wonderfully, and the transfer itself was such a mystical experience (my husband was sitting next to me) that it was even more mystical than the last attempts under a duvet, using natural methods" (kolebeczka, forum Niepłodność [Infertility], Gazeta.pl). Another description shows even more convincingly that the language of technology does not have to be at odds with the language of emotions:

I have just returned from Szczecin and, 3 days after the puncture, I have two beautiful 10A1 and 6A1 little embryos and one embryo (just for the purpose of competition, so that the good two ones do not get lazy with the division) that will not become 3B1 pregnancy. I cannot look at them enough!!!! Now, I can only wait and hope at least one of them stays with me, which is what I wish you from the bottom of my heart. (luna67, forum Niepłodność, Gazeta.pl) 
Mystery can thus stealthily enter the laboratory, appear among the vials, on the glass, in the presence of a white-coat-wearing doctor. And the embryos, labelled with letter-numerical code, can be treated as the wished-for, potential children.

On the one hand, infertile women indicate the emancipatory potential of technology and the usefulness of this kind of language in the process of creating women's self-identities and biographies. On the other, one can see the process of normalization of technology. That process is well described in the research literature (de Jong \& Tkach 2009a; Franklin \& Roberts 2006: 175, 223-224; Thompson 2005; Throsby 2004; Cussins 1998). Thompson (2005) and de Jong (2009) are right linking this process to practices of naturalization, statistification and routinization. It is noticeable in the Polish debate on IVF, too. But one can also observe a reverse practice: describing IVF as the process inconsistent with the nature, biology and social order. The Episcopate is clear about it: "This method is contrary to God's law and human nature" (Komunikat z 352... 2010).

Criminalization of IVF is the common discursive strategy employed in Poland to condemn the use of IVF. For instance, Archbishop Józef Michalik states: "The Killing of an innocent man is a crime and sometimes cruelty and it can never be justified. Both abortion and the elimination of a conceived life in a test-tube is a murder, for a man starts to exists from the moment when two cells: male and female, fuse" (Michalik 2009: 2). The patients of infertility treatment clinics tend to justify their decision by claiming that:

None of us, people who are infertile, would permit such wickedness as the discarding and destroying of embryos to happen. It is also worth noticing that despite the lack of legal regulations, no one would commit such an evil deed and hurt the embryos. It is true that some of them die, but it happens in nature, too. Does it mean that $99 \%$ of women are murderers, and serial ones, at that? (Szczerba 2009: 13)

The well-known argument from the discussion on abortion that claims life already begins at the moment of fertilization is countered by the other party with two kinds of arguments. The first one is connected to the naturalization strategy and points out that when fertilization takes place in a woman's body, many embryos also die even before they nestle in the uterus. The second kind of argumentation underlines that most embryos produced artificially will be given their chance, they will be transferred to the woman's organism, and therefore is not, in fact, based on another definition of the beginning of life than the Catholic definition. Hence, there is no simple opposition between religious and modern (scientific) ideas of the foetal/maternal relation. The Catholic view of the beginning of life encounters the contemporary, modern view, connected with the development of new medical technologies, destabilizing the boundary between mother and foetus. As Susan Squier notes, "the fetus inside is increasingly treated as if it were already outside, the rightful subject of medical, social and legal intervention" (1999: 102).

Women on Internet forums relating to infertility almost always refer to the frozen embryos as their own potential children that will be implanted into a uterus, or - although one can come across such declarations less frequently - put up for adoption. Although the couples are not indifferent to the fate of the embryos, they realize that only some of them have a chance of becoming a child: "there is no such thing as the groan of abandoned embryos (...) there are no hecatombs, mass murders, and we are talking about a phenomenon where we fight against the SCARCITY, and not the excess. (...) People line up in a queue to adopt those supposedly 'unwanted embryos"' (Krawczak 2010).

It is worthwhile to stress the category of nature which appears frequently in both sides' argumentations and which still turns out to be a powerful factor legitimizing moral decisions and opinions of both parties of the dispute. According to users of reproductive technologies, IVF supports the work of nature that today is imperfect - it is on its behalf that they fend off the effects of civilization, which causes infertility. According to the IVF opponents, it acts 
against nature and may ultimately lead to the degeneration of our species.

The opposition between nature and culture and, in particular, its interpretational-explanatory powers, still carries considerable weight. It is the modern culture's reference to biology, to the gene as the basis of human identity that makes ART, and especially IVF or surrogate mothering, an increasingly popular way of "acquiring" children by infertile couples as an alternative to adoption. "Our" child means a child who will have our genes (or at least the genes of one of the parents). New reproductive technologies change ideas of kinship, as has been observed by many researchers, and simultaneously reinforce the biological, genetic notion of relatedness (e.g., Ragoné 2004; Edwards et al. 1993). The modern definition of an individual being a bundle of genetic information (cf. Le Breton 2004; Rabinow 1996) serves to legitimize ART methods also in Poland.

\section{Heritage of Frankenstein}

Although one of the dividing lines in the Polish debate over IVF is determined by attitudes towards science, it would be false to claim that on one side of the debate there are only supporters of the unrestrained development of science, and its staunch opponents on the other. It is true that the modern compulsion to constantly develop, in the Faustian version, is very often criticized by opponents of IVF. They point to the dangers of constant development, invoking the unambiguous persona of doctor Frankenstein, who paid for the attempt to manipulate the human body and nature with his life and the life of his family. Frankenstein, as a figure embodying the fear of the excessive interference of science and technology in human life is still surprisingly topical. "What is the literary figure of Frankenstein, a creature brought to life against nature, if not a prototype of in vitro?" asked one of the important actors in the Polish political scene, the Catholic bishop, Tadeusz Pieronek (2009).

The fact that a test-tube baby is happy and normal - in contrary to Frankenstein's monster - seems to be the scandal. As Jon Turney (1998) writes, the birth of Louise Brown was so shocking precisely because she was a normal child. The crossing of the boundary between nature and technology, the fact that technology entered the area of reproduction, which until now has been a taboo subject, associated with mystery, evokes fears and creates revenge-seeking monsters (cf. Radkowska-Walkowicz 2012b). And monsters have no families. Artificial lives, in this discourse, should be lonely and miserable. "We are well familiar with the experiences of therapists who observed that children conceived by means of IVF have the features characteristic of people who escaped death" - says Beata Rusiecka, a psychologist. There is, however, no research or accounts of the interested parties to support her words.

Such a person is racked with intense guilt, asking himself questions like: why do I live, do I have the right to live? Similar experiences are characteristic of people whose siblings were aborted (...) Similarly, children conceived thanks to IVF, because of the fact that in the embryonic stage they were selected by a doctor from among the other children, feel deeply insecure as to their right to live. (...) They give the impression that they are not at all connected to their parents. They are aware that those are their parents, but it seems they do not emotionally experience the ties with them, as if they were incapable of establishing a psychological contact with them and had a deep-seated fear of their parents. The parents, too, have difficulties establishing a warm, spontaneous, spiritual contact with their children. (Rusiecka, Nasz Dziennik, cited for: http://adonai.pl/nieplodnosc/?id=90)

Loneliness was the punishment of the monster and Frankenstein remained lonely. In this rhetoric, also test-tube babies are lonely. The ghost of doctor Frankenstein has been haunting us for almost 200 years and, it seems, it has no intention of stopping. However, science is not criticized as a whole. Today, it becomes - next to nature - a very important legitimizing category, because in modern society, especially, scientific and medical language is able to influence cultural meanings (an ability widely described in anthropological literature, see e.g. chap- 
ters by Bonaccorso, Stones and Donner in UnnithanKumar [ed.] 2004). Thus, in their argumentation relating to the issues of reproduction, the representatives of the Catholic Church increasingly often cite scientific research and gladly use the language generated by the world of science. Therefore, when they warn us, in line with the Church doctrine, against the use of contraceptives, they refer to research that is supposed to show that hormonal methods are harmful to our health, and the mechanical or chemical ones ineffective. The arguments put forward in the debate over the beginning of life, too, are based on such notions as DNA, the gene, gamete fusion, etc.

In the statement issued by the bioethical conference of the Polish Episcopate one can read:

One of the frequently advanced views is that an embryo is not a human being. Such opinions have no scientific foundation and are the expression of an ideology that denies human beings their right to life from conception. The truth that our life begins at the moment of conception is not based on religious stipulations, but is a rational stance resulting from the current scientific knowledge. (...) The opinion of the Church is also based on premises of the biological and medical nature. IVF procedures are extremely dangerous to the mother's health (...) A hormone stimulation therapy $(. .$.$) can lead to a liver function disorder,$ the development of cancer or venous or arterial thrombosis. (...) Research carried out in the USA and Australia, where the IVF methods have been used longer than in Poland, show that children conceived in an artificial way suffer three times more often from congenital defects, complications and genetic diseases. We cite these arguments to show that the teaching of the Church (...) is corroborated by the results of scientific research. (Oświadczenie Zespołu... 2010) ${ }^{3}$

Thus, the Church frequently refers to medicine. Esther Peperkamp points out this practice in relation to sexual education and "natural family planning" in the Polish Catholic youth movement. She claims that defining the modern body as a secularized body is false, as it "completely ignores the changes that have taken place within Christian traditions themselves" (Peperkamp 2008: 132). Religion has not simply been replaced by modern medicine; rather, the latter "provides the technological means to practice a virtuous life, although it does so with unintended effects, transforming the face of religion and religious authority" (2008: 133).

\section{Gender Biases in IVF Debate}

This trend is well exemplified by NaProTechnology (Natural Procreative Technology), the infertility treatment method in accord with the teachings of the Catholic Church and promoted as an alternative to IVF. It was designed 30 years ago by the American physician Thomas W. Hilgers, the founder and director of the Pope Paul VI Institute in Omaha, Nebraska. He and his supporters claim that this method is very effective and achieves higher pregnancy rates than IVF. It is, www.naprotechnology.com says, "a new women's health science that monitors and maintains a woman's reproductive and gynecological health". It is, above all, based on the Creighton Model Fertility Care System - the observation of the woman's fertility cycle - conducted by trainers who do not need to have medical education, but it does not exclude medical and surgical treatments (as laparoscopy or surgical removal of endometriosis).

NaProTechnology found extremely favourable conditions in Poland. Today, one can both read and hear about it in important Polish media, including the public ones; the method has also been debated in the Polish Parliament. Both on discussion forums and during other discussions, women who underwent IVF procedures are usually sceptical of NaProTechnology, claiming that it has nothing new to offer apart from the diagnostics focusing mainly on the observation of the fertility cycle each of them underwent during the many years of fighting for a child.

One can notice that it is an entry onto the ground of hard science and an attempt to defeat Western biomedicine by "borrowing" from its achievements, terms, etc. Science is here understood as a common, universal good that has so far not always been put 
to good use. It needs to be taken from the hands of doctor Frankenstein and show its humanistic (Catholic) character. Implied here is, therefore, a criticism of biomedicine, perceived as harmful to a woman. NaProTechnology could thus seem close to early feminist critiques, which drew attention to patriarchy and technocracy ingrained in biomedicine and to the reduction of the woman's role to that of an object in the game of men's technological fantasies (e.g., Corea 1985; Stanworth 1987). ${ }^{4}$ However, when one looks at NaProTechnology more closely, it turns out that it is a proposition that strengthens traditional gender imagery. For example, the motto of one website promoting this method is: "Unleashing the Power in a Woman's Cycle." It draws a direct connection between the vitality of the family and the woman's body. However, statistics pertaining to infertility unequivocally show that today, for at least half of the couples, infertility is related to a problem on the part of the man. Although the advocates of NaProTechnology seem to notice the problem of men's infertility, they claim that the success of infertility treatment still critically depends on the observation of the woman's cycle, or on such surgical procedures as restoration of the patency of the oviducts (thus, still directed at the woman's body). Asked whether NaProTechnology cures men's infertility, Hilgers answers: "If, in line with its indications, we get to know the woman's cycle and determine the fertile period, then, even if the sperm is of low quality, we can increase the probability of impregnation by 35\%" (2009: 14). It is, then, the woman that is responsible for the lack of offspring and supposed to create favourable conditions for the child to appear in the domestic hearth. Moreover, the woman is blamed for her infertility. According to the IVF opponents, lack of offspring is a result of the use of hormonal contraception, early age of sexual initiation and delay in starting a family, and even wearing short skirts. In short: the modern woman conducts herself badly and the punishment for this $\sin$ is childlessness.

As van Balen and Inhorn note: "women worldwide appear to bear the major burden of infertility, in terms of blame for the reproductive failing; personal anxiety, frustration, grief, and fear; marital duress, dissolution, and abandonment; social stigma and community ostracism" (2002: 7). Being a mother, now or in the future, is a strong element of the self-identity narrative of the vast majority of women not only in Euro-American culture; when infertility disrupts the plot, women very often feel helpless and confused (Kirkman 2008: 243; on male stigma related to infertility, see Becker 2000: 44-49; Thompson 2005: 128).

What seems to be disturbing for the opponents of IVF is the man's participation in infertility diagnosis. In the Catholic weekly magazine Niedziela (with circulation about 150,000) one reads: "In order to obtain the man's genetic material, the act of masturbation is necessary. This should be enough to discard this method of reproduction" (Konik-Korn 2008: 25). Reading this kind of statement one can get the impression that the old bette-noire of the moralists resurfaces once again. Indeed, the authors of NaProTechnology.com argue that the standard medical evaluation of a man's infertility is "dehumanizing and humiliating", because men are "placed in a washroom with pornographic literature and asked to masturbate, [while] (...) the seminal fluid can be collected with an act of intercourse, at home, in a way which is not contraceptive". By masturbating in a clinic a man not only enters the path of sin, but also degrades himself as a man. Androcentric sensitivity cannot stand the way the material for IVF is obtained. What should stay inside the body flows out of it and is then given to a laboratory technician for analysis. Maybe masculinity, unlike femininity in this rhetoric, is not to be the subject of discussion and generally should not be evaluated catalogued, and verified?

Today, it is typically still women that are blamed for the inability to conceive. The persistent stereotype of a strong man with strong sperm (often referred to as "soldiers" or "the army") makes many Polish men reluctant to undergo tests. Infertility treatment remains the domain of women. It is they who are the participants of discussion forums on infertility (where they often complain about their partners' lack of commitment), seek solutions to 
the problem, and encourage their husbands and partners to have semen analyses. On the one hand, therefore, infertility treatment illustrates traditional family relations, where the woman is responsible for reproduction and supposed to create domestic hearth. On the other hand, in-vitro fertilization constitutes a space of women's activity and agency. The fact that IVF procedures are not refunded and the idea of a partial or total ban of IVF may thus be perceived as denying women a possibility to be rational, moral actors, who make their own decisions concerning reproduction (on women's agency in the context of reproductive technologies see UnnithanKumar 2004).

Urszula Dudziak from the Catholic University of Lublin asks: "Can a woman be truly happy, when she is treated as a stud mare?" (2008). "What right does the laboratory technician-inseminator have to be given the privilege that should be her husband's in the context of the act of a complete union?", asks psychologist Maria Klepacka-Środoń(2008). Maciej Barczentewicz, gynaecologist and president of the Foundation of John Paul II Institute for Marital Infertility Treatment, adds: "A technician replaces the marriage and God in giving life" (2008). May it be that what is so outraging here is the fact that a technician takes the man's right to the woman? When opponents of IVF claim that it deprives women of their dignity and causes them to be treated as stud mares, and when they write about the pain and serious threats to health (such as overstimulation), they make women the victims of the bad, androcentric biomedicine, oppressive to the female body. The example of Poland proves wrong the view that sees women simply as victims of technology. Today, women fight for their right to have access to state-of-the-art medical technologies, which, among other things, allow them to avoid suffering. Presenting women as victims of evil technology, or using the language of the prolife movement and the "civilization of death" is also a way of depriving them of a chance to voice their opinion. Voices of infertile couples are rarely heard in the Polish traditional media. Somebody always speaks on their behalf. The victims are no longer the important social actors and have no right to a rational voice.

However, we may also note that power is already ingrained in the very compulsion to be a mother, which drives a woman to surrender to technology. It is not the woman's choice, but rather a restriction, a means to subjugate her; it has risen to the point of absurd. For the very desire to be a mother can be perceived as a desire of the current discourses producing norms of motherhood which bind women to their identity as mothers and offer specific and ever more technologically perfect methods of dealing with the problem of infertility, at once restricting the ground for new ways of defining themselves outside of motherhood (cf. Sawicki 1999; on feminist studies on ART see McNeil 2007, especially part II). Franklin and Roberts note: "The possibility that conception can be achieved through IVF (...) produces $a$ new form of social responsibility as well as new choices" (2006: 189). Moreover, a result of this process is "an intensification of women's investment in procreation, realized in the regimented orientation and surveillance of her body for this purpose" (McNeil 2007: 86). In this context, Jane Sawicki writes about "new norms of health and responsibility in motherhood" (1991: 84) and McNeil designate it as "an extension of maternal responsibility" (2007: 87).

\section{Conclusion}

Discussions on IVF, as Turney (1998) rightly indicates, started before the birth of Louise Brown. One might suppose that after all arguments both in favour and against IVF have been advanced, IVF will be silently accepted as just another technology that appeared in our lives and, similarly to what happened to many other achievements in medicine, it will become invisible. However, debates which time and again break out with different strength in different countries, along with the powerful voice of the Catholic Church on this matter, show that this issue is neither straightforward nor closed. Poland, where one can watch the IVF debate go on, is not an exception. Such discussions take place in other countries as well and they very often include similar argumentations. At the same time, we deal with their local 
peculiarities visible, for instance, in different legal solutions adopted in particular countries: from very liberal in Great Britain, Israel or the Scandinavian countries, to restrictive ones in Germany, Italy, Austria or several US states. As I am writing these words it is still difficult to predict the fate of the Polish bioethical act. The Polish debate is similar to the one that took place in Italy, a fact related to the specific legal situation in both countries and their Catholic character. On the other hand, as Bonaccorso states, the Catholic framework "cannot be taken too much for granted" (2009: 1), and it seems reasonable to assume that in Poland religious beliefs do not have a determining influence on the negotiation and legitimization of decisions regarding medical intervention. Nevertheless, the Catholic Church does have a prominent role in politics and society and is influential in constructing the meanings assigned to reproduction. It seems that the Church is interested in sex, family and reproduction more than in other aspects of human life and that, de facto, it is interested in controlling women. Above all, this control occurs by means of language (see Graff 2001, 2003). The question is, can its discursive power and privileged position in the public debate change the popular attitude towards IVF?

The Catholic Church is undoubtedly the main actor in IVF debate in Polish mainstream media (the representatives of other Churches are not asked to take a stance on the issue, and their opinion is less radical). At the same time, however, public acceptance of reproductive technologies is very high. The voices of scientists or doctors are, in fact, scarce although they have much influence on the infertile couples' decisions and ways of thinking about the treatment. People who decided to use IVF, rarely asked about their opinion by the mainstream media, discuss their views on Internet forums. But Internet, as Jill Allison (2011) argues convincingly in the context of the Irish IVF debate, rather than creating public discourse, reproduces silence and isolation.

Seemingly, Polish debate on IVF is marked by an oppositional way of thinking: on the one hand scientific, modern, and technical, and on the other religious, moral, and emotional. But these oppositions are negotiated both by the users of the reproductive technology and its opponents. They transcend simple binarism, typical for the language of ART that - as Bonaccorso points out - "always incorporates one thought and its opposite" (2004: 90). Moreover, all participants of the Polish debate use all kinds of argumentation: medical, ideological, ethical, and emotional. Thus, the language of the representatives of the Catholic Church is medicalized, while the language of scientists or physicians is full of emotional references, and women expressing themselves on Internet forums very often demonstrate expert knowledge.

What is interesting about the Polish debate on IVF is the strongly medicalized language of the Catholic activists. Moreover, the Catholic view is often close to the modern, scientific one. Simultaneously, the language of the debate remains full of moral and religious references. Thus, in churches, people pray for "IVF victims" and Jarosław Gowin, who endorses the restrictive draft of the bioethical act, claims that he can "almost hear the scream of despair of those tens of thousands of frozen embryos, feel their distress" (2009).

But it is not only frozen embryos that scream in this debate - one may point out the outcry of Catholic activists about genocide allegedly going on in IVF laboratories. It seems, however, that, more than the screams, it is silences and concealments that are crucial in the IVF discourse.

The silence about infertility is "heard" as a resounding confirmation of fertility as the norm. Maintaining silence means that infertility is rarely mobilized to challenge the naturalization of gendered social expectations and heteronormative values. Silence obscures the fact that fertility is not universal and makes virtually impossible any dialectic move toward a denaturalization of fertility and motherhood. (Allison 2011: 6)

These silences are mostly connected with the social stigma associated with infertility and the hegemonic norms of motherhood. However, the silence is not only a part of private experience. Polish feminists 
remain silent about negative sides of ART and its reductive foundationalism (Rapp 2001), Polish gays do not talk about their reproductive rights and Polish Catholic activists ignore male infertility and the contemporary need to have a genetic offspring. Fertility clinics also resort to a kind of silence, as they are afraid of changes in the reproductive law. Lurking in the background is the issue of excessive interference of science in the contingency of the birth of a human being and, consequently, the possible dangers to the development of the human species. There is also a scarcity of arguments, shown so well in Andrew Niccol's film Gattaca (1997) - arguments related to genoism and the new social stratifications that may be awaiting us. The Polish debate on IVF focuses on the question of beginnings of life and the analysis of this problem in connection with the fierce debate on the admissibility of abortion. The two IVF discourses one may discern in Polish media portray IVF in opposite terms: one sees it as a technological nightmare and the heritage of Frankenstein, the other as a miraculous remedy for infertile couples. ${ }^{5}$ Central to this discussion, however, are issues like family, tradition, and marriage - which all the main actors define similarly. Meanwhile, other questions, such as access to reproductive technologies by gay or lesbian couples, are not discussed at all.

Silence and concealment are the discursive strategies. Actors use them along with other strategies, like normalization and naturalization of ART; denormalization, de-naturalization, and criminalization of IVF; vilification of IVF users; monsterization of IVF children; victimization of infertile women; and medicalization of language.

What is at stake in this discursive play? First of all: women's position in the Polish society, especially within the family. And second: the role of the Catholic Church in Poland, its discursive power and the influence on the government, parliament, law and the choices of ordinary people.

\section{Notes}

1 According to ESHRE, the European Society of Human Reproduction and Embryology, http://www.eshre.eu/ ESHRE/English/Guidelines-Legal/ART-fact-sheet/ page.aspx/1061. Accessed August 20, 2012.
2 Ibid.

3 However, as e.g. Barbara Dolińska convincingly argues in the Nauka magazine, many arguments deployed by the Polish opponents of IVF are based on unreliable research, the cited data can be broadly interpreted or quote research without providing any references. It especially applies to the controversial issue of the health of children born by means of IVF (2009: 96).

4 More recent feminist critiques are less condemnatory and radical, but they, too, pay attention to the deeply gendered nature of reproductive technologies; see Inhorn \& van Balen (2002: 15).

5 That, one should add, is not a Polish peculiarity; see Throsby (2004: 2).

\section{References}

Allison, J. 2011: Conceiving Silence: Infertility as Discursive Contradiction in Ireland. Medical Anthropology Quarterly 25:1, 1-21.

van Balen F. \& M.C. Inhorn 2002: Introduction. Interpreting Infertility: A View from the Social Sciences. In: M.C. Inhorn \& F. van Balen (eds.), Infertility around the Globe: New Thinking on Childlessness, Gender, and Reproductive Technologies. Berkeley, Los Angeles \& London: University of California Press.

Barczentewicz, M. 2008: Niepłodność - dziecko dobrobytu. Nasz Dziennik 19, January 23. www.naszdziennik. pl/bpl_index.php?typ=my\&dat $=20080123 \& i d=$ my21.txt. Accessed August 5, 2010.

Becker, G. 2000: The Elusive Embryo: How Women and Men Approach New Reproductive Technologies. Berkeley, Los Angeles \& London: University of California Press.

Bonaccorso, M.F. 2004: Programmes of Gamete Donation: Strategies in (Private) Clinics of Assisted Conception. In: M. Unnithan-Kumar (ed.), Reproductive Agency, Medicine and the State: Cultural Transformations in Childbearing. New York \& Oxford: Berghahn Books.

Bonaccorso, M.F. 2009: Conceiving Kinship: Assisted Conception, Procreation and Family in Southern Europe. New York \& Oxford: Berghahn Books.

Borowik, I. 2001: Pluralizm jako cecha przemian religijnych w kontekście transformacji w Polsce. In: T. Doktór \& I. Borowik (eds.), Pluralizm religijny $i$ moralny $w$ Polsce. Kraków: Nomos.

CBOS 2008: Opinions about Acceptability of In Vitro Fertilization. Research Report. January.

CBOS 2012: Postawy wobec stosowania zapłodnienia in vitro. Research Report. September.

Chełstowska, A. 2011: Stigmatisation and Commercialisation of Abortion Services in Poland: Turning Sin into Gold. Reproductive Health Matters 19, 37.

Collier, J.F., M.Z. Rosaldo \& S.J. Yanagisako 1992: Is there a Family? New Anthropological Views. In: B. Thorne \& M. Yalom (eds.), Rethinking the Family: Some Feminist Ques- 
tions. Boston: Northeastern University Press.

Corea, G. 1985: The Mother Machine: Reproductive Technologies from Artificial Insemination to Artificial Wombs. New York: Harper \& Row.

Cussins, Ch. 1998: Producing Reproduction: Techniques of Normalization and Naturalization in Infertility Clinics. In: S. Franklin \& H. Ragoné (eds.), Reproducing Reproduction: Kinship, Power and Technological Innovation. Philadelphia: University of Pennsylvania Press.

Czachorowski, M. 2008: Metoda zła moralnie, bo nie szanuje człowieczeństwa. Z Markiem Czachorowskim rozmawia Justyna Wiszniewska. Nasz Dziennik 19, January 23. http:// adonai.pl/nieplodnosc/?id=56. Accessed August 20, 2010.

Dolińska, B. 2009: Uczciwość i wiarygodność nauki odpowiedzialność za słowa w walce o dopuszczalność in vitro. Nauka 4, 87-101.

Dudziak, U. 2008: Bezdroża In vitro. Nasz Dziennik (dodatek Rodzina), January 23. http://www.szansaspotkania.net/index.php?page $=10055$. Accessed August 20, 2010.

Edwards, J., S. Franklin, E. Hirsch, F. Price \& M. Strathern 1993: Technologies of Procreation: Kinship in the Age of Assisted Conception. Manchester: Manchester University Press.

Franklin, S. 1995: Postmodern Procreation: A Cultural Account of Assisted Reproduction. In: F.D. Ginsburg \& R. Rapp (eds.), Conceiving the New World Order: The Global Politics of Reproduction. Berkeley: University of California Press.

Franklin, S. \& H. Ragoné (eds.) 1998: Reproducing Reproduction: Kinship, Power, and Technological Innovation. Philadelphia: University of Pennsylvania Press.

Franklin, S. \& S. Roberts 2006: Born and Made: An Ethnography of Preimplantation Genetic Diagnosis. Princeton: Princeton University Press.

Ginsburg, F.D. \& R. Rapp (eds.) 1995: Conceiving the New World Order: The Global Politics of Reproduction. Berkeley: University of California Press.

Gowin, J. 2009: Aborcja zarodka to zabicie dziecka: Z Jarosławem Gowinem rozmawia Paulina NowosielskaKucharska. February 3. http://ekai.pl/wydarzenia/wywiad/x17960/polska-aborcja-zarodka-to-zabicie-dziecka. Accessed August 20, 2010.

Graff, A. 2001: Swiat bez kobiet. Warszawa: WAB.

Graff, A. 2003: Lost Between The Waves? The Paradoxes of Feminist Chronology and Activism in Contemporary Poland. Journal of International Women's Studies 4:2, 1-30.

Hilgers, T. 2009: Alternatywa istnieje: Z Thomasem Hilgersem rozmawiają Joanna Bątkiewicz-Brożek i Maciej Müller. Kościół o metodzie in vitro: Bioetyka katolicka (bezplatny dodatek), December 13, 14-15.

Hoser, H. 2009: Cywilizacyjna debata: O najważniejszych problemach bioetycznych z ks. abp. Henrykiem Hoserem rozmawia Marcin Przeciszewski. Kościół o metodzie in vitro: Bioetyka katolicka (bezpłatny dodatek), December 13, 3-5.
Inhorn, M.C. \& F. van Balen (eds.) 2002: Infertility around the Globe: New Thinking on Childlessness, Gender, and Reproductive Technologies. Berkeley, Los Angeles \& London: University of California Press.

de Jong, W. 2009: Reproductive Technologies and the Concept of Normalisation. In: W. de Jong \& O. Tkach (eds.), Making Bodies, Persons and Families: Normalising Reproductive Technologies in Russia, Switzerland and Germany. Berlin, Hamburg \& Münster: LIT Verlag.

de Jong, W. \& O. Tkach (eds.) 2009a: Making Bodies, Persons and Families: Normalising Reproductive Technologies in Russia, Switzerland and Germany. Berlin, Hamburg \& Münster: LIT Verlag.

de Jong, W. \& O. Tkach 2009b: Researching Reproductive Technologies in East and West. In: W. de Jong \& O. Tkach (eds.), Making Bodies, Persons and Families: Normalising Reproductive Technologies in Russia, Switzerland and Germany. Berlin, Hamburg \& Münster: LIT Verlag.

Kirkman, M. 2008: Being a "Real" Mum: Motherhood through Donated Eggs and Embryos. Women's Studies International Forum 31, 241-248.

Klepacka-Środoń, M. 2008: 40 lat “Humanae vitae”. O ludzki kształt prokreacji: Z Marią Klepacką-Środoń rozmawia Małgorzata Jędrzejczyk. Nasz Dziennik 174, July 26-27. http://www.naszdziennik.pl/bpl_index.php?dat $=20080726$ \&typ=ro\&id=ro13.txt. Accessed August 20, 2010.

Komunikat z 352 posiedzenia plenarnego Konferencji Episkopatu Polski, 2010. June 20, 2010. www.duszpasterstworodzin.gniezno.opoka.org.pl/go.php/pl/varia/2010/ czerwiec/komunikat_z_352_zebrania.html. Accessed August 20, 2010.

Konik-Korn, M. 2008: Grzechy in vitro. Niedziela 2, 25.

Krawczak, A. 2010: List do redaktora naczelnego dziennika "Rzeczpospolita". www.nasz-bocian.pl/node/15804. Accessed August 20, 2010.

Laqueur, T.W. 2000: "From Generation to Generation": Imagining Connectedness in the Age of Reproductive Technologies. In: P.E. Brodwin (ed.), Biotechnology and Culture: Bodies, Anxieties, Ethics. Bloomington: Indiana University Press.

Le Breton, D. 2004: Genetic Fundamentalism or the Cult of the Gene. Body \& Society 10:4, 1-20.

List pasterski Episkopatu Polski na Niedzielę Świętej Rodziny 2008, December 28. http://ekai.pl/wydarzenia/temat_ dnia/x17191/biskupi-do-polskich-rodzin-nie-bojmy-sieadoptowac-dzieci/?print=1. Accessed August 20, 2010.

Martin, E. 1987: The Woman in the Body: A Cultural Analysis of Reproduction. Milton Keynes: Open University Press.

McNeil, M. 2007: Feminist Cultural Studies of Science and Technology. London: Routledge.

Michalik, J. 2009: Egzamin z dekalogu. Kościół o metodzie in vitro: Bioetyka katolicka (bezpłatny dodatek), December 13,2 .

Muszyńska, M. 2009: Zapłodnienie in vitro - szansa na godne 
rodzicielstwo. Wystuchanie Obywatelskie, February 23. www.federa.org.pl/Informacje/Wysluchaniezapis02.2009. pdf. Accessed August 20, 2010.

Neresini F. \& F. Bimbi 2000: The Lack and the "Need" of Regulation for Assisted Fertilization: The Italian Case. In: A.R. Saetnan, N. Oudshoorn \& M. Kirejczyk (eds.), Bodies of Technology: Women's Involvement with Reproductive Medicine. Ohio: Ohio State University Press.

Oświadczenie Zespołu Ekspertów KEP ds. Bioetycznych ws. in vitro 2010. March 24. http://www.piotrskarga.pl/ ps, 5005,2,0,1,I,informacje.html. Accessed August 20, 2010.

Peperkamp, E. 2008: The Fertile Body and Cross-Fertilization of Disciplinary Regimes. Technologies of Self in a Polish Catholic Youth Movement. In: N. Dyck (ed.), Exploring Regimes of Discipline. New York \& Oxford: Berghahn Books.

Pieronek, T. 2009: Pierwowzorem in vitro jest Frankenstein. Z biskupemTadeuszemPieronkiemrozmawiaWojciechHarpula. http://wiadomosci.onet.pl/1527301,240,1,1,pierwowzorem_ in_vitro_jest_frankenstein,kioskart.html. January 16. Accessed August 20, 2010.

Rabinow, P. 1996: Essays in the Anthropology of Reason. Princeton: Princeton University Press.

Radkowska-Walkowicz, M. 2012a: Aaaby wynająć brzuch: Antropologiczne konteksty macierzyństwa zastępczego. In: R.E. Hryciuk \& E. Karolczuk (eds.), Pozegnanie z Matka-Polka? Warsaw: Warsaw University Press.

Radkowska-Walkowicz, M. 2012b: The Creation of "Monsters": The Discourse of Opposition to In Vitro Fertilization in Poland. Reproductive Health Matters 20, 40.

Ragoné, H. 2004: Surrogate Motherhood and American Kinship. In: R. Parkin \& L. Stone (eds.), Kinship and Family: An Anthropological Reader. Oxford: Blackwell Publishing Ltd.

Rapp, R. 2001: Gender, Body, Biomedicine: How some Feminist Concerns Dragged Reproduction to the Center of Social Theory. Medical Anthropology Quarterly 15:4, 466-477.

Rusiecka, B. 2010: http://adonai.pl/nieplodnosc/?id=90. Accessed August 20, 2010.

Saetnan, A., N. Oudshoorn \& M. Kirejczyk (eds.) 2000: Bodies of Technology: Women's Involvement in Reproductive Medicine. Ohio: Ohio University Press.

Sawicki, J. 1991: Disciplining Foucault: Feminism, Power, and the Body. New York \& London: Routledge.

Sawicki, J. 1999: Discipling Mothers: Feminism and the New Reproductive Technologies. In: J. Price \& M. Shildrick (eds.), Feminist Theory and the Body: A Reader. New York: Routledge.

Skibniewska, A. 2009: Szczęcie z in vitro. Przeglad 24. http:// przeglad-tygodnik.pl/index.php? site $=$ artykul\&id $=15296$. Accessed August 20, 2010.
Spar, D.L. 2006: The Baby Business: How Money, Science, and Politics Drive the Commerce of Conception. Boston, Massachusetts: Harvard Business School Press.

Squier, S.M. 1999: Negotiating Boundaries: From Assisted Reproduction to Assisted Replication. In: E.A. Kaplan \& S.M. Squier (eds.), Playing Dolly: Technocultural Formations, Fantasies, and Fictions of Assisted Reproduction. New Brunswick, New Jersey \& London: Rutgers University Press.

Stanworth, M. 1987: Reproductive Technologies: Gender, Motherhood and Medicine. Minneapolis: University of Minnesota Press.

Strathern, M. 1992: Reproducing the Future: Essays on Anthropology, Kinship and the New Reproductive Technologies. Manchester: Manchester University Press.

Szczerba, B. 2009: Zapłodnienie in vitro - szansa na godne rodzicielstwo. Wystuchanie Obywatelskie, February 23. www.federa.org.pl/Informacje/Wysluchaniezapis02.2009. pdf. Accessed August 20, 2010.

Thompson, Ch. 2002: Fertile Ground: Feminist Theorize Infertility. In: M.C. Inhorn \& F. van Balen (eds.), Infertility around the Globe: New Thinking on Childlessness, Gender, and Reproductive Technologies. Berkeley, Los Angeles \& London: University of California Press.

Thompson, Ch. 2005: Making Parents: The Ontological Choreography of Reproductive Technologies. Cambridge: The MIT Press.

Throsby, K. 2004: When IVF Fails: Feminism, Infertility and Negotiation of Normality. London: Palgrave.

Turney, J. 1998: Frankenstein's Footsteps. New Haven \& London: Yale University Press.

Unnithan-Kumar, M. 2004: Introduction: Reproductive Agency, Medicine and the State. In: Reproductive Agency, Medicine and the State: Cultural Transformations in Childbearing. New York \& Oxford: Berghahn Books.

Unnithan-Kumar, M. (ed.) 2004: Reproductive Agency, Medicine and the State: Cultural Transformations in Childbearing. New York \& Oxford: Berghahn Books.

Magdalena Radkowska-Walkowicz is Assistant Professor at the Institute of Ethnology and Cultural Anthropology, University of Warsaw, Poland. Her research interests are anthropology of the body, new reproductive technologies, gender, and anthropology of literature. In 2008 her book Od Golema do Terminatora: Wizerunki sztucznego człowieka $w$ kulturze (From Golem to Terminator: Images of the Artificial Man in the Culture) was published (Warsaw: Wydawnictwa Uniwersytetu Warszawskiego).

(m.radkowska-walkowicz@uw.edu.pl) 


\section{COMMENTS}

K. Körber \& I. Merkel (eds.): Ethnologia Europaea 42:2

eJournal (c) Museum Tusculanum Press 2013 :: ISBN 9788763541145

www.mtp.hum.ku.dk/details.asp?eln=300323 


\title{
KAROL'S KINGDOM
}

\author{
Marie Sandberg
}

“(...) We are like the Great Britain guys. We have our cup of tea together," Karol explains, after his wife and one of his two sons back home in Poland have ended their daily talk on Skype. We are sitting in Karol's room, which he shares with his colleague from the construction site placed nearby, just outside a middle-size town about one hour drive from Copenhagen, Denmark. The room forms part of a dormitory and is approximately 12 square metres, has two single beds, a toilet with shower, a fridge and access to a pretty worn-out, shared kitchen. Together with his colleague he pays 450 euro rent, and importantly this includes free Internet access. Still placed at the computer, after the Skype call has finished, I am trying not to look at the 44-inch flat-screen TV that decorates the wall. The Polish Tvn channel is broadcasting a show on breast enlargements, so the living pictures are rather eye-catching. Karol has invited us and obligingly he tells us about how he ended up here in Denmark as a foreman for a small team of Polish workers on a building project run by a Danish entrepreneur. Here he earns approximately twice as much as he could in Poland. Karol works 46 hours Monday till Saturday for three weeks and then he returns to his family in Poland during the fourth week. "Everything we need for our living is here. For existing. (...) It's my kingdom,” Karol states.

While sitting there in Karol's room, I cannot help pondering why Karol chooses this way of life. What does it take to break up from the well-known routines at home in order to live in a small, shared room in a dormitory without having the family around? What I learned from Karol is that it takes more than one wo/man's choice to make a migratory practice a reality. Rather, a whole range of heterogeneous entities, settings and devices are involved. As they are assembled in various ways they take an active part in rendering a migratory practice such as Karol's both possible and desirable. Close allies are, for example, the specific means of transportation used when moving back and forth across the border; the social networks and networks of communication; the institutional as well as private actors facilitating labour migration across borders, such as recruiters and housing or estate agents; the specific regulations and tax allowances making working abroad even more financially attractive; the special agreements between employers, migrant workers, and the Danish trade union, which enables the pooling of working hours, not to mention the role of the family members, and their acceptance and active partaking in the migratory venture.

In order to grasp the character and various rationales of migratory movements it is necessary to put a human face on migration processes as suggested by Favell $(2008,2009)$. However, in doing so, it is also decisive to go beyond a frame of explanation that focuses solely on various acts of choice (cf. van der Velde \& van Naerssen 2011). Overall, this special issue of Ethnologia Europaea on "Imagined Families in Mobile Worlds" is taking important steps towards a broader conceptualization of practice than one of rational choice-making. Further, in scrutinizing the emergence of new models of familiarity beyond the domestic unit in transnational space the articles avoid focusing on mobile individuals alone. 


\section{Outline}

In this commentary I discuss how ethnology can contribute to the interdisciplinary field of international migration studies. Such a contribution, I suggest, can take the form of historically informed, materiality-oriented ethnographies which provide a basis for further examining the interrelatedness between migratory regimes and everyday life practices. Using examples from a current research project on Polish working migrants in Copenhagen, ${ }^{1}$ I will offer a few reflections on the conceptual understanding of migratory practices. I propose a broad comprehension of such practices that can be seen as complex matters of feasibility as opposed to a rather reductionist question of choice. I am inspired by Maja Povrzanović Frykman's call for a "shift of ethnographic focus towards people's practices in connection with migration" (2008: 17, original emphasis) arguing that "only ethnographic methods can capture what migrants actually do - in the places of their everyday life, in the places they keep returning to and on the journeys between them" (ibid.). Further, I point out how the authors of this special issue raise important questions and provide new knowledge by paying analytical attention to practices of migration; their historicity and materiality/technology. I therefore, firstly, direct my attention towards migration studies and the need for including practice approaches in the rethinking of the so-called "mobility turn". Secondly, I look at the interrelatedness between migration and historicity, and thirdly, I pick up on the role of materiality and technology as co-constructors of migration practices. In conclusion I discuss how the scrutinization of interfaces between migratory regimes and migration practices can both add new insights to the interdisciplinary field of migration studies and develop new questions for future ethnological inquiry.

\section{Migration Studies and the Mobility Turn}

The growing fields of interdisciplinary migration studies, mobility studies and globalization studies often depict a world that has become more mobile than ever before. However, in a Eurobarometer survey conducted by the Dublin-based European
Foundation for the Improvement of Working and Living Conditions (of the EU) in 2005, data indicate that "EU-citizens who had ever lived in another EU member state amounted to $4 \%$ of the population" (Favell, Recchi \& Kuhn et al. 2011: 21). Worldwide the numbers are surprisingly similar: only $3 \%$ of the world's population is living outside the country where they were born (United Nations 2009). These data together with results from similar surveys compel van der Velde and van Naerssen to state that, rather than mobility, "immobility is still the rule" (2011: 219). Such a statement is thought-provoking in an era that is frequently characterized as "an era of mobility" and in a space often referred to as a "borderless Europe" (cf. Andersen \& Sandberg 2012). The question is, has the highly praised free mobility across the EU internal borders remained much more a "political dreamscape" (Löfgren 2008) than a reality of everyday life in Europe?

\section{Migration and Practice}

However, as recent discussions within migration and mobility studies have shown, the question of increased mobility needs to be rethought (Canzler, Kaufmann \& Kesselring 2008; Favell 2009; Larsen, Urry \& Axhausen 2006; Sheller \& Urry 2006; Urry 2008). To state that either you are a migrant on the move or a stationary resident simply makes no sense. For example, not all East-West migrants of Europe seem to stay on a permanent basis in their country of destination. As shown by Pijpers (2007), it is very seldom that East-West labour migration is uni-directional, which means that it is inaccurate to characterize the $2004 \mathrm{EU}$ accession countries exclusively as emigration countries. In several Eastern European countries the numbers of return migrants and transit migrants are growing. Within recent years a classical emigration country like Poland receives labour migrants from Ukraine, Belarus and other countries of the former Soviet Union which makes notions such as "chain migration" relevant to apply (ibid.). This development of new concepts for migration processes confirms the need to critically evaluate the analytical potential of thinking in commonsensical dichotomies such as mobility 
vs. immobility, "the movers" vs. "the stayers", the "sedentary" vs. the "nomads", a point that was also made by the transnational approach migration studies already in the early 1990s (Glick Schiller, Basch \& Blanc-Szanton 1992; Düvell 2009). Various flows of migration take place in an "extensive system of mobilities" across and beyond EU borders which make dichotomies together with divisions of home/host or sending/receiving countries rather useless (Favell, Recchi \& Kuhn et al. 2011: 22). We should therefore not forget the many different ways migration is enacted and made possible in practice (cf. Povrzanović Frykman 2008). When migration practices are put under empirical scrutiny, it is very unlikely that we will discover practices of either mobility or settlement. On the contrary, we might find complex patterns of mobility/immobility even within the same migratory practice.

Therefore I find this special issue on imagined families stimulating. In her article "Grounding the Family: Locality and its Discontents in Popular Genealogy" Elisabeth Timm convincingly argues for a relational complementarity between mobility and immobility. When analysing the role of locality in the use of parish registers in Austrian popular genealogy it becomes clear that "'settledness' is not a given, and that 'migration' is not its Other". Rather, "mobility and immobility can only be adequately understood as relational complements" (Timm, this issue, p. 39). Through three Austrian cases Timm illustrates the active role played by genealogies in the ideological forming of families. Further, Timm shows how a production of "settledness" has been tightly knitted together historically with the idea of family kinship as linked to territory (together with house, estate and property). This examination over time of the constant production and reproduction of associating kinship and "settledness" within a territory is thought-provoking and adds new insights to the mobility turn within migration studies (cf. Rolshoven 2007).

\section{Migration and Historicity}

Apart from the rethinking of the division between mobility and immobility a second point of discus- sion within migration studies is the need for greater awareness of historical migration processes (cf. Favell 2008, 2009; Düvell 2009). It is often forgotten that waves of intra-European as well as extraEuropean working migrations took place also before the First World War (cf. Kolstrup 2010). Until the First World War Europe experienced a period of free movement of labour where passports and other kinds of entry documents were not even required (Wimmer \& Glick Schiller 2002). To display such historical continuities in recent labour migration movements of Europe is hence crucial.

I would like to emphasize the article by Karen Körber entitled "So Far and yet so Near: Present-Day Transnational Families". Her historical comparison between labour migration within transnational families in Austria and Germany during the 1960s and 1990s respectively provides a fine illustration of how migratory movements have been facilitated and regulated differently by national authorities as well as EU legislation over time. In contrast to the present-day East-West migration of Europe, the labour migration of the 1960s was based on labour recruitment agreements between Western European countries (such as Germany) and South and Eastern European countries such as Italy, Greece, Turkey and the former Yugoslavia. These "guest worker" agreements secured among other things work permits and the legal status of the migrants' residential status in the country of destination. Due to special restrictive requirements introduced in most of the "old" EU member states the present-day East-West labour migration differs from the "guest worker" agreements of the 1960s. After the EU accessions of 2004 the "old" EU member states (with the exceptions of Sweden, Ireland and the U.K.) introduced special - and temporary - agreements regulating, among other things, the numbers of labour migrants and the issuing of work permits for the "new" EU member states (cf. Pijpers 2006, 2007). Consequently, as according to Körber, this type of regulation "limits in principle the right of people from Eastern Europe to move and reside freely and abolished the right to settle - with few exceptions - almost entirely" (Körber, this issue, p. 19). Comparing such dif- 
ferences in legal conditions and special agreements among EU member states can shed new light on our understanding of current migratory movements as well as of those in the past.

\section{The Materiality and Technology of Migration Practices}

A third point of discussion, where I think ethnological approaches can contribute to international migration studies, is related to the attention towards materiality and technology of migration practices. In order to know cross-border practices better, we need to explore how these practices are attached to and receive backup from specific but heterogeneous assemblages of other actors and entities. We must therefore consider not only the practices and their variable differences but also take the settings, materials and devices that enable migratory movements into account. I would like to draw on the piece by Körber again, because she clearly shows how communication technologies are active allies in the production of family at and across a distance.

Positioning herself within the transnational research approach to family studies, Körber focuses not only on mobile actors, but also on family members that are "staying behind", "at home". The focus is chosen in order to analyse the nurturing of the social and symbolic family member relations that are indeed challenged by the migration process. With this analytical strategy Körber emphasizes the practices, strategies and negotiations through which family life is created across time and space instead of conceptualizing the family as a community consisting of individual units.

That there are intimate and intricate links between the use of new communication technologies and the specific production of familiarity is clearly illustrated in the case of Ingrida Einars presented by Körber. Einars is a woman from Kaunas, Lithuania, who labour migrated to Germany in 2004 leaving her teenage daughter at home with the grandparents. Körber shows how the initially troubled and conflictridden communication between the teenage daughter and her mother becomes improved through the use of emails instead of Skype/webcam. Without the camera the typewritten contact provides a relieving space for communication that works well for the teenage daughter who dyes her hair and pierces her skin also without her mother's approval. Likewise the communication becomes more relaxed for the mother who can momentarily focus on what the daughter writes, rather than her appearance. Hence, a virtual closeness is maintained between mother and daughter across borders. Körber concretizes the paradox pointed at by the editors in the Introduction to this special issue, namely that

despite geographical distance and the experience of dispersal, the very social group whose core elements include spatial proximity and direct community is capable of sustaining the family virtually as its principal point of orientation and reference. As such, it is proving both resistant and creative in the face of the new demands of globalized societies. (Körber \& Merkel, this issue, p. 5)

\section{From Matter of Choice to Matters of Feasibility}

So far I have argued that the strength of ethnological approaches to international migration studies in particular lies in the depicting of patterns of mobility/immobility when analysed in practice, as well as in the incorporation of historicity and materiality/ technology of migration processes. I would now like to return to the before mentioned focus on the migrant and the migratory process as a simple matter of choice. Following the argument of van der Velde and van Naerssen (2011) we need to broaden the explanatory figure usually called "the decision-making process" of migratory movements. Overall this special issue contributes to such broadening because it focuses on the family as an important co-actor in migration processes (cf. Kolstrup 2010). However, the article by Sabine Hess entitled "How Gendered is the European Migration Regime? A Feminist Analysis of the Anti-Trafficking Apparatus" calls in particular for a further discussion on the concept of choice. This contribution deals with the effects and implications of border regulations and migration policies within the area of trafficking. 
Situating herself as a researcher in medias res among counter-trafficking NGO's, policy makers, women's rights movements, and feminist research agendas, Hess compellingly shows how anti-trafficking policies in fact contribute to a victimization or de-subjectification of migrant women. For example when official European immigration policies only grant residence permits as a result of marriage, heteronormative ideals of gender interdependencies and differences are reproduced, according to Hess. Appallingly such regulations resemble the mechanisms of the trafficking migration industry when trafficked women get caught in exploitative nets of (male) dealers and middle-men which yet again contribute to the reproduction of a gendered dependency pattern.

However, as a further point Hess shows that migrating women cannot be depicted as victims only. Her ethnographic analyses of everyday life migration patterns indicate that the destiny of these women in question cannot be judged solely as either initiated by force or as volunteered by choice. For these women, it is not a question of either/or, but rather a matter of both/and. Voluntary migration and migration by force cannot be divided into two neat categories. Rather, "voluntary actions and direct and structural violence intersect in contradictory manners and are judged and negotiated in myriad ways, both in migrants' interpretations and in their actions" (Hess, this issue, p. 56). This article therefore both constitutes a counter narrative to singularizing discourses of migrating women-as-victims as well as exemplifies how migratory movements cannot be reduced to a rational choice. It confirms the capability of ethnographic analyses of everyday life migration patterns to depict the various and often ambivalent strategies and negotiations among in this case migrant women.

\section{Linking Migratory Regimes and Migratory Practices} Introducing the articles within this special issue, the guest editors emphasize that "by interlocking ethnographic and discourse-analytical methods and combining them with gender theory, they share a focus on the technologies, genealogies, policies, and regu- lations that participate crucially in the construction of family, gender, and bodies" (Körber \& Merkel, this issue, p. 6). No doubt these contributions give important insights into concrete experiencing and shaping of migration processes in practice. As a final point of discussion I would like to address two questions: How are such practices constituted? How are practices related to, involved in and presupposed by other practices? Indeed, as I have already argued here, practices do not unfold in a vacuum; they are made feasible by other practices, settings, materials, and devices. Within this special issue a common point of departure for a number of the authors seems to be the concept of regimes, such as the "European border regime", "European immigration regime", "security regimes" or regimes of free mobility across borders. Yet further questions arise, such as what constitutes one regime as compared to others? Where do the analyses of various regimes and their impact leave the migrants crossing the borders? Are migrants passive products of the regimes or how can regimes be resisted? Leaving the concept of "regime" to some extent untouched makes it easy to fall into an explanatory trap: either the analyses provide evidence of how migrants are subjected to various regimes or they seek to stress the agency of mobility across borders (cf. Favell, Recchi \& Kuhn et al. 2011). The contributions show the potential of the concept of "regime", but I see an important future challenge in discussing more thoroughly what the notion of regimes entails and what it does to our understanding of the connections between practices of different kinds.

\section{The Kingdom}

As is evident from this collection of Ethnologia Europaea contributions, there are several practices and entities involved in past and current migratory movements across intra-European borders.

It is certainly not a one-man show to migrate. Family members who are staying at home take active part in decision-making processes and render the practices of mobility/immobility possible. The case of Karol has illustrated the importance of the support from his wife and sons who contribute to 
rendering "Karol's kingdom" feasible and desirable. The daily "five-o-clock tea" on Skype forms a particular assemblage of entities, devices and settings that seems to be in accordance with Karol's idea of what a good family relation is. It is only in collaboration with a (nother) specific but heterogeneous assemblage of allies that Karol manages to remain attractive to the Danish job market by fitting in perfectly with the ideal migrant "flexi-worker" that is hard working, flexible, and mobile (Pijpers 2007). Finally, the historical fact that there have been working migrants before him, such as Polish rural workers of the nineteenth and early twentieth century, also might influence his possibility to succeed. To explore patterns of mobility/immobility practiced over time thus constitutes an important task for further ethnological scrutiny (cf. Kolstrup 2010; Nellemann 1981). By paying attention to the historicity, materiality, and technology it becomes possible to depict the different ways Karol's migratory practice of mobility/immobility correspond to his idea of the "good life".

As I have argued here, there is a general need for greater empirical and historical awareness within the interdisciplinary field of migration studies in order to break out from reductionist explanation models of rational choice and to avoid that questions of mobility and immobility are turned into misleading terms of either-or. The need for empirically rich depictions of everyday life mobility and migration patters calls for further ethnographic studies similar to those of the special issue at hand.

\section{Note}

1 The example derives from an ongoing research project on Polish working migrants in the area of Copenhagen, Denmark, conducted by Associate Professor Niels Jul Nielsen and Assistant Professor Marie Sandberg, at the Ethnology Section, the Saxo Institute, University of Copenhagen (2011-).

\section{References}

Andersen, Dorte J. \& Marie Sandberg 2012: Introduction. In: Dorte J. Andersen, Martin Klatt \& Marie Sandberg (eds.), The Border Multiple: The Practicing of Borders between Public Policy and Everyday Life in Europe. Aldershot: Ashgate Border Regions Series.
Canzler, Weert, Vincent Kaufmann \& S. Kesselring 2008: Tracing Mobilities - An Introduction. In: Weert Canzler, Vincent Kaufmann \& Sven Kesselring (eds.), Tracing Mobilities: Contributions from the Cosmobilities Network. Abingdon, Oxdon, GBR: Ashgate Publishing Group, pp. $11-17$.

Düvell, Franck 2009: Migration, Minorities and Marginality: New Directions in Europe Migration Research. In: Chris Rumford (ed.), The SAGE Handbook of European Studies. London: SAGE Publications Ltd., pp. 329-346.

Favell, Adrian 2008: The New Face of East-West Migration in Europe. Journal of Ethnic Migration Studies 34:5, 701-716.

Favell, Adrian 2009: Immigration, Migration, and Free Movement in the Making of Europe. In: Jeffrey T. Checkel \& Peter J. Katzenstein (eds.), European Identity. Cambridge: Cambridge University Press, pp. 167-189.

Favell, Adrian, Ettore Recchi \& Theresa Kuhn et al. 2011: The Europeanisation of Everyday Life: Cross-Border Practices and Transnational Identifications among EU and Third-Country Citizens. State of the Art Report. Eucross Working Papers no. 1. http://www.eucross. $\mathrm{eu} / \mathrm{cms} /$ index.php? option $=$ com_docman \&task $=$ cat_ view\&gid=7\&Itemid=157. Accessed August 31, 2012.

Glick Schiller, Nina, Linda Basch \& Cristina Blanc-Szanton 992: Transnationalism: A New Analytical Framework for Understanding Migration. In: Nina Glick Schiller, Linda Basch \& Cristina Blanc-Szanton (eds.), Towards a Transnational Perspective on Migration, Race, Class, Ethnicity, and Nationalism Reconsidered. New York, N.Y.: New York Academy of Sciences Annals of the New York Academy of Sciences.

Kolstrup, Søren 2010: Polske stemmer: Polske indvandringsbølger 1892-2008. Copenhagen: Frydenlund.

Larsen, Jonas, John Axhausen \& John Urry 2006: Mobilities. In: Jonas Larsen, John Axhausen \& John Urry (eds.): Mobilities, Networks, Geographies. Aldershot: Ashgate Publishing Group, pp. 47-62.

Löfgren, Orvar 2008: Regionauts: The Transformation of Cross-Border Regions in Scandinavia. European Urban and Regional Studies 15:3, 195-209.

Nellemann, George 1981: Polske landarbejdere i Danmark og deres efterkommere: Et studie af landarbejderindvandringen 1893-1929 og indvandringens integration i det danske samfund $i$ to generationer. Copenhagen: Nationalmuseets Forlag.

Pijpers, Roos 2006: 'Help! The Poles are Coming': Narrating a Contemporary Moral Panic. Geografiska Annaler, 88B:1, 91-103.

Pijpers, Roos 2007: Between Fear of Masses and Freedom of Movement: Migrant Flexiwork in the Enlarged European Union. Doctoral thesis, Nijmegen School of Management, Radboud University Nijmegen, The Netherlands.

Povrzanović Frykman, Maja 2008: Beyond Culture and 
Identity: Places, Practices, Experiences. Ethnologia Europaea 38:1, 13-22.

Rolshoven, Johanna 2007: The Temptations of the Provisional. Multilocality as a Way of Life. Ethnologia Europaea $37: 1-2,17-25$.

Sheller, Mimi \& John Urry 2006: The New Mobilities Paradigm. Environment and Planning A, 206-226.

United Nations Department of Economic and Social Affairs 2009: Population Division 1. International Migration Report 2009.

Urry, John 2008: Moving on the Mobility Turn. In: Weert Canzler, Vincent Kaufmann \& Sven Kesselring (eds.), Tracing Mobilities: Towards a Cosmopolitan Perspective in Mobility Research. Aldershot: Ashgate.

van der Velde, Martin \& Ton van Naerssen 2011: People, Borders, Trajectories: An Approach to Cross-Border Mobility and Immobility in and to the European Union. Area 43:2, 218-224.
Wimmer, Andreas \& Nina Glick Schiller 2002: Methodological Nationalism and beyond: Nation-State Building, Migration and the Social Sciences. Global Networks 2:4, 301-334.

Marie Sandberg, Ph.D., is Assistant Professor of Ethnology at the University of Copenhagen. Her research focuses on the rethinking of European integration processes, border practices and experiences in everyday life, labour migration within the EU and the reordering of borders in Europe - past and present. Among her recent publications is the book The Border Multiple: The Practicing of Borders between Public Policy and Everyday Life in Re-Scaling Europe (edited together with Dorte J. Andersen \& Martin Klatt, 2012, Ashgate Border Regions Series).

(sandberg@hum.ku.dk) 


\title{
FROM ACCOMPANYING FAMILY MEMBER TO ACTIVE SUBJECT Critical Perspectives on Transnational Migration
}

\author{
Beatriz Lindqvist
}

Today, a growing number of people spend their lives beyond the borders of nation states. They create homes, families and identities that are not easily understood if one adheres to the concept of "true belonging" as meaning solidly anchored to one territory, one culture and one language. Even in the era of globalization, however, this concept retains its force. It is, after all, still the nation state, and only the nation state, that guarantees individuals' fundamental rights and grants them their true home, their proper place. Refugees are still viewed as exceptional, for they lack the basic protection which only the native country can give (see Bauman 1998). Thus, despite modern global mobility, the nation state's legal regulations, border controls and migration policies are still of pre-eminent importance. During periods of rapid social change, the nation, accordingly, often becomes a socially, culturally and politically charged subject within a symbolic battle over how to define so-called normal relations and healthy family ties. The breakthrough of industrialism and urbanization and the modernization of the European welfare states meant new ways of conceptualizing and organizing marriage, parenthood and family life (see Frykman \& Löfgren 1987). Today, the family is again the focus of social debates conducted in the light of growing international migration, the transformation of the welfare state, assisted fertilization of childless couples and the emergence of same-sex parents in "rainbow" families.
International research on ethnic relations and international migration has shown how many migrants' everyday life takes place in several places simultaneously. Personal relations and family economy, life goals and identities are formed by social interrelations that reach across national borders sometimes beyond continents. Transnational contacts and family ties link together geographically disperse worlds. In many cases, they create a virtual homeland consisting of several different places. Marita Eastmond and Lisa Åkesson (2007) have shown that global families are shaped by interplay between migrants' lives, as lived in different local contexts, and the global communities of which they form a part. Munzoul Assal's 2003 study of Somali and Sudanese living in Norway discusses how these engage in an intense social exchange with relatives and friends outside Norway's borders. This exchange is, moreover, not confined to people in the migrants' country of origin; it reaches out to several other parts of the world, as well. Assal argues that one must position these groups' views on home, family and belonging against this wide, mobile horizon. He also calls attention to the number and variety of everyday actions and communication forms that together create a home that lies beyond the narrow logic of the nation state. Family and kin, here, is not something one simply is or has. One creates family in the everyday practices of sending money to relatives, celebrating holidays together, participating in ethnic 
associations, joining Facebook groups and chatting with relatives who can partake of family pictures. The same findings emerge in Anna Lindley's study of Somali refugees in Great Britain (2010). She shows that refugees' money-transfers to relatives in other countries involve more than sending resources from afar. They are also a means of providing moral support, of exchanging information of how it is to live and work in different countries and on the opportunities and difficulties encountered in one's everyday life.

Family and kinship are formed in many different ways, going far beyond the community (if any) constituted by members of a biological group. Social, cultural and emotional ties are essential to communities that extend over time and space. In this edition of Ethnologia Europaea, ethnographers use case studies of migrants' own experience and perspectives to illuminate these processes. The authors show how close family relations are created despite geographical distance, in studies of how people handle the complex and sometimes contradictory demands that a transnational life entails. This special issue's broad spectrum of empirical studies ties together two highly topical theoretical debates. The first is concerned with transnational migration, the second with family and gender. The case studies are diverse and imaginative, ranging from assisted fertilization through sex work to nuns' and migrants' accounts of their lives. Körbel and Merkel's thoughtful and well-structured introductory text shows how the different texts are linked in a dialogue "crosswise" over a number of empirical fields, in the cross-roads, of the major research themes of transnational migration, family and gender.

The growing corpus of international literature on transnational networks paints, in broad brushstrokes, a dark picture of a strongly polarized world in which a privileged cosmopolitan elite and faceless global market forces rapidly cross all and any borders, while an ever-growing mass of refugees and paperless migrants risk their lives to circumvent national border controls, only to end up at the mercy of human smugglers in the West. This somber picture has replaced earlier visions of globalization's international brotherhood with dystopian images of global exploitation, trafficking and increasing marginalization. Such dichotomizing images are, of course, problematic. They tend to be mutually self-enforcing, depending, as they do, on the same type of binary logic. The articles in this volume are, therefore, a welcome contribution to the discussion. They approach transnational processes from below, from the point-of-view of individual experiences. This gives new visibility to the complexity and ambivalences in different forms of transnational imagined families.

Earlier migration research often took as its point of departure the processes that brought migrants to a new country. Equally often, the unquestioned norm was to focus on a male subject - the adult male migrant, sometimes accompanied by wife and children, encountering opportunities and difficulties in the new country. The inquiry was, finally, framed in terms of how people who were torn loose from their "natural" context adapted to the receiving country. The studies in this issue provide a different, and innovative, type of analysis.

A common point of departure in the articles is Nina Glick Schiller's discussion of the concept of a "transnational social field". Glick Schiller shows how immigrants can construct ties to two or more nation states. This allows appreciation of how immigrants concurrently partake in the daily life of their country of origin, with all the political, social and emotional implications that entails, and in the everyday life of their new country, participating in the daily communities created at home, among friends and acquaintances, and at the workplace. An important point emphasized by the articles in this issue is that this type of simultaneous multi-national daily life applies not only to migrants who have changed countries, but also to those of their relatives and friends who have stayed in the country of origin - that is, have not physically crossed nation-state borders. In 2008, Lewitt and Glick Schiller distinguished between "transnational ways of belonging" and "transnational ways of being" (2008: 189). Belonging, they argue, is based on ideas of kinship ties, roots, origin and ethnicity. No matter where in the 
world a person lives, it is assumed that she or he is a member of a group united by a common past and a "community of fate". This belonging is unaffected by the person's movement across national borders. Ways of being, on the other hand, signify the ways in which a person can exist and interact over borders, without necessarily saying anything about where that person feels at home or about his or her self-identification. Notions of belonging address the ways in which people use remembrance, nostalgia, narratives and artifacts to reach out to other places, often in other countries - whether they live as migrants or are among those staying behind in their native locality.

Helma Lutz has provided a detailed discussion of the theoretical and methodological implications of an intersectional approach to migration (Lutz, Herrera Vivar \& Supik 2011). In the same vein, ethnologist Maja Povrzanović Frykman (2011), in her current research project The Transnational Life of Objects: Material Practices of Migrants (financed by the Swedish Research Council), discusses a closely related way of viewing transnationalism. She sees it as a ribbon or flow of people, ideas and things over national state borders. Lewitt and Glick Schiller develop the point of analytical distinctions between the concepts of being and belonging as follows:

If individuals engage in social relations and practices that cross borders as a regular feature of everyday life, then they exhibit a transnational way of being. When people explicitly recognize this and highlight the transnational elements of who they are, then they are also expressing a transnational way of belonging. Clearly, these two experiences do not always go hand in hand. (2008: 189-190)

\section{A Transnational Service Sector}

Every year thousands of women leave their countries of origin to work in richer countries, finding employment within the domestic sector as servants, child minders or personal assistants for elderly and sick in well-to-do families (Lindio-McGovern \&
Wallimann 2009; Parreñas 2001; Yeates 2009). A large proportion of these women migrate legally, their visa, tickets, contracts and work permits provided by employment agencies. A still larger proportion, hoping to penetrate EU borders, put their trust in illegal contractors (Agustin 2007). In many cases, the home countries' governments encourage this emigration: The money that the women send home is of great importance to the country's monetary reserves. Most of the women involved are between 18 and 40 years of age; they have varying educational backgrounds. Many leave children behind in the care of grandparents or other relatives. The primary reason for these women's migration is low family income - too low to cover the family's most basic needs. Often, the woman's subsequent earnings, sent home from abroad, serves to improve the family's long-term economy, through (for instance) making it possible to start a small business in the home town. These prospects encourage many women to leave their homes and countries of origin, traveling, sometimes, to nations in other continents (Ehrenreich \& Handschild 2003).

My own research on women from the Baltic States working in the Scandinavian sex industry shows that their employment within economic sectors regarded as socially low-value and morally dubious can be given a different meaning when viewed in terms of earnings earmarked for a particular use. Women so employed can retain their feeling of self-worth by placing their personal sacrifices within a discourse of respectability - the respectability of taking responsibility for one's family. Fulfilling their duty as the family's breadwinner is defined as the highest virtue. Accordingly, migrant sex-workers may position themselves as responsible and respectable rather than as victims - the position given them in main-stream Swedish discourses - or as the "dirty whores" of their home-countries' discourse.

The fact that private services involving bodily contact and touch are sold by migrants from the southern parts of the globe and Eastern Europe to West Europeans and Americans maintains an ethnic segmentation of work. This confirms and 
strengthens the social division between a national "us" and a foreign "them", as well as a division between different sorts of women (Lindqvist 2007, 2008). It cements an essentialist understanding of well-paid productive work as the purview of wellqualified, independent, self-conscious and reflexive women from the Western world. Reproductive work joins other forms of lowly-esteemed work as the natural occupation of under-qualified, lowearning and unreflexive foreign women (Mohanty 2003). According to several studies, the increasingly global market economy has, when conjoined with the feminization of poverty, transformed reproductive work into a transnational economic sector that operates, in large part, unseen (see Ehrenreich \& Handschild 2003; Parreñas 2001).

This gives us the context for understanding the young women who arrive in European countries to work, in periods, either on their way to other countries or as a temporary solution to the problem of earning a living. Intimacy, bodily contact and care are important pillars in this mobile employment market, a market which transforms those involved into senders and receivers. The services that are sold are almost all connected to the traditional duties of women - care of small children, care for the sick, cleaning houses, washing and ironing clothes, providing men with sexual satisfaction. While many Western women and men pay for care, domestic and sexual services, the transnational migrant, in her turn, often depends on someone in her country of origin for the domestic care of her own family. The sisters or aged parents who may be taking care of the children she has left behind are, in turn, supported by her long-distance earnings. In different ways, Hess's article on sex-workers affected by Europe's increasingly restrictive migration policies, and Hüwelmeier's on German nuns in North America, exemplify the fruitfulness of discussions on "the international division of labor" (Sassen 1983), "the ethnic division of reproductive labor" (Parreñas 2001) as well as feminist theory's abrogation of the binary opposition between productive and reproductive work, particularly when used within a longer historical perspective.

\section{Looking at both those who Migrate and those who Stay at Home}

When focus is redirected to the interplay between the migrants' life in Europe and the transnational family relations in both their country of origin and in the other countries of which they have become part, it also becomes possible for the scholar to go beyond the "nationalistic ideology" that otherwise easily leads to the analytical dichotomies of "at home, and abroad", "local and global", and the like (Amelina 2012).

Geographically separate worlds become interconnected; the narratives that tie together persons and events across national, linguistic and generational borders become the basis for experiences where the "home land" often consists of several different places (see Eastmond \& Åkesson 2007). The combined use of ethnographic and discourse-analytic methods and different theoretical perspectives interrogates the relationship between local integration and transnational networks. It is only by focusing on everyday life that one can study the role that kinship plays in transnational migration, allowing people to maintain a close community over time and at great distances. Only this, further, allows an understanding of how this is achieved in everyday practice. In this volume, ethnographic and experiential approaches provide important insights into the significance of these communities for their members. It becomes clear that migration is not a one-way process, destined for the terminus of integration within the frames of a nation state. Even after family relations are detached from their local context, they will often continue to organize relationships, senses of belonging, and material welfare. Narratives concerning who one is, as well as what it is that unites the family, including each family member's rights and duties, are maintained, adjusted and renegotiated in a process that includes both continuity and change. Family ties can thus be strengthened or weakened as they are invested with (partly) new meanings and emphasis.

Family and migration have been studied in many ways. But, regardless of focus - whether on monastic orders' symbolic mothers and daughters, the sex 
worker and her parents and children, or migrants' genealogies - there exist commonly shared practices which, in varying degrees, link together spatially scattered family members. These may be the exchange of economic and material resources with relatives who have remained in the country of origin, or the social care of children and old parents who were left behind, or the emotional support that can contribute to the family members' feeling of being valued simply for who they are. Today's adaptable and inexpensive means of communication can promote close contacts around everyday concerns and decisions. Different conditions for relatives in different places can also create tensions. An unequal division of power and resources and inevitable conflicts of interest necessitate constant renegotiation of roles and expectations across transnational space. Often, family ties that have worn thin over time can be picked up again, in a different context, later in life, or even by the next generation. An important insight provided by this broad empirical spectrum is that engagement with relatives on the other side of the globe does not conflict with the migrant's integration into the society of the receiving country. The relation between different places and generations is complex, and migrants take on different positions in the transnational space. These vary between and within families, and during an individual's life. They cannot be explained, in any simple way, by one-sided references to class, generation or gender. Especially Karen Körber's article shows the advantages of using narrative analyses of stories of migration to understand generation-specific constructions of family and of belonging in transnational spaces. It becomes clear that an intersectional analysis which includes the interaction of different power dimensions is more productive, even if it is significantly more difficult to carry out in practice.

The articles bring up many important questions concerning women, migration and transnational processes. Here, for once, the adult male has ended up in the margins. This raises new questions on the shifts in power made possible by women's mobility. Other questions can be asked about the children that migrant mothers often leave behind. Has their mothers' migration and employment abroad had any direct effects on the children's living conditions? How is the money that the mother sends back spent - on education, on bettering living space, and/ or consumption, and if so, of what and by whom? Körber's and Hess's articles call attention to the invisible work that is an undercurrent integral to today's welfare economy. The move away from migration studies' traditional focus on the immigrant male and his accompanying family allows us to see new patterns and strategies. Hopefully, this critical approach to transnational processes, international migration and gender will open up for more studies in which not only adults but children, those who migrate and those who are left behind, will both be seen and heard.

\section{References}

Agustín, Laura María 2007: Sex at the Margins: Migration, Labour Markets and the Rescue Industry. London: Zed.

Amelina, Anna (ed.) 2012: Beyond Methodological Nationalism: Research Methodologies for Cross-Border Studies. New York: Routledge.

Armine Ishkanian, Armine 2002: Mobile Motherhood: Armenian Women's Labor Migration in the Post-Soviet Period. Diaspora: A Journal of Transnational Studies 11:3, Winter 2002, 383-415.

Assal, Munzoul A.M. 2003: Beyond Labelling: Somalis and Sudanese in Norway and the Challenge of Homemaking. Diss. Bergen: Univ.

Bauman, Zygmunt 1998: Globalization: The Human Consequences. London: Polity.

Eastmond, Marita \& Lisa Åkesson (ed.) 2007: Globala familjer: transnationell migration och släktskap. Hedemora: Gidlund.

Ehrenreich, Barbara \& Arlie Russell Handschild (eds.) 2003: Global Woman: Nannies, Maids, and Sex Workers in the New Economy. 1st ed. New York: Metropolitan Books.

Frykman, Jonas \& Orvar Löfgren 1987: Culture Builders: A Historical Anthropology of Middle-Class Life. New Brunswick: Rutgers Univ. Press.

Lewitt, Peggy \& Nina Glick Schiller 2008: Conceptualizing Simultaneity: A Transnational Social Field Perspective on Society. In: Alejandro Portes \& Josh DeWind (eds.), Rethinking Migration: New Theoretical and Empirical Perspectives. New York: Berghahn Books, pp. 181-218.

Lindio-McGovern, Ligaya \& Isidor Wallimann (eds.) 2009: Globalization and Third World Women: Exploitation, Coping and Resistance. Farnham: Ashgate Pub.

Lindley, Anna 2010: The Early Morning Phone Call: Somali 
refugees' Remittances. New York: Berghahn Books.

Lindqvist, Beatriz 2007: Migrant Women in Ambiguous Business: Examining Sex Work across National Borders in the Baltic Region. In: Erik Berggren (ed.), Irregular Migration, Informal Labour and Community: A Challenge for Europe. Maastricht: Shaker, pp. 255-266.

Lindqvist, Beatriz 2008: Östersjöns Bangkok? En transnationell sexmarknad. In: Beatriz Lindqvist \& Mats Lindqvist, När kunden är kung: Effekter av en transnationell economi. 1st ed. Umeå: Boréa.

Lutz, Helma, Maria Teresa Herrera Vivar \& Linda Supik (eds.) 2011: Framing Intersectionality: Debates on a MultiFaceted Concept in Gender Studies. Farnham: Ashgate.

Mohanty, Chandra Talpade 2003: Feminism without Borders: Decolonizing Theory, Practicing Solidarity. Durham: Duke Univ. Press.

Parreñas, Rhacel Salazar 2001: Servants of Globalization: Women, Migration, and Domestic Work. Stanford, Calif.: Stanford University Press.

Povrzanović Frykman, Maja 2011: The Transnational Life of Objects: Material Practices of Migrants' Being and Belonging. Vetenskapsrådet. http://forskning.mah.se/id/ immafr.
Rosenthal, Gabriele \& Artur Bogner (eds.) 2009: Ethnicity, Belonging and Biography: Ethnographical and Biographical Perspectives. Berlin: Lit.

Sassen, Saskia 1983: Labor Migration and the New Industrial Division of Labor. In: June C. Nash \& María Patricia Fernández-Kelly (eds.), Women, Men, and the International Division of Labor. Albany: State Univ. of New York Press. Yeates, Nicola 2009: Globalizing Care Economies and Migrant Workers: Explorations in Global Care Chains. Houndmills, Basingstoke, Hampshire \& New York: Palgrave Macmillan.

Beatriz Lindqvist is Associate Professor of European Ethnology at Södertörn University, Sweden. She has published in the fields of migration, female ageing, diversity and education, and the commodification of sex in the Baltic Sea region. Her latest publication was edited together with Peter Strandbrink and Håkan Forsberg (2011): Tvära möten: om utbildning och kritiskt lärande (Södertörn Studies in Education) - a book on education and critical learning. Her current research focuses on activists in post-communist Lithuania. (beatriz.lindqvist@sh.se) 


\title{
IMMIGRATION - AND SECRETS
}

\author{
Karin Lützen
}

Despite this issue's title, Imagined Families, I did not see the famous quote by John Gillis: "We all have two families, one that we live with and another we live by. We would like the two to be the same, but they are not" (Gillis 1996: xv). To me, this sentence seems to say all there is to be said about our relationsship to families, in reality and in dream, and it has been an underlying theme in much of my own research.

All the articles in this issue look at "imagined families in mobile worlds", in which especially transnational families are the focus of research. It ties in well with my latest book from 2009: Mors hemmelighed (Mother's Secret: On the Track of a Jewish Immigrant History) and I will now explore some of my themes and discuss them in context with the articles in this issue.

My mother was French, born in Paris in 1923 and came to Denmark after the war to marry my Danish father. You could say that she thus founded a transnational family, since her parents stayed in France and she had to keep in touch with them, not through phone calls but through weekly letters. My grandmother died a year after my mother's wedding, so I never met her, but I knew her father, my "grandpère". My mother had no siblings, nor did we ever hear about any aunts or uncles or cousins. It seemed like my mother and her parents had appeared out of nowhere without any roots or kinship. This was a sharp contrast to my father who had a big family and whose mother's family had lived in our town for generations. On my paternal side of the family we were strongly rooted in Danish soil and we knew the history of the family.
Both my mother and grandfather were very proud of being French and I early on learned how brilliant France was: the language, the food, the climate, the culture - in short, that everything was better in France than in Denmark. As a very secular person my mother stressed the advantage of the separation of Church and State. Though she lived in Denmark and also seemed to like it, her cultural antenna was tuned in to France.

In 2004, six years after my mother's death, I started doing genealogical research. It suddenly occurred to me that I knew nothing about her parents nor her grandparents, and I had no clue as to where in France they were born. Imagine my surprise when I found out that her parents were not born in France at all but in Romania. It turned out that they were immigrants, and just had imagined themselves to be French. Even greater was my shock when I discovered that they were Jewish. My great-grandparents had fled Romania in 1899 to avoid the very bad conditions for Jews. The last surprise was to discover that my grandparents had lots of siblings and that my mother therefore had had many uncles, aunts and cousins. My mother was not without relatives as I had always believed. On the contrary, she had a whole world of kin.

Through more genealogical research, I managed to find some still living relatives. I asked them to tell me the story of my mother's family and help me solve the mystery of why they had been kept a secret. They said they had lost contact with my mother and her father after her marriage in Denmark, and since it was right after the war, when so many Jewish 
families were uprooted they did not really wonder about it.

I learned about the tragic histories of several families on both my grandmothers' and grandfathers' side during the Second World War. Several members of the family had been deported to Auschwitz, and not all had returned. My grandfather lost his younger brother, who perished in the concentration camp together with his wife and two small children: my mothers' uncle, aunt, and cousins. I wondered if it was this tragedy that had made my mother and grandfather bury their family history and never whisper a word about kin - and certainly never mention being Jewish.

But it was not as simple as that. Though my mother never lied about her background she created a past as she would have liked it to be, emphasizing parts of it and being silent about other parts. One can't say that she made up her family since she never talked about her kin, only about her parents. But she and they imagined themselves to be their own ideal of a secular, French, intellectual, middle-class family when in reality they came from a Jewish immigrant working-class family.

My mothers' cousin told me that in the interwar years my mother and her parents had been part of the big Yiddish-speaking Jewish Eastern European immigrant community in Paris. They had been members of Jewish mutual aid societies, my greatgrandparents were buried in the Jewish plot in the cemetery, they had all attended the Jewish holidays and my grandparents were married in a synagogueafter their civil marriage, as is the law in France. But my grandparents had stood out as something special among all their relatives. Everybody worked in the garment industry as tailors or seamstresses, which is typical for the Eastern European immigrants not only in France but also in England, the United States and Scandinavia.

Like immigrants from other countries such as the ones studied by Körber in this issue they had close networks and helped each other to jobs. But unlike the usual working migrants, these Eastern European Jews were refugees who had fled a country that treated them badly. It was not just one family who left but their relatives, including grandparent, aunts, uncles, and newborns. This means that there was nobody left "back there" to keep in touch with and it also means that these refugees were eager to embrace their new country as their homeland.

My great-grandfather had a little workshop at home and employed some garment workers. My grandfather had been trained as a tailor. But, as my mothers' cousin said, my grandfather had ambitions. He wanted to climb the social ladder, he wanted to get out of the narrowness of immigrant society with all its social control and enter the French middle class. And he managed. After his marriage to my grandmother - who was of course also a child of Romanian Jewish immigrants who were in the garment industry - he got a job as a salesman. $\mathrm{He}$ continued in the same trade, since it was fabric he was selling but at least he was no longer confined to a small workshop where they gossiped in Yiddish all day long. My mother's cousin also said that he was always elegantly dressed, spoke correct French, had refined manners and looked down upon his more shabby relatives with their deplorable accents.

My purpose in telling this - and in publishing the story in my book - is to show that my mother and her parents created an image of themselves as they wanted to be. They are in a way an imagined family, though they did not imagine their relatives to be something else. They knew all too well the family they, in Gillis' sense, lived with, but they created themselves anew. They are a splendid example of how modernity allows you to untie yourself from kin and to construct the life of your dreams.

I have no idea what the emotional costs of that liberation must have been and I am sure it was not without pain and solitude, but they must have found that their new life was worth it. Being Jewish was a burden, and during the war it was of course dangerous if people knew you were Jewish. I am sure my grandparents and my mother survived because they managed to pass themselves off as secular and French. But for them, being Jewish also meant being immigrant and working class and therefore they had to discard that part of their history.

In the introduction to this issue the authors write 
about tracing "the special significance accorded to 'memories and narratives' in diasporically dispersed families, as ways of enabling a shared understanding of family in circumstances of separation" (Körber \& Merkel, this issue, p. 7). In my family's case their "memories and narratives" certainly take on a special meaning since the memories are very carefully selected and the narratives are created so that they fit in with a self-created new life.

In my book I place the little history of my family in the context of the bigger history of Eastern European Jewish immigrants. I write more generally about the garment industry, mutual aid societies, traditions and daily life, application for French nationality and the painful story of how France has coped with the wartime Vichy government. I have also looked closely at my own interest in doing this genealogical research that I apparently have in common with many other people. Of course in my case there has been the discovery of this big secret which in itself has changed the genealogical research into a detective story.

But I - who have always subscribed to a constructionist view of the world, who believe that we have feet and not roots, who praise a modernity that makes it possible for us to get rid of our histories and to create our own lives - nonetheless became very sentimental every time I got in touch with a still living relative. And even if that relative had never met my mother or was as remotely related to me as for instance my grandmothers' mothers' younger brothers' youngest son, we felt an instant connection as soon as we met and still keep in touch as if we had been close relatives all our lives. Why have even I succumbed to the idea that you have something in common with distant kin? I still do not have the answer. I can only say that I am not just a clear-headed scholar but also a sentimental, ordinary person.

I do manage, however, to see the irony in genealogy as such. Genealogy attributes blood related kin enormous importance, even if we have never met them. There is also the self deception in believing that we are the direct descendants of our forefathers and foremothers, forgetting that we have to share them with several other relatives: We all have two parents, four grandparents, eight great-grandparents, sixteen great-great-grandparents and so on. If we go back ten generations, to around the year 1700, we theoretically will have about two thousand direct ancestors. If we go back twenty generations it will be as much as about two million. So which one to choose as the ancestor we see ourselves as direct descendants of? By writing this book I have paid great attention to my four Jewish great-grandparents who emigrated from Romania to France. But they ought not be more important to me than my Danish greatgrandparents, some of whom immigrated from Schleswig to the Faroe Islands to Greenland and then to Denmark. There seems to be a lot of mobility in my family.

Through genealogy we highlight blood related kin but downplay the importance other people have played in our lives. My mother and her parents created narratives where relatives had been written out of history and "families of choice" had been given great importance. Though my mother never mentioned her family beyond parents, she very often spoke of her friends from school with whom she formed lifelong friendships. She also fondly recalled neighbors she named aunt and uncle, whom she and her parents had chosen as their relatives. In that respect this story is not only about "transnational families" but also about "imagined families in mobile worlds" just like the theme of this issue.

\section{References}

Gillis, J. 1996: A World of their own Making: Myth, Ritual, and the Quest for Family Values. New York: Basic Books.

Lützen, K. 2009: Mors hemmelighed: På sporet af en jødisk indvandrerhistorie. Copenhagen: Gyldendal.

Karin Lützen, Ph.D., is a senior lecturer in history at Roskilde University. She has written books and articles on so diverse subjects as the history of homosexuality, the city, benevolence, and social reform. Her latest book is about Eastern European Jewish Immigration and she is now working on a history of silver manufacturing in Denmark 1880-1980. (lutz@ruc.dk) 


\title{
THE MATERIALITY OF THE IMAGINED FAMILY
}

\author{
Laura Stark
}

The volume Imagined Families draws welcome attention to recent developments in transnational families and their use of technologies. When Ulla $\mathrm{Vu}$ orela used the term "imagined families" in 2002, she was describing the different ways in which transnationally dispersed family networks with deep historical roots in the colonial period are perceived by kin group members themselves. In the present volume, the term "imagined" is intended more broadly to encompass how agencies, institutions and groups perceive the new possibilities offered to families by technology and mobility. The volume focuses on the discourses, images and political interests through which understandings of migration, mobility and family are socially constructed and reified. Its authors have drawn attention to important dimensions of these topics such as individual experience and motives, as well as ethical and emotional dilemmas. The point that all families and kinship relations are to some extent imagined is well taken, but as the authors point out, in many cases these most recent exercises in "imagining" the family do not necessarily result in innovation in new family forms and ideals. Although new technologies and new political alliances are sometimes utilized to disrupt older assumptions of the family as rooted or fixed in a geographic place, as in Timm's article, they are often used to shore up and protect conservative notions of the family: for instance the family as incomplete without biological children, as engaged in close daily interaction, or as characterized by a gendered division of labour in migration contexts, in which men are expected to migrate as wage labourers, but wom- en are expected to adopt a passive role as the accompanying spouse. ${ }^{1}$ Families may use new technologies and mobilities to expand their opportunities, but in some cases they do it simply to ensure the family's survival. It may be useful to see the family itself as a material "survival strategy" for individuals in societies where other social institutions and groupings offer little concrete support. Even in Europe, the current youth unemployment rate of over 20 percent highlights the continuing importance of the family as a survival net. It is to be hoped that this volume will generate new interest in how the family is currently understood and organized in the context of current challenges facing European societies.

As mentioned above, in each of the articles of this theme issue, the authors have chosen to critically examine the discursive dimensions of the transnational and/or technologically-assisted family and to bring attention to the nature and source of the rhetoric surrounding controversial family issues. In a volume of limited space, this is a worthy and justified aim. At the same time, however, it has meant that the material causes and consequences of these discourses remain under-problematized: we are given few insights into how individual agency is impacted by the nature of IVF technologies, or by the opportunities and limitations of mobile telephony and Skype, by economic conditions in Eastern Europe, or by the nature of prostitution in different contexts. We receive little sense of how familial ties, which have been of concern to the Catholic Church in Hüwelmeier's and Radkowska-Walkowicz's articles, historically have played a role in the Church's political 
aims, in other words in the expansion of its power through international networks of young migrating nuns, or as a bulwark against the intrusion into private lives of science and technology, which represent the main challenges to the Church's authority today. Moreover, if understood as a discursive creation alone, the mobile family becomes a difficult category for historical analysis. Without an account linking the discursive to the material, an adequate conceptualization of change is not possible.

For this reason, in my commentary I would like to take up the thematic thread of materiality which is only implicitly present in the articles in this theme issue. By materiality, I mean the physical and economic aspects of family organization and mobility, in other words livelihoods, resources and labour (other material aspects which I do not address are the body, disability, sexuality, health and illness). As an adherent of practice theory, I do not consider the material level of analysis to be logically prior to the level of social discourse, and it is important to refrain from essentializing such seemingly material facts as human reproduction or the global economy, which we experience primarily through rhetorical constructs. Particularly in the man-made environments in which most of us live today, material conditions do not reproduce themselves but are rooted in human practice.

I became interested in the issue of families and material resources when researching the first public discussion on Finnish rural women's rights, which took place in newspapers in the early 1860s (Stark 2011). This discussion in the press centered on socalled "home thievery", a common practice in which rural farm women covertly sold the products of the farm household (chiefly butter and grain) behind the farm master's back. With the proceeds of the sale, these farm wives and daughters then secretly bought consumer goods which were important in maintaining their social status as distinctive from lower-class servant women and laborers' wives. Although most who wrote to the press on this topic were educated social reformers and farm masters, several young farm women also discussed home thievery in their letters to the press. From the 64 let- ters published in Finnish-language newspapers on the topic between 1849 and 1901, it became clear to me that the issue of home thievery, while couched in moral terms as an evil, a vice and a "sickness", was recognized by many male and female writers to be rooted in the problems of unequal inheritance. Farm masters who wanted to save money needed their adult children to work on the farm without pay rather than work for other farms as paid servants (at which point the father would have had to hire servants from the outside to replace his children). The incentive intended to keep elder sons working on their birth farm was the promise of later inheriting the farm as a whole, but no such formal incentives were provided for daughters. Although farm daughters were legally entitled to receive half of the inheritance that their brothers received, in eastern Finland they often received nothing more than a few basic dowry goods when they married. Male writers from a wide range of backgrounds argued that without equal inheritance, women would never be motivated to work for the common good of the farm but would instead pilfer from the farm's storehouses to accumulate the goods they felt were rightfully theirs. Farm masters were reported as having traditionally turned a blind eye to the whole practice, yet in the early 1860s they began to speak out in condemnation of it. I concluded that home thievery had earlier been a tacit incentive to keep daughters laboring on the farm, one which did not undermine the public authority of the farm master as long as it remained hidden. However, when retail trade became legal in the countryside in 1859 , consumer goods came within reach of even those family members who had little opportunity to travel to distant markets. Since farm women sold pilfered goods secretly to the new rural shops through intermediaries, the practice of home thievery after 1859 quickly became expensive for farm masters, as "gallons of grain and pounds of butter began to slip away to the shops". ${ }^{2}$ Home thievery went from being a hidden incentive to a visible embarrassment for farm masters when farm women's wearing of the latest fabrics and high consumption of expensive coffee made it clear to others in the community that the family 
patriarch was unable to control the actions of his household members.

Although to explain human motives solely in rational economic terms would be reductionist and counterproductive, I was intrigued in my research by how a micro-level examination of material organization and resource distribution opened up new insights into the linkages between economic motives and cultural discourses on gender and family. Applied to the late modern family, a materialist perspective could, for example, explain why family members separate in the first place, why some members migrate while others stay behind, why some persons invest time and energy maintaining transnational family ties while others do not, or which specific family forms attract the greatest investment from their members. This question may be more easily answered for past societies, in which inheritance and socio-symbolic capital (honor and social prestige) were channeled to individuals primarily through roles occupied within the family. But are the present-day functions of the family so different? Inheritance, for instance, continues to be a highly pertinent issue for many Europeans, even for those who have left their birth communities, as anthropologist Nancy Konvalinka (2009, in press) suggests in her study of embodied inheritance. Konvalinka argues that persons can be shaped, by themselves and others, to maximize the use of the capital they inherit, when, for example, diplomats' children become diplomats or farmers' children become farmers. In the area of Spain she examines, economic conditions are pushing rural men to embody both their own and their sisters' inheritances. Daughters inherit land and thus control some of the land farmed by their brothers. A new implicit contract between brothers and sisters has recently appeared, however, in which brothers work hard on the farm to pay for their sisters' education, enabling their sisters to be more mobile than rural women used to be. As sisters become successful, move out of the rural context and marry non-farmers, they abstain from both using and selling the land they own, and brothers continue to use this land as if it were theirs.

While attention should be paid to the material and economic causes of family mobility or the family's use of new technologies, the material consequences of these practices should also be examined, and here there can be no a priori assumption that families and their strategies are characterized by solidarity and cohesion. In the 1980s and 1990s, anthropologists and socio-economists ${ }^{3}$ undertook a theoretical reexamination of the political and material factors underlying the family as an economic unit and began to peer into the "black box" of the household, in order to deconstruct the unitary socio-economic model of the family which had prevailed from the late 1950s to the late 1980s. ${ }^{4}$ Previously, the question of what went on inside the family and household with regard to work and resource allocation had been overlooked, and if resource allocation had been considered at all, it was assumed that resources and family members' tasks were rationally allocated by a benevolent household head seeking to maximize household utility for the common good. Later critiques defined the family and farm household instead as a locus of political struggle involving competing interests, negotiations over resources, and even conflict. Peering "inside" the family and household to perceive the internal conflicts therein would be a first step to understanding whether we can speak of "family" as a unitary concept in, for example, the issue of IVF in Poland: do wives and husbands view the concepts of childlessness, family, and reproductive rights in the same light? A non-unitary, material view of the household is also important for understanding the issue of female migration. Do we know, for instance, all the intrahousehold factors that push women to migrate? How are other family members affected materially by the migration of wives and mothers? Which relatives can make claims on female emigrant labourers' remittances and resources?

Material perspectives on the family may be even more pertinent for so-called developing countries. Economic restructuring and the withdrawal of the state from social and economic intervention, the explosive growth of the informal economy, and the influx of cheaply-made goods to low-income countries are resulting in severe unemployment and deprivation of basic needs. They are also contributing to a 
phenomenon which has been called "the feminization of obligation" within low-income countries, in which women must increasingly take on the primary burden for the survival of the family and dependent children, while men are becoming more likely to desert their families, withhold earnings from them or take the earnings of wives to fund self-oriented consumption (Chant 2006, 2008). Another consequence of relative income and labour structure differences among societies is the rise of global care chains (Hochschild 2000), in which, typically, a Filipina woman who migrates to work as a nanny in a high-income country uses her wages to employ someone to care for her children in Manila, who may in turn have her children cared for by another woman in the rural Philippines, who may depend on her older daughter to care for the younger siblings.

Families may in some sense be "imagined", but they have also always been mechanisms of resource distribution and the transmission of wealth. In many ways they also serve as structures which oversee the organization of labor. Families must always find ways to survive materially from day to day, which often means competing with other family groups. New forms of family arise when resources and livelihood opportunities themselves become redistributed in new ways in time and space (i.e. livelihood opportunities become seasonal or only available after lengthy training or education, or certain types of work become centered in particular geographical locations). These considerations give rise to questions such as: How do changes in the resources available to families lead to different re-imaginings of the family? How do new discourses surrounding the family affect the ways in which families manage their assets and strategize for continued survival?

\section{Notes}

1 See also Madianou and Miller's 2011 article in which they argue that for Filipina emigrant mothers, the immediacy of communication offered by mobile telephony has served to reinforce traditional notions of the mother as domestic caretaker who must continue to invest time and emotion in her children from a distance.

2 Oct. 19, 1888. Karjalatar no. 83, "Joensuusta. Maataloudellisetolotläänissämme”.
3 E.g., Collier \& Rosaldo (1981); Hartmann (1981); Sen (1983); Delphy (1984); Yanagisako \& Collier (1987); Guyer \& Peters (1987); Phillips (1989); Hart (1992, 1995); Moore (1992); Kabeer (1994); Agarwal (1997); Kandiyoti (1998).

4 E.g., Chayanov (1966). The unitary model of the household was made popular by the work of Gary Becker $(1965,1974,1981)$.

\section{References}

Agarwal, Bina 1997: Bargaining and Gender Relations: Within and Beyond the Household. Feminist Economics 3:1, 1-51.

Becker, Gary 1965: A Theory of the Allocation of Time. Economic Journal 299:75, 493-517.

Becker, Gary 1974: A Theory of Marriage: Part II. Journal of Political Economy 82:2, 11-26.

Becker, Gary 1981: A Treatise on the Family. Cambridge, Mass.: Harvard University Press.

Chant, Sylvia 2006: Re-thinking the "Feminization of Poverty" in Relation to Aggregate Gender Indices. Journal of Human Development 7:2, 201-220.

Chant, Sylvia 2008: Beyond Incomes: A New Take on the Feminisation of Poverty. In: Poverty in Focus: Gender Inequality. International Poverty Center, www.undp-povertycentre.org.

Chayanov, Aleksandr 1966: The Theory of Peasant Economy. Edited by Daniel Thorner, Basile Kerblay \& R.E.F. Smith. Homewood, IL: Richard Irwin.

Collier, Jane \& Michelle Rosaldo 1981: Politics and Gender in Simple Societies. In: Sherry Ortner \& Harriet Whitehead (eds.), Sexual Meanings: The Cultural Construction of Gender and Sexuality. Cambridge: Cambridge University Press.

Delphy, Christine 1984: Close to Home: A Materialist Analysis of Women's Oppression. London: Hutchinson.

Guyer, Jane \& Pauline Peters 1987: Conceptualizing the Household: Issues of Theory and Policy in Africa. Development and Change 18:2, 197-214.

Hart, Gillian 1992: Household Production Reconsidered: Production, Patronage and Gender Politics in Rural Malaysia. Rural Development 20:6, 809-823.

Hart, Gillian 1995: Gender and Household Dynamics: Recent Theories and their Implications. In: M.G. Quibria (ed.), Critical Issues in Asian Development. Hong Kong: Oxford University Press.

Hartmann, Heidi 1981: The Family as the Locus of Gender, Class, and Political Struggle: The Example of Housework. Signs 6:3, 366-394.

Hochschild, Arlie 2000: Global Care Chains and Emotional Surplus Value. In: Will Hutton, \& Anthony Giddens (eds.), On The Edge: Living with Global Capitalism. London: Jonathan Cape.

Kabeer, Naila 1994: Reversed Realities: Gender Hierarchies in Development Thought. London: Verso. 
Kandiyoti, Denise 1998: Gender, Power and Contestation: "Rethinking Bargaining with Patriarchy". In: Cecile Jackson \& Ruth Pearson (eds.), Feminist Visions of Development: Gender Analysis and Policy. London \& New York: Routledge.

Konvalinka, Nancy 2009: When Equal-Part Inheritance is not Equivalent: Gender and the Value of Land in a Spanish Village. In: P. Olsson \& H. Ruotsala (eds.), Gendered Rural Spaces. Helsinki: Finnish Literature Society.

Konvalinka, Nancy In press: Gender, Work and Property. Frankfurt: Campus Verlag.

Madianou, Mirca \& Daniel Miller 2011: Mobile Phone Parenting: Reconfiguring Relationships between Filipina Migrant Mothers and their Left-behind Children. New Media \& Society 13:3, 457-470.

Moore, Henrietta 1992: Households and Gender Relations: The Modelling of the Economy. In: S. Ortiz \& S. Lees (eds.), Understanding Economic Process. New York: University Press of America.

Phillips, Lynn 1989: Gender Dynamics and Rural Household Strategies. Canadian Review of Sociology and Anthropology 26:2, 294-310.

Sen, Amartya 1983: Economics and the Family. Asian Development Review 1:2, 599-634.

Stark, Laura 2011: The Limits of Patriarchy: How Female Networks of Pilfering and Gossip Sparked the First Debates on
Rural Gender Rights in the 19th-Century Finnish-Language Press. Helsinki: Finnish Literature Society.

Vuorela, Ulla 2002: Transnational Families: Imagined and Real Communities. In: D.F. Bryceson \& U. Vuorela (eds.), The Transnational Family: New European Frontiers and Global Networks. Oxford: Berg.

Yanagisako, Sylvia Junko \& Jane Fishburne Collier 1987: Toward a Unified Analysis of Gender and Kinship. In: Jane Fishburne Collier \& Sylvia Junko Yanagisako (eds.), Gender and Kinship: Essays Toward a Unified Analysis. Stanford: Stanford University Press.

Laura Stark is currently Professor of Ethnology at the University of Jyväskylä, Finland. Her research interests include modernization processes in nineteenth-century Finland, gender relations in Finnish agrarian society, nineteenthcentury concepts of body and self in rural Finland, as well as magic, witchcraft and folk religion. She is the author of The Limits of Patriarchy: How Female Networks of Pilfering and Gossip Sparked the First Debates on Rural Gender Rights in the 19th-Century Finnish-Language Press (2011, Finnish Literature Society).

(laura.stark@jyu.fi) 


\section{INSTRUCTIONS TO AUTHORS}

Ethnologia Europaea is a peer-reviewed journal that welcomes papers from European ethnology but also from social/cultural and historical anthropological perspectives as well as cross-disciplinary approaches in cultural analysis. Two issues are published yearly in a printed version as well as an online one.

To find out if your contribution fits in, you may start by e-mailing the two editors a short abstract or outline. To familiarize yourself with our profile, take a look at some recent issues. For a quick glance, go to the publisher's website www.mtp.hum.ku.dk/, choose English language and enter "Ethnologia Europaea" under "search". You will then be able to look at the table of contents of recent issues.

Authors of successfully published articles receive one copy of the journal and a pdf-file.

Submissions and format: Manuscripts (in English) should be sent to the two current editors as a computer file via e-mail. Papers should generally not exceed 12,000 words. Authors will be notified after the peer-review process about acceptance, rejection, or desired alterations.

British and American English can both be used, but consistently. For non-native English speakers it is important that the author has the final manuscript version language checked by a professional.

Too many grades of headings should be avoided. Long quotations should be marked by indentations and double line spacing above and below.

Abstract, keywords and author presentation: Five keywords as well as an abstract should accompany the manuscript. The abstract should be short (100125 words), outline the main features and stress the conclusions.

A short biography (two to three sentences) of the author should be included, describing title, position, interests of research and latest publications. A quick way of getting the format right for these items can be achieved by copying the style of a recent issue of Ethnologia Europaea\& I. Merkel (eds.): Ethnologia Europaea 42:2
Illustrations: You may supply suggestions for illustrations for the editors to choose from. For the final version the chosen illustrations with accompanying captions should be supplied on a cd, with the highest possible resolution. Desired positions of the illustrations should be marked in the text. Photographer or source should be mentioned in the captions. The author needs to secure publishing rights for all illustrations. The journal does not pay for illustration costs and authors using illustrations will be asked for a written statement about permissions.

Endnotes and references: Endnotes should be used sparingly; they are reserved for additional information or comments. If acknowledgements appear they should be placed in the first endnote.

References in the bibliography should have been used in the text. Bibliographic references in the text are given as (Hobsbawm \& Ranger 1983; Shaw $1995,2000)$. In the bibliography the following system is used:

For journals or composite works:

Falk, P. \& C. Campbell 1997: Introduction. In: P. Falk \& C. Campbell (eds.), The Shopping Experience. London: Sage.

Shore, C. 1999: Inventing Homo Europaeus: The Cultural Politics of European Integration. Ethnologia Europaea 29:2, 53-66 (or Ethnologia Europaea, vol. 29 , no. 2, pp. 53-66).

\section{For books:}

Bauman, Z. 2000: Liquid Modernity. Cambridge: Polity Press.

Riggins, S.H. (ed.) 1997: The Language and Politics of Exclusion: Others in Discourse. London: Sage Publications.

\section{For websites:} www.un.org/News/. Accessed April 5, 2008. 


\section{INSTRUCTIONS TO AUTHORS}

Ethnologia Europaea is a peer-reviewed journal that welcomes papers from European ethnology but also from social/cultural and historical anthropological perspectives as well as cross-disciplinary approaches in cultural analysis. Two issues are published yearly in a printed version as well as an online one.

To find out if your contribution fits in, you may start by e-mailing the two editors a short abstract or outline. To familiarize yourself with our profile, take a look at some recent issues. For a quick glance, go to the publisher's website www.mtp.hum.ku.dk/, choose English language and enter "Ethnologia Europaea" under "search". You will then be able to look at the table of contents of recent issues.

Authors of successfully published articles receive one copy of the journal and a pdf-file.

Submissions and format: Manuscripts (in English) should be sent to the two current editors as a computer file via e-mail. Papers should generally not exceed 12,000 words. Authors will be notified after the peer-review process about acceptance, rejection, or desired alterations.

British and American English can both be used, but consistently. For non-native English speakers it is important that the author has the final manuscript version language checked by a professional.

Too many grades of headings should be avoided. Long quotations should be marked by indentations and double line spacing above and below.

Abstract, keywords and author presentation: Five keywords as well as an abstract should accompany the manuscript. The abstract should be short (100125 words), outline the main features and stress the conclusions.

A short biography (two to three sentences) of the author should be included, describing title, position, interests of research and latest publications. A quick way of getting the format right for these items can be achieved by copying the style of a recent issue of Ethnologia Europaea\& I. Merkel (eds.): Ethnologia Europaea 42:2
Illustrations: You may supply suggestions for illustrations for the editors to choose from. For the final version the chosen illustrations with accompanying captions should be supplied on a cd, with the highest possible resolution. Desired positions of the illustrations should be marked in the text. Photographer or source should be mentioned in the captions. The author needs to secure publishing rights for all illustrations. The journal does not pay for illustration costs and authors using illustrations will be asked for a written statement about permissions.

Endnotes and references: Endnotes should be used sparingly; they are reserved for additional information or comments. If acknowledgements appear they should be placed in the first endnote.

References in the bibliography should have been used in the text. Bibliographic references in the text are given as (Hobsbawm \& Ranger 1983; Shaw $1995,2000)$. In the bibliography the following system is used:

For journals or composite works:

Falk, P. \& C. Campbell 1997: Introduction. In: P. Falk \& C. Campbell (eds.), The Shopping Experience. London: Sage.

Shore, C. 1999: Inventing Homo Europaeus: The Cultural Politics of European Integration. Ethnologia Europaea 29:2, 53-66 (or Ethnologia Europaea, vol. 29 , no. 2, pp. 53-66).

\section{For books:}

Bauman, Z. 2000: Liquid Modernity. Cambridge: Polity Press.

Riggins, S.H. (ed.) 1997: The Language and Politics of Exclusion: Others in Discourse. London: Sage Publications.

\section{For websites:} www.un.org/News/. Accessed April 5, 2008. 
Though a seemingly stable concept in ethnological work, "family" as a lived reality took and takes on innumerable forms shaped by economic pressures, mobility and attendant social transformations, and biotechnical interventions. The case studies in this special issue focus on the ways in which social actors seek to concretize as well as control what family could or should be.

While (bio-)technological innovation proves vital to fulfill traditional imaginaries of a nuclear family, communication technology is a key to keep transnationally situated families in contact. Still, transnational work opportunities conflict with traditional imaginaries of the wholesome families and impact particularly women seeking to cross both borders and established family norms. Popular genealogy as a hobby and passion uncovers evidence that counters established narratives: instead of long-term sedentary family lineages, evidence of migration muddies the waters. Family metaphor, finally, serves, in one of the case studies, as vocabulary to materialize imaginary kinship ties among nuns. The five case studies are complemented by four commentaries, exploring paths along which these themes can be developed further. 